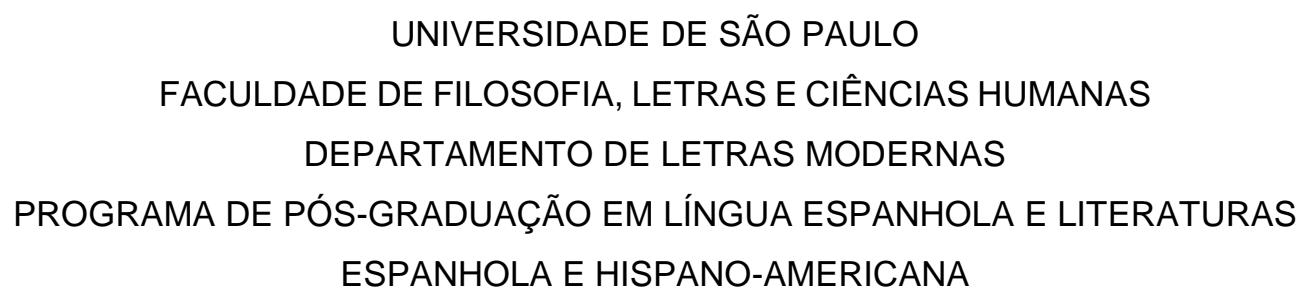

Hijo de Ladrón, de Manuel Rojas: Uma forma do Bildungsroman.

Versão corrigida 
UNIVERSIDADE DE SÃO PAULO

FACULDADE DE FILOSOFIA, LETRAS E CIÊNCIAS HUMANAS

DEPARTAMENTO DE LETRAS MODERNAS

PROGRAMA DE PÓS-GRADUAÇÃO EM LÍNGUA ESPANHOLA E LITERATURAS

ESPANHOLA E HISPANO-AMERICANA

GILDNÉIA RAMOS BLOHEM SANTOS

Hijo de Ladrón, de Manuel Rojas: Uma forma do Bildungsroman.

Versão corrigida

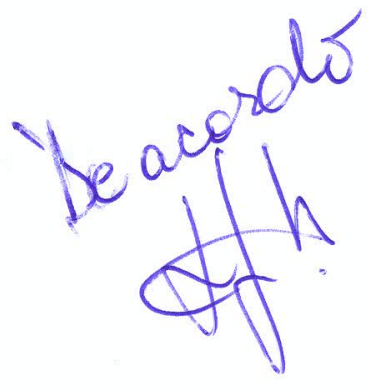

São Paulo

2013 


\author{
UNIVERSIDADE DE SÃO PAULO \\ FACULDADE DE FILOSOFIA, LETRAS E CIÊNCIAS HUMANAS \\ DEPARTAMENTO DE LETRAS MODERNAS \\ PROGRAMA DE PÓS-GRADUAÇÃO EM LÍNGUA ESPANHOLA E LITERATURAS \\ ESPANHOLA E HISPANO-AMERICANA
}

\title{
Hijo de Ladrón, de Manuel Rojas: Uma forma do Bildungsroman.
}

\author{
GILDNÉIA RAMOS BLOHEM SANTOS
}

Dissertação apresentada ao programa de Pós -Graduação em Língua Espanhola e Literaturas Espanhola e Hispano-Americana do Departamento de Letras Modernas da Faculdade de Filosofia, Letras e Ciências Humanas da Universidade de São Paulo, para obtenção do título de Mestre em Letras.

Versão corrigida.

De acordo,

Orientadora: Profa. Dra. Laura Janina Hosiasson

\section{São Paulo}

2013 
Autorizo a reprodução e divulgação total ou parcial deste trabalho, por qualquer meio convencional ou eletrônico, para fins de estudo e pesquisa, desde que citada a fonte.

Catalogação na publicação

Serviços de Biblioteca e Documentação

Faculdade de Filosofia, Letras e Ciências Humanas da Universidade de São Paulo

PCD

Blohem S., Gildnéia Ramos

Hijo de Ladrón, de Manuel Rojas: Uma forma do Bildungsroman / Gildnéia Ramos Blohem Santos; orientadora Laura Janina Hosiasson. São Paulo, 2013

125 p.: il.

Dissertação (Mestrado) - Faculdade de Filosofia, Letras e Ciências Humanas da Universidade de São Paulo, 2013.

1. Rojas, Manuel 1896-1973. 2. Hijo de Ladrón. 3. Literatura Chilena. 
BLOHEM S., Gildnéia Ramos. Hijo de Ladrón, de Manuel Rojas: Uma forma do Bildungsroman. Dissertação (mestrado). Universidade de São Paulo, São Paulo, 2013.

Dissertação apresentada ao programa de Pós -Graduação em Língua Espanhola e Literaturas Espanhola e Hispano-Americana do Departamento de Letras Modernas da Faculdade de Filosofia, Letras e Ciências Humanas da Universidade de São Paulo, para obtenção do título de Mestre em Letras.

Aprovada em

Banca Examinadora

Prof. Dr.

Instituição:

Assinatura:

Prof. Dr.

Instituição: Assinatura:

Prof. Dr.

Instituição: Assinatura: 
Aos meus pais, por todo o amor e abnegação, através dos quais me tornei um ser humano completo. 


\section{AGRADECIMENTOS}

À Dra. Laura Janina Hosiasson, que nos anos de convivência, muito me ensinou, contribuindo para meu crescimento científico e intelectual.

À Dra. Maria Teresa Cristófani Barreto, graças à qual cheguei ao autor Manuel Rojas.

À minha irmã do coração, Adriana Martins Simões, pela atenção e apoio durante o processo de definição e orientação.

Ao meu irmão, Uildson Ramos Blohem, que sem saber, me introduziu de modo irremediável na vida acadêmica.

Aos melhores pais do mundo, para os quais sempre tentei fazer as escolhas corretas.

Ao meu marido, Ramon, por todo o seu amor e suporte demonstrados nesses anos de alegrias juntos.

À minha filha, que já antes de vir ao mundo, me impelia a ser uma pessoa melhor.

A Deus, a quem devo toda a minha vida. 
Tudo isto provei-o pela sabedoria; eu disse: Sabedoria adquirirei; mas ela ainda estava longe de mim.

Salomão (Eclesiastes 7: 23) 


\section{RESUMO}

BLOHEM S., Gildnéia Ramos. Hijo de Ladrón, de Manuel Rojas: Uma forma do Bildungsroman. Dissertação (mestrado). Faculdade de Filosofia, Letras e Ciências Humanas. Universidade de São Paulo, São Paulo, 2013.

Este trabalho inicia-se com a apresentação do autor, sua importância literária e seu contexto histórico, e tem por objetivo analisar a trajetória de Aniceto Hevia, narrador autodiegético do romance Hijo de Ladrón, de Manuel Rojas. O romance se articula em torno aos problemas e experiências das classes socialmente marginalizadas e dos conflitos sociais e econômicos do proletariado no Chile entre o fim do século XIX e o início do XX. Observaremos o Bildungsroman Clássico, gênero discursivo originado na Alemanha, em meio à difusão das ideias burguesas de fins do século XVIII. O intuito aqui é observar como o livro de Rojas, inscrito em um contexto afastado pelo tempo, espaço e circunstâncias sócio econômicas do paradigma do Bildungsroman, mantém afinidades de ponto de vista e de conteúdo em relação ao gênero clássico em questão.

Palavras-chave: literatura hispano-americana; gênero Bildungsroman; Manuel Rojas. 


\section{RESUMEN}

BLOHEM S., Gildnéia Ramos. Hijo de Ladrón, de Manuel Rojas: Una forma de Bildungsroman. Dissertação (mestrado). Faculdade de Filosofia, Letras e Ciências Humanas. Universidade de São Paulo, São Paulo, 2013.

Este trabajo comienza con la presentación del autor, su importancia literaria y contexto histórico, y su objetivo es analizar la trayectoria de Aniceto Hevia, narrador autodiegético del libro Hijo de Ladrón, de Manuel Rojas. La trama de la novela ocurre entre personajes marginalizados en Chile a partir del fin del siglo XIX hasta el inicio del XX. Observaremos el Bildungsroman Clásico, género discursivo originado en Alemania, en el centro de la difusión de las ideas burguesas de fines del siglo XVIII. El objetivo aquí es observar como el libro de Rojas, inscrito en un contexto alejado por el tiempo, espacio y circunstancias socio económicas del paradigma del Bildungsroman, mantiene afinidades de punto de vista y de contenido con relación al género clásico en cuestión.

Palabras clave: literatura hispano-americana; género Bildungsroman; Manuel Rojas. 


\section{ABSTRACT}

BLOHEM S., Gildnéia Ramos. Hijo de Ladrón by Manuel Rojas: A form of the Bildungsroman. Master's degree dissertation. Faculdade de Filosofia, Letras e Ciências Humanas. Universidade de São Paulo, São Paulo, 2013.

This work begins with the introduction to the author, to his literary importance as well as to his historical context, and it has the purpose of analyzing Hevia Aniceto's pathway, who is the autodiegetic narrator in the novel Hijo de Ladrón by Manuel Rojas. The novel revolves around the problems and the experiences lived by the socially marginalized classes, and also around the social and economic conflicts experienced by the proletariat in Chile from the end of the $19^{\text {th }}$ Century to the beginning of the $20^{\text {th }}$ Century. We will observe the Classic Bildungsroman, which is a discursive gender originated in Germany in the midst of the dissemination of bourgeois ideas from the end of the $18^{\text {th }}$ Century. Our purpose here is to observe how Rojas' book, which is inserted in a context kept away by time, space and socio-economic circumstances of the Bildungsroman paradigm, maintains content and viewpoint affinities in relation to the classical gender in question.

Key-words: Hispanic American literature; Bildungsroman gender; Manuel Rojas. 
- Imagem no 1 - Colégio Cardenal Cisneros..........................................p.110

- Imagem no 2 - Presídio de Sierra Chica............................................... 111

- Imagem no 3 - Presídio de Ushuaia.....................................................112

- Imagem no 4 - Soldados da infantaria de Felix Uriburu.....................p.113

- Imagem no 5 - Presos trabalhando em Ushuaia...............................p.114

- Imagem no 6 - Conventillo oํ1........................................................115

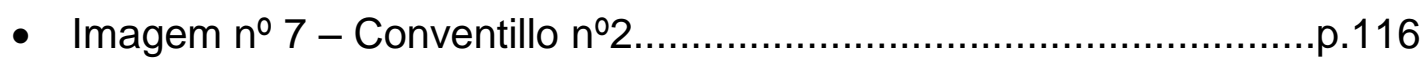

- Imagem no 8 - Conventillo no3..........................................................117

- Imagem no 9 - Pasaje Quillota ……………….................................118

- Imagem no 10 - Calle Castillo entre 1890 e 1901 .............................p.119 


\section{SUMÁRIO}

INTRODUÇÃO

1. VISÃO SOCIAL E LITERATURA ENTRE FINS DO XIX E INÍCIO DO XX ..............................15

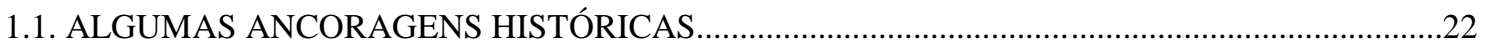

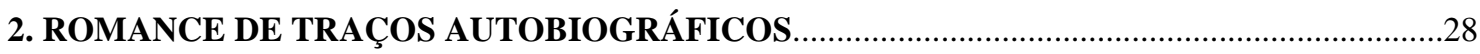

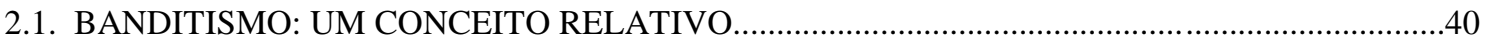

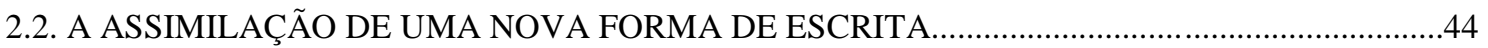

3. GÊNEROS AFINS (DIÁLOGO COM O GÊNERO PICARESCO).....................................................49

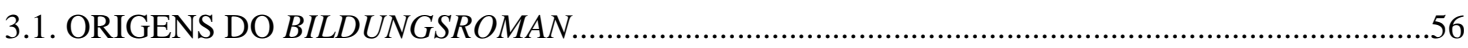

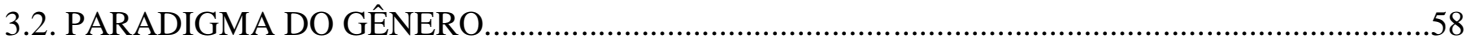

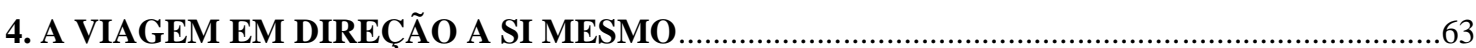

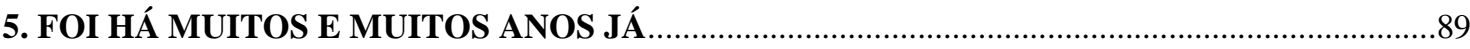

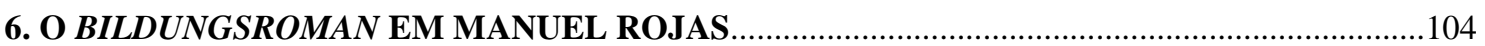

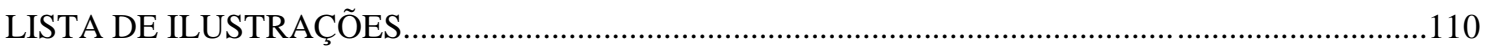

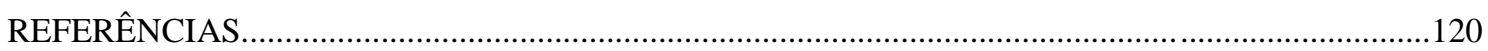




\section{INTRODUÇÃO}

O presente trabalho constitui-se como uma sistematização das pesquisas realizadas até o momento sobre o livro Hijo de Ladrón, publicado em 1951, do autor chileno Manuel Rojas. Espero que suas páginas reflitam os esforços empreendidos para destacar os recortes e suportes teóricos que utilizei para apontar os encaminhamentos operados na estruturação da análise. Nessa direção, apresenta-se divido em seis partes. A primeira procura situar os acontecimentos históricos e sociais que se desenrolaram entre o final do século XIX e o início do XX no Chile.

A segunda consiste em tratar dos traços autobiográficos presentes no romance Hijo de ladrón (1951) e como se dá a entrega dos mesmos a partir do ponto de vista narrativo. O autor, Manuel Rojas, conta-nos como, de diversas maneiras, suas experiências pessoais ingressaram em seus escritos e admite que, mesmo quando seus personagens não são diretamente espelhados em pessoas reais, trata-se de "composiciones o desfiguraciones".

Depois, realizamos a apresentação dos gêneros Picaresca e Bildungsroman, com a definição de ambos os conceitos e as origens paradigmáticas do Bildungsroman como gênero textual. Observamos como o romance picaresco, originado no século $\mathrm{XVI}$, pertence a uma linhagem de tradição narrativa que dialoga com o Bildungsroman.

Após a apresentação do gênero Bildungsroman, observarei como se dão as transformações operadas no protagonista desde o momento que deixa o lar em Buenos Aires, até quando trava conhecimento com personagens que funcionarão como mentores, e como isso acontece através da narrativa em primeira pessoa.

Também observaremos como se dá a temporalidade ligada à rememoração, ou seja, com aspectos ligados à viagem no tempo, que têm relação direta com a narrativa em primeira pessoa e a memória como construção política.

Por fim, observaremos como o livro de Rojas se inscreve, apesar de suas particularidades e especificidades no paradigma clássico alemão. 
Encontrei hoje em ruas, separadamente, dois amigos meus que se haviam zangado um com o outro. Cada um me contou a narrativa de por que se haviam zangado. Cada um me disse a verdade. Cada um me contou as suas razões. Ambos tinham razão. Não era que um via uma coisa e outro outra, ou que via um lado das coisas e outro um lado diferente. Não: cada um via as coisas exatamente como se haviam passado, cada um as via com um critério idêntico ao do outro, mas cada um via uma coisa diferente, e cada um, portanto, tinha razão.

Fiquei confuso desta dupla existência da verdade.

Fernando Pessoa 


\section{VISÃO SOCIAL E LITERATURA ENTRE FINS DO XIX E INÍCIO DO XX}

Até 1951, no Chile, os traços predominantes na literatura gravitavam no âmbito do criollismo - movimento artístico literário surgido na América Hispânica em fins do século XIX. Entre suas características encontrava-se um traço de denúncia social como resposta ao menosprezo que as populações campesinas sofriam, o que, por sua vez, decorria da tendência de que somente as cidades eram valorizadas, vistas como as grandes responsáveis pelo desenvolvimento nacional.

Cedomil Goic, em seu estudo sobre o romance hispano-americano, explica que a geração de 1912 (também chamada de mundonovista) deu crescente importância ao meio natural, e à paisagem como elemento de diferenciação da realidade americana em relação à europeia. Deste modo, criou-se uma forte tendência nativista, resultante de um renovado nacionalismo literário. Neste tipo de romance, a paisagem figurava como o princípio de convergência, reunindo características de situações, personagens e cenário natural e representando a luta do homem com o meio - avassalador -, que anula sua liberdade e determina sua existência através de funestos poderes (GOIC, 1973, pp.38-39). O criollismo alcançou o apogeu no início do século $X X$, e tinha, portanto, o intuito de compreender o Chile como uma nação que passava a ter identidade própria. Para Mariano Latorre, considerado o grande mestre do movimento, a escrita devia tratar de dignificar o homem (herói) em relação ao meio em que estava inserido, pois segundo ele "el drama sigue siendo la lucha del hombre con el medio, por lo menos el drama chileno, el drama americano(...)Gaucho en Argentina y Uruguay, huaso en Chile, este héroe de la paz debía substituir al héroe histórico, al soldado de la emancipación." (LATORRE, 1953, pp. 41, 80) Os limites do criollismo são também comentados pelo crítico peruano José Miguel Oviedo, para quem as obras do movimento, a despeito de uma grande simpatia humana e um sentido de cor local proporcionaram mais topografia que ficção, com certas tonalidades poéticas, mas sem ter sido capazes de criar quadros de tensão narrativa: "más 
que capítulos - diz ele - lo que tenemos son escenas, cuadros vivos: el amanecer, la aldea, la sequía, la vendimia..." (OVIEDO, 1988, pp. 25-34)

Deste modo, o que mais caracterizou os escritores que aderiram ao criollismo parece ter sido esse desejo de transformar a "chilenidade" em entidade estética de valor universal. Latorre e os que partilhavam de suas ideias foram importantes num cenário de época em que o país via-se fortemente influenciado pela preponderância estrangeira. Não obstante a importância do movimento para a literatura nacional chilena, os seus cultivadores, por vezes empolgados pela admiração da natureza, fizeram do camponês e seu entorno rural seu tópico principal, e com isso evidenciavam a fauna e a flora em detrimento dos personagens e seus conflitos narrativos. Para o especialista inglês William Rowe, em Manuel Rojas podemos observar a ruptura, pois ele "articula los códigos lingüísticos y sociales de los sectores marginados a tal punto que el discurso del criollismo queda desplazado" (ROWE, 1994, p. 713). Certa vez, o crítico literário da Universidade do Chile, Antonio Avaria de la Fuente, em uma entrevista com Manuel Rojas para a revista Árbol de Letras em abril de 1968, comentou o fato de o autor evitar a reprodução fonética de sua linguagem, ou seja, o naturalismo linguístico, e Rojas explicou o seguinte:

Soy enemigo de ese criollismo. No tiene ninguna ventaja. Lo que importa no es cómo habla un personaje, sino lo que dice. Tanta entonación local lleva a una literatura ininteligible para otras regiones o países. La transcripción fonética me parece más bien cosa de filólogos (AVARIA, 1968, p. 01).

Além desses fatores citados em relação ao criollismo, em Hijo de Ladrón já se observa que, apesar de que a matéria contada seja real o modo de contar não é típico do realismo, pois não há sequência narrativa, uma vez que o narrador segue o fluxo de suas evocações (IMBERT, 2005, pp. 116-117). Isso ocorre porque Rojas, ao invés de tomar como referenciais diretos as fontes hispano-americanas de sua época, tem nas raízes de seus procedimentos nomes como William Faulkner, Marcel Proust e James Joyce.

Hijo de Ladrón narra a história e os conflitos existenciais do jovem pintor de paredes, Aniceto Hevia, recém saído da adolescência, num espaço que se 
articula entre o Chile e a Argentina. Aniceto nasce em um lar no qual a mãe é uma dona de casa e o pai, um ladrão, descrito pelo narrador como "sobrio, tranquilo, económico y muy serio en sus asuntos" (HL, p. 11) ${ }^{1}$. A mãe aparece no livro como viga de sustentação para os filhos, no que diz respeito aos valores éticos, e por causa dela, a família consegue se manter dentro de uma aparência nos moldes pequeno burgueses, sem que os vizinhos desconfiem do ofício do pai . O protagonista nasce em Buenos Aires, onde passará sua infância; na adolescência, após a morte da mãe seguida da prisão do pai e diante da dissolução da família, ele viaja ao Chile, onde permanecerá até o final da narrativa.

Se, por um lado, Hijo de Ladrón foi escrito numa época em que o debate em torno do pensamento psicanalítico já tinha se consolidado, a temática do livro de Rojas instiga por remontar ao gênero romântico do Bildungsroman. Neste trabalho tentaremos demonstrar que conceitos como esse e temáticas filosóficas contemporâneas ao autor, como o existencialismo e a psicanálise, podem entrelaçar-se na análise do estudo da obra, no contexto de um Chile recém moderno.

A hipótese que aqui se desenvolve é a de que o romance, apesar de duplamente afastado (pelo tempo e pelo espaço) do paradigma do Bildungsroman clássico, desenvolve características deste gênero literário e, embora não se inscreva ipsis litteris no conceito convencional, aponta para uma evolução do gênero, dado o transcurso diferenciado histórico-social em que se desenvolve. Ao nosso ver, apesar de possuir características autobiográficas e se desenvolver em camadas baixas da sociedade, Hijo de Ladrón não se insere nos moldes da picaresca, e sim do Bildungsroman. Todavia, há motivos para crer que o livro de Rojas não se inscreve exatamente no paradigma clássico alemão, e por isso exibe a evolução do gênero, ao se confrontar com as definições tradicionais. A própria grande memória sobre a qual se estrutura a narrativa diverge do Bildungsroman clássico.

Existe uma unidade no relato de Aniceto Hevia, mas que responde à associação de ideias dentro da memória do narrador principal. Armand F.

\footnotetext{
${ }^{11}$ Por razões de economia de linguagem, sempre que for citado o romance Hijo de Ladrón, serão usadas as iniciais $H L$.
} 
Baker - pesquisador de literaturas de língua espanhola pela Universidade de lowa e pela Universidade de Nova lorque em Albany - escreveu o interessante artigo "Hacia uma nueva novela: estudio del tiempo en Hijo de Ladrón, de Manuel Rojas", que seguiremos de perto para explicar a opção por este autor.

Após a segunda metade do século XX operam-se transformações substanciais na técnica narrativa do romance hispano-americano como podemos observar, por exemplo, em Manuel Rojas, pois a maioria dos autores da primeira metade do século não haviam abandonado completamente a estrutura linear do século passado.

Baker explica que a tendência em direção a uma crescente liberdade na estrutura do romance começa a partir do início do século XX, na Europa com Proust e Joyce, e na América Latina com escritores tais como Teresa de la Parra, Eduardo Barrios, María Luisa Bombal, Eduardo Mallea, entre outros. O interesse nascente em torno da psiquê humana produz algumas inovações no tratamento do tempo e permite um pouco mais de flexibilidade na organização dos fatos. Mas a narração quase nunca se situa dentro de regiões mais íntimas da consciência ao longo de uma obra inteira, nem se aparta definitivamente de um conceito de tempo cronológico. Depois, observam-se as obras de autores que também se expandem na narrativa psíquica, na direção do fluxo de consciência, tais como Virginia Woolf, William Faulkner e Alejo Carpentier. Após a segunda metade do século, entre os autores que caminham de modo decisivo nesta direção, na América Latina, encontra-se Manuel Rojas.

A seguir Baker faz interessante distinção entre o que se pode chamar 'fábula' e 'sujet', dentro destes novos procedimentos narrativos:

(...) aunque esto no signifique una libertad completa en la disposición de los hechos, lo que sí quiere decir es que la trama de la novela, como ha sido concebida a través de la historia del género, ha de desaparecer. En la novela contemporánea hay una diferencia enorme entre la "fábula" - la secuencia temporal-causal que refiérase como se refiera, es el "cuento," - o el tema del cuento - y el "sujet" - la estructura narrativa", o sea, la presentación artísticamente dispuesta de los hechos. ${ }^{2}$ Esto quiere decir que la mente del narrador ya organiza los sucesos de un modo que corresponde a su propia

\footnotetext{
${ }^{2}$ La definición de los términos .fábula. y .sujet. está tomada del libro de René Wellek y Austin Warren, Theory of Literature (New York, Harcourt, Brace \& World, 1956), p. 218.
} 
visión psíquica del tiempo y de la realidad, y no necesariamente al orden que éstos tuvieron cuando ocurrieron. (BAKER, p. 2)

Observa-se, como se vê, uma clara discrepância entre a 'fábula' e o 'sujet' em Hijo de Ladrón, e com isso, a ruptura definitiva desta obra com a tradição do romance realista. No livro, considerado como a obra-prima de Rojas, o tempo da fábula contempla um período de aproximadamente vinte anos, enquanto o tempo narrativo abarcado pelo sujet é de somente uns poucos dias. E Baker arremata que "es esta dislocación enorme entre fábula y sujet, lo que ha resultado en la nueva forma de la novela que consideramos aquí; es, como un crítico lo ha denominado, "una continua y formidable digresión" en el tiempo." 3 (Ibidem, pp. 2-3)

Os fatos em Hijo de Ladrón ocorrem no Chile, entre o final do século XIX e começo do XX, segundo o próprio Manuel Rojas, antes de 1913, já que o próximo romance, que trataria da vida de Aniceto Hevia até os vinte e cinco anos - Mejor que el vino - desenvolve-se entre os anos de 1913 e 1921. (ROJAS, 2008, p. 199). Poderíamos dizer que o protagonista se apresenta como um produto do seu século e das idiossincrasias histórico-sociais do país na época. O romance se articula em torno aos problemas e experiências das classes socialmente marginalizadas e dos conflitos sociais e econômicos do proletariado no Chile, no início do século XX, experiências essas que o autor vivenciou, ele próprio, de perto.

Segundo o historiador chileno Osvaldo Silva Galdames, a partir das últimas décadas do século XIX, quando o Chile começava a se consolidar industrialmente, tornaram-se um problema social as condições de vida do proletariado (GALDAMES, 1999, pp. 212-278). Certamente, a pobreza e as desigualdades sociais, oriundas dos séculos da Colônia, não surgiram no país nesse período, mas não somente elas não tinham desaparecido como se acentuaram na realidade do Chile independente. Desde meados do século XIX, já existia no país uma conjuntura entre a mineração e a indústria - com as empresas de extração do carvão e do cobre -, mas seria depois da Guerra do

\footnotetext{
${ }^{3}$ Norman Cortés Larrieu, “Hijo de ladrón de Manuel Rojas: Tres formas de inconexión en el relato," en Estudios de lenguaje y literatura como humanidades (Santiago de Chile, 1960), p. 113.
} 
Pacífico (1879-1883), através da incorporação das ricas regiões salitreiras de Tarapacá y Antofagasta que essa relação se tornaria mais estreita. De acordo com Bernardo Subercaseaux, em 1880 o salitre representava $26 \%$ das exportações; em 1895, chegava a $60 \%$ e gerava mais da metade das rendas da nação. Com isso, aumentaram também as importações de produtos supérfluos. Essa movimentação econômica trouxe um desenvolvimento da infraestrutura urbana e de transportes, ao longo de um trecho de $750 \mathrm{~km}$ de deserto: "lejos de constituir un enclave aislado que inhibió la expansión del capitalismo en Chile, el salitre fue un factor fundamental en su desarrollo, florecimiento y modernización" (SUBERCASEAUX, 1984, p. 91).

Com todo esse desenvolvimento urbano em processo, aumentou a necessidade de serviços técnicos especializados de pedreiros, carpinteiros, pintores, costureiras, sapateiros, motoristas de bondes, entre outros. As atividades industriais também demandavam mão de obra, em grande parte, rural. Esses aspectos contribuíram para o desenvolvimento da economia de mercado e uma maior integração da economia chilena com o capitalismo e o mercado mundiais.

Ainda na esteira de Subercaseaux, nesse processo, os benefícios foram gerados basicamente para as elites, em detrimento das camadas populares, produzindo assim, profundos desequilíbrios internos. Dia a dia podia-se observar o engrossamento das fileiras de proletários urbanos em cidades como Santiago, Valparaíso, Concepción e lquique, que recebiam salários vergonhosos e eram submetidos a condições miseráveis de moradia, higiene e alimentação.

De acordo com Galdames, pode-se observar que a partir de 1880 puseramse em marcha uma série de movimentos sociais que tentavam denunciar as más condições de vida dos obreiros, como resultado da exploração de que eram vítimas, em um contexto econômico capitalista já plenamente consolidado, marcado não somente pela industrialização, como também por um processo de urbanização descontrolado que agravava as más condições de vida do trabalhador urbano. Por um lado, erguia-se uma classe dirigente cega diante dos problemas e queixas do povo, e por outro, uma classe trabalhadora cansada de esperar que o Estado oferecesse alguma solução para suas demandas. Esses movimentos transformaram a questão social em um 
problema que afetaria não somente os trabalhadores, mas o país como um todo. Exemplos de tendências políticas que se fortaleceram nesses anos foram os grupos socialistas e anarquistas, impulsionados por setores pertencentes à classe dos trabalhadores. 
As determinações de acontecimentos históricos e processos sociais ocorridos no Chile do início do século XX são concebidas em Hijo de Ladrón por meio de uma técnica narrativa que consiste na combinação dos sucessos individuais do protagonista, que se desenvolvem em meio a lugares e conjunções apoiados na realidade histórica. Todavia, estas conjunções históricas não aparecem apequenadas como meros informes proporcionados por Rojas, de forma a reduzir o livro à descrição dos quadros de costumes. A impressão de realidade, na obra, mais do que chegar ao leitor através do simples documentário, apresenta-se como parte integrante da ação, de forma que o traço da sociedade chilena descrita mostra-se organicamente imiscuído no enredo. Deste modo, mesmo quando o autor diz que determinado fato "aconteceu" em sua vida, dada a estrutura da obra, este acontecimento não passa de uma representação da vivência empírica.

Antonio Candido, no conhecido artigo "Literatura e personagem", comenta a este respeito acerca da poesia, mas podemos estender suas observações à obra literária de ficção em geral:

(...) é perfeitamente possível que haja referência indireta a vivências reais; estas, porém, foram transfiguradas pela energia da imaginação e da linguagem poética que visam a uma expressão "mais verdadeira", mais definitiva e mais absoluta do que outros textos. O poema não é uma "foto" e nem sequer um "retrato artístico" de estados psíquicos; exprime uma visão estilizada, altamente simbólica, de certas experiências. Mesmo em versos altamente confessionais (...) não se deve confundir o Eu lírico dentro do poema com o Eu empírico fora dele. (CANDIDO, 2011, p. 22)

Exemplo marcante de um episódio representativo de fatos empíricos é cena do motim no meio do romance, quando Aniceto - recém chegado no Chile - se vê envolvido numa revolta popular em Valparaíso, motivada pelo aumento abusivo das passagens de bonde. Manuel Rojas conta, em sua Antología 
Autobiográfica, que este episódio do livro "ocurrió en Valparaíso en 1914 o principios de 1915". O mesmo que acontece com Aniceto Hevia aconteceu com ele próprio, e a diferença está no desfecho da situação, pois não adoeceu como o protagonista, e depois de doze dias preso, foi posto em liberdade (ROJAS, 2008, p.103).

A forma como o episódio é descrito também pode ser vista como uma mostra dos protestos que se tornaram frequentes no Chile a partir dessas primeiras décadas do século XX, tais como a tumultuada Semana Roja, ocorrida em 1905, quando manifestantes populares solicitaram das autoridades a derrogação do imposto de importação do gado argentino ${ }^{4}$. No livro de Rojas, a descrição dos bondes - ícones de empresas nacionais de exploração estrangeira - destruídos pelos insurgentes, soma-se ao relato das desordens públicas que atravessaram a noite mantendo o povo nas ruas. Às fortes palavras de ordem proferidas pelas massas ("-iMueran los verdugos del pueblo!" - HL, p. 84) soma-se a repressão das Forças Armadas, exibida pelos soldados montados a cavalo, a bradar pelo restabelecimento da ordem. Esses episódios, historicamente, são resultantes da indignação do povo, que em diversas situações, manifestou-se de modo violento. Tentaremos, em seguida, explicar mais a fundo as causas desta indignação.

Até a primeira metade do século XIX, os setores populares chilenos eram constituídos principalmente por habitantes rurais. A partir da segunda metade do século a mão de obra começou a se deslocar em direção aos grandes centros urbanos, forçando pela primeira vez a coexistência de pobres e ricos no mesmo espaço. Todavia - por exemplo, em Santiago -, era normal, por uma questão "estética", que a miséria fosse ocultada para que a cidade passasse uma imagem de adequadas condições de vida. Assim os pobres, desde o início, tiveram que se instalar nas áreas mais distantes do centro. Espinoza conta que no começo de 1870 o intendente Benjamín Vicuña estabeleceu critérios para estabelecer limites urbanos entre a área residencial da elite e a dos pobres: uma espécie de cordão sanitário que protegeria a "culta capital do Chile contra as influências pestilentas dos arrabaldes". Em 1872 foi criada uma comissão para estabelecer "bairros obreiros saudáveis", mas o que

\footnotetext{
${ }^{4}$ Sobre este episodio, ver em ESPINOZA, Para uma historia de los pobres de la ciudad .1988, p. 22
} 
aconteceu de fato foi a erradicação de conventillos ${ }^{5}$ das áreas que eram pertencentes à "cidade culta" (ESPINOZA, 1988, pp. 19-21).

$\mathrm{Na}$ cidade, o tipo de moradia popular mais comum eram os conventilllos, descritos por Galdames como velhos casarões alugados por quartos, os quais nasceram como resposta à densidade urbana crescente, e, num primeiro momento, obedeceram a uma construção regulamentada dentro do perímetro urbano. Todavia, pouco tempo depois essa regulamentação foi abandonada e nesses espaços, as famílias viviam sem as menores condições higiênicas (GALDAMES, 1999, p. 275). Este aspecto aparece em Hijo de Ladrón através dos comentários do narrador protagonista. Ele explica que nos conventillos existe uma grande diversidade de tipos, tais como ladrões, policiais, trabalhadores, mendigos, assaltantes e comerciantes. São pessoas que mudam de endereço com muito mais frequência que de roupa íntima, mas no final das contas, "existen y necesitan exactamente de todo lo que los demás necesitan" (HL, p.228). Em outro trecho, Aniceto Hevia comenta que muito pouca gente sabe a diferença entre um indivíduo criado num lar onde há limpeza, um pouco de ordem e certos princípios morais (ele diz se enquadrar nesta categoria) e outro, que não teve o que se pode chamar de lar, com a configuração de uma casa com quartos. Lugares "sin luz, sin aire, sin limpieza, sin orden, sin instrucción, sin principios de ninguna especie, morales o de cualquiera otra índole" ( $H L$, p.143).

O historiador Ricardo Donoso, a respeito desse mesmo tema, observa que "el problema del mejoramiento de la habitación popular gravitaba intensamente en campos y ciudades, donde en inmundas habitaciones, conocidas con el nombre de conventillos, vivían en deplorable promiscuidad las clases desvalidas" (DONOSO, 1963, p. 97). No livro de Rojas o narrador descreve, desde o seu ponto de vista, o modo como subsistem os moradores dessas miseráveis habitações:

(...)el padre llega casi todos los días borracho, grita, escandaliza, pega a la mujer, a los niños y a veces al tío, al yerno o al allegado; no siempre hay qué comer, mejor dicho, nunca se sabe cuándo habrá de comer y qué; el padre no

\footnotetext{
${ }^{5}$ Equivalentes a cortiços em português.
} 
trabaja o no quiere trabajar; el tío es inválido y el allegado come donde puede y si puede; el yerno bebe también o no trabaja o no quiere trabajar, es peón o comerciante de ínfima categoría: recoge papeles o huesos o excrementos de perros para las curtidurías o para quién sabe qué diablos; la mujer lava o mendiga; los niños comen lo que les dan cuando les pueden dar algo o lo que piden o les dan los vecinos, que no siempre pueden dar y que a veces, queriendo, tampoco pueden; a veces roban - el hambre les obliga - y miran y sienten sobre sí y alrededor de sí y durante años, durante infinitos años, aquella vida sórdida. No pueden pensar en otra cosa que en subsistir y el que no piensa más que en subsistir termina por encanallarse; lo primero es comer y para comer se recurre a todo; algunos se salvan, pero en una ciudad existen cientos y miles de estos grupos familiares (HL, p. 143).

Esta situação não significava que os setores populares fossem propensos ao tipo de vida descrito, mas este se dava porque eles se encontravam segregados de um sistema que não Ihes levava em consideração e nem os beneficiava com suas reformas políticas e sociais. A seguir, podemos observar, numa reflexão tecida pelo narrador, uma síntese do sentimento popular de ser ignorado do sistema de bem estar social, que pode ir aos poucos culminando numa revolta violenta:

La dueña de la casa, la mujer del obrero sin trabajo o con salario de hambre o enfermo, recurre a todo: vende los zapatos y la ropa, empeña el colchón, pide prestado, hasta que llega el momento, el trágico y vergonzoso momento en que la única y pequeña esperanza ¡vaya una esperanza! es el almacenero(...) El almacenero, con el pescuezo erguido y duro, mira hacia otra parte, mientras fuma su mal cigarrillo; siente, íntimamente, un poco de vergüenza, pero, ¿adónde iría a parar al siguiera fiando a todo el mundo? Él también debe vivir. La mujer, con su canastita rota y su pollera raída, sale, avergonzada también, con la vista baja y el obrero, que espera en la pieza del conventillo la vuelta de la mujer para comer algo, aunque sea su pedazo de pan, siente que el odio le crece hasta el deseo del crimen ( $H L$, pp. 91-92).

Todo o pano de fundo histórico observado deixa patente, na obra de Rojas, o universo de convivência do personagem Aniceto Hevia, inclusive entre os habitantes desses conventillos. Em nenhum dos espaços pelos quais ele 
transita se relaciona com indivíduos de esferas sociais mais elevadas e nem sequer existe qualquer descrição de ambientes ricos em seu caminho.

A explicação sobre o sentimento de revolta do povo:

La aventura no terminó allí: el motín bullía por toda la parte baja de la ciudad, excepto en el centro, donde estaban los bancos, los diarios, las grandes casas comerciales; en algunas partes la multitud apedreó los almacenes de comestibles, de preferencia los de la parte amplia de la ciudad y los que estaban al pie de los cerros. No tenían nada que ver, es cierto, con el alza de las tarifas de tranvías, pero muchos hombres aprovecharon la oportunidad para demostrar su antipatía hacia los que durante meses y años explotan su pobreza y viven de ella, robándolos en el peso, en los precios y en la calidad, la mezquindad de algunos, el cinismo de otros, la avaricia de muchos y la indiferencia de todos o de casi todos (...) (HL, p. 90)

As fronteiras estabelecidas entre o mundo rico e o pobre se destacam no episódio em que Aniceto se encontra na prisão depois do motim e chega à cela um homem de barba feita, arrumado - ostentando terno, gravata, colete, meias de seda e chapéu panamá -, com um relógio de ouro. Pelos seus gestos de inquietação e pela forma de sentar-se à beira da tarimba próxima à grade, é visível que o homem sente que não pertence àquele mundo, como se estivesse certo de que alguém de seu círculo rapidamente deve aparecer para resgatá-lo daquele improvável lugar em que se encontra. Quando os "companheiros de cela" roubam-lhe o relógio, o indivíduo, perplexo, chama a polícia. Ao ser indagado pelo guarda sobre o porquê de levar um relógio de ouro para a cadeia, sua interessante e ingênua resposta denota a alienação social, símbolo de toda uma classe que desconhece o lado marginal da sociedade:

El gendarme hizo una inspiración profunda:

- ¿Y usted estaba en este calabozo con un reloj de oro en el bolsillo?

El hombre manoteó al responder:

- Claro, en el bolsillo; era mío. (HL, p. 151) 
O poeta é um fingidor.

Finge tão completamente Que chega a fingir que é dor A dor que deveras sente.

E os que leem o que escreve, Na dor lida sentem bem, Não as duas que ele teve, Mas só a que eles não têm.

E assim nas calhas de roda Gira, a entreter a razão, Esse comboio de corda Que se chama coração.

Fernando Pessoa 


\section{ROMANCE DE TRAÇOS AUTOBIOGRÁFICOS}

Manuel Rojas nasceu em Buenos Aires, em 1896. Em 1899, seus pais chilenos foram viver em Santiago. Em 1903, com a morte do pai, sua mãe retornou à Argentina, onde o menino teve que se acostumar a uma vida difícil e por este motivo teve poucos estudos formais até os onze anos, quando teve que começar a trabalhar. A família morava do lado de um conhecido ladrão, figura que mais tarde inspiraria este, seu mais célebre romance. Aos dezesseis anos, Rojas retornou ao Chile com dois companheiros anarquistas, cruzando a pé a Cordilheira dos Andes, até chegar em Santiago. Neste meio tempo, desempenhou os mais diversos ofícios para sobreviver: foi pintor e aplicador de massa em portas e janelas, vendedor de jornais, eletricista, atividades essas que Ihe propiciaram o contato com vários tipos humanos tais como operários, mineiros, indigentes ociosos e bandidos.

À época existiam no Chile, bem como em outros países da América Latina, diversos setores ligados à esquerda que lutavam por melhores condições de vida para as massas: os anarquistas. Jovem e receptivo para as novas ideias, Rojas viu-se fortemente influenciado pela ideologia anarquista. Durante um certo tempo, desde sua chegada ao país, teve uma vida um tanto nômade, até que a mãe mudou-se também para o Chile e consertou em parte sua instabilidade. No trecho a seguir o autor fala um pouco do seu modo de vida, quando de sua chegada:

Durante varios meses vagué de un conventillo a otro, leyendo, trabajando a veces y hablando sin cesar de anarquismo, de literatura, de ladrones, de mujeres, de aventuras, de viajes. Algunos de los jóvenes anarquistas que conocí decidieron convertirse en pistoleros o apaches, al estilo de Bormott y de Garnier - anarquistas franceses que se dedicaron a asaltar bancos para ayudar a la propaganda de esas ideas -, y sin querer, peor aun, temiéndolo, me vi metido en vastos proyectos de robos de automóviles (...) El azar, la necesidad de ganarme la vida en forma inmediata y el deseo de vagar me libraron de 
tomar parte en la realización de algunos de esos proyectos (ROJAS, 1962, p. 20).

Todos estes dados relativos às experiências do autor encontram-se no interessante livro Antología Autobiográfica (1962), citado acima, no qual Rojas conta como, de diversas maneiras, suas experiências pessoais ingressaram em seus escritos. $O$ autor admite que, mesmo quando seus personagens não são diretamente espelhados em pessoas reais, trata-se de "composiciones 0 desfiguraciones" (ibidem, p. 104).

Mas para entender de modo mais abrangente sua concepção de literatura, é bom dar uma olhada no seu livro De la poesía a la revolución, publicado em 1938, mais especificamente no capítulo intitulado "La novela, el autor, el personaje y el lector". Neste capítulo, Rojas desenvolve, sob a forma de ensaio, reflexões a respeito dos conceitos literários no romance e as formas de transformação dos mesmos ao longo do tempo. Verdade é que essa análise periódica da literatura já se encontra muito mapeada atualmente pela teoria literária. Todavia, em 1938 a crítica literária era ainda um campo recente e pouco divulgado na América Hispânica. Erich Auerbach, em sua Introdução aos Estudos Literários, de 1943, comenta que na Europa as formas de estudos literários conhecidos e praticados antes do século XIX eram a bibliografia, a biografia e a crítica estética. Portanto, ao observamos a tentativa de problematização de Rojas, no sentido de teorizar acerca da história da literatura latino-americana, percebemos a demonstração de um esforço lúcido por parte do autor, que reflexiona sobre o romance e suas características. É interessante notar que Rojas, em sua visão de escritor, dirige sua análise mais ao personagem do que ao processo narrativo propriamente dito. $O$ romance, na visão de Rojas, tem amplitude quase ilimitada porque aceita tudo: descrições de indivíduos, famílias ou épocas inteiras, sem chegar com isso a esgotar o seu material, pois "todo ha sido y es material útil para el creador literario, para el novelista" (ROJAS, 1938, p. 88). Para Rojas, o romance tem dois eixos permanentemente sujeitos a mudanças: a realização artística composta por técnica, estilo e definição, e a realização psicológica que corresponde à exposição, exame ou descrição dos personagens e da vida, interna ou externa, 
dos mesmos. Ele se detém com mais interesse na realização psicológica do que sobre a artística, embora reconheça que em ambas os valores não estão nitidamente separados, por se complementarem profundamente. Este exame mais minucioso tem a ver com o aspecto formal, posto que a narração depende do ser humano, ou pelo menos, de condições humanas, sendo impossível fazer um romance de pura poesia, de paisagens ou pensamentos.

A este respeito, também o crítico brasileiro Anatol Rosenfeld comenta que "a narração - mesmo a não fictícia - , para não se tornar em mera descrição ou em relato, exige, portanto, que não haja ausências demasiado prolongadas do elemento humano (este, naturalmente, pode ser substituído por outros seres, quando antropomorfizados) porque o homem é o único ente que não se situa somente no tempo, mas que "é" essencialmente tempo." Ele explica que isto ocorre porque o homem, afinal, só pelo homem se interessa e só com ele pode identificar-se realmente (ROSENFELD, 2011, p. 28).

O autor compara o desenvolvimento do romance ao longo do tempo com a evolução das ciências naturais - como a anatomia, a fisiologia e a psicologia -, que caminharam do estudo de objetos simples aos mais complexos. Explica que "cada época literaria, cada generación de escritores, en todas partes, conquista una nueva capa, un nuevo tejido y va descendiendo despacio hacia el oscuro vivir físico y mental del ser humano" (Ibidem, p. 91). Neste sentido, o gênero romance já teria cumprido dois períodos e no momento (lembremos que este enunciado data do ano de 1938), cumpria o terceiro. Por sua vez, para Rojas estes períodos se compõem, respectivamente, de uma 'fase afetiva' também denominada "infância da criação romanesca", uma 'afetiva intelectual' situada na metade do caminho, entre a juventude e a maturidade, e a terceira, composta pelos elementos das fases anteriores, mais a sensibilidade. Quando Rojas fala, a partir de "Ensayo de la mañana" (1940), sobre sua 'nova maneira de escrever', deixa claro que observa que, deste momento em diante, considera-se participante do terceiro período. É por isso que seus escritos, ao assumirem a interioridade dos personagens, revelam traços e episódios ligados à sua biografia, posto que, como já foi mencionado, para ele é impossível que o romancista possa narrar a interioridade de um outro. 
Os personagens da chamada 'fase afetiva' apenas atuam e falam e suas ações, reações e estados de ânimo são simples, pois vencem ou morrem, estão alegres ou tristes. Neles inexiste o silêncio, posto que não possuem vida interior: são heróis 'velozes na corrida e infatigáveis na luta', que se movem em grandes áreas geográficas. Neste momento da criação literária os seres divinos influenciam diretamente nas aventuras vivenciadas pelos personagens, como se pode observar na llíada. O narrador "miraba desde afuera y creaba desde afuera, dando a los personajes sólo lo necesario para existir. A este respecto es curioso observar cómo, a medida que las ciencias que estudian al hombre avanzan en el conocimiento de este, los novelistas, por su parte, penetran más el personaje" (Ibidem, p. 95).

Os personagens do segundo momento também atuam e falam, mas sua atuação é mais lenta e reduzida, mesclando-se a certos momentos de silêncio, nos quais a meditação aparece como elemento novo. Compõe este painel uma gama de tipos semi sedentários, semi sensíveis, bons ou maus, sem grandes desvios psíquicos nem complexidades profundas, tais como se caracterizam diversos personagens de escritores como Daudet, Dickens e Stendhal. $\mathrm{Na}$ verdade, Rojas tenta sistematizar os processos narrativos que hoje são amplamente discutidos pela crítica literária.

Sabemos que Edward Morgan Forster, em Aspectos do Romance, caracteriza os personagens sem complexidade psíquica como planos, e explica que "as personagens planas são construídas em torno de uma única ideia de qualidade: quando nelas existe mais de um fator, atinge-se o início da curva que leva à personagem redonda" (FOSTER, 1937, p.93). Neste segundo caso já se encontram diversos personagens dos autores acima mencionados por Rojas.

Como exemplo das mudanças que se operam entre os períodos literários citados, Rojas menciona que, enquanto na llíada todo um povo luta contra outro povo, em $O$ Vermelho e o Negro, Julián Sorel parece lutar sozinho e contra si mesmo. E explica que "a medida que la vida heroica se desvanece, a medida que los dioses son negados $u$ olvidados, a medida que la tierra se puebla y que la civilización industrial progresa, la acción del personaje disminuye en proporción. Las condiciones económicas también influyen en él. 
Debe alimentarse, y como no es dios ni héroe, debe trabajar, y el trabajo no le permite, salvo excepciones, muy largas ociosidades" (Ibidem, p. 97).

É possível deduzir que este momento descrito por Rojas corresponde ao chamado período realista da literatura ocidental que teve seu apogeu em meados do século XIX na Europa e se consolidou com as ideias de uma arte objetiva e social, construída a partir de critérios racionais cientificistas, na busca de leis que explicassem a realidade, por meio das teorias positivistas, evolucionistas e darwinistas. A organização narrativa, norteada por essas concepções, é elaborada à maneira de experimento laboratorial e por isso 0 comportamento dos personagens é previsível e explicável "cientificamente". Outro brasileiro, o austríaco naturalizado Otto Maria Carpeaux, em seu artigo "O reino dos Karamázov", comenta a pretensão destes romancistas de informar-nos sobre nossa realidade, com o seu traço característico de dizer sempre a "verdade". Porém, nos escritores deste período realista há um desencantamento no tocante à exatidão das leis científicas. Deste modo, aspectos tipicamente românticos ligados à subjetividade e à imaginação, são resgatados. Neste sentido é que se passa a explorar na narrativa o caráter interior dos personagens, por meio do tempo psicológico (CARPEAUX, 1942, p.9).

Antonio Candido explica que os romancistas do século XVIII se deram conta de que a noção de realidade é reforçada pela descrição dos detalhes e que os realistas do século XIX (tanto românticos como naturalistas) levaram ao máximo esse povoamento do espaço literário pelo pormenor, que era uma técnica para convencer pelo exterior, pela aproximação com o aspecto da realidade observada (CANDIDO, 2011, p. 79).

Paulo Rónai e Aurélio Buarque de Hollanda, no prefácio de um dos volumes da coletânea de contos Mar de histórias, lembram que "quando se pretende dar uma visão sincrônica de um gênero literário pelo mundo afora, chega-se à conclusão de que é impossível estabelecer divisões estanques entre as escolas sucessivas". Deste modo, o Realismo surgiu com nomes tais como Balzac, Merimée e Turgueniev e depois, se foi confirmando em obras de Daudet, Maupassant e Jacobsen, entre outros, mas, à margem, o Romantismo continuava a sobreviver" (FERREIRA \& RÓNAI, 1999, p.7). 
Na verdade, como já dissemos, com sua visão de escritor, Rojas põe em evidência mais os personagens do que a construção e a figura do narrador, que é o grande elemento que permite verificar melhor essa evolução da narrativa ocidental através dos tempos. Segundo ele, é nessa progressão que o personagem avança e alcança um nível de "maturidade psíquica". Compara então a diferença na vivência das ações entre o personagem das criações literárias mais antigas com os da terceira fase. Toma como exemplo o romance de Marcel Proust, onde durante vinte páginas o personagem não realiza ação exterior alguma, apenas sonha ou pensa diante de uma xícara de chá. O romancista da terceira fase literária abandonou o "caminho solar", próprio da epopeia, e encontrou outro, silencioso, chegando à conclusão de que o mais importante é a vida psíquica de seus protagonistas. Neste sentido, o escritor observa que "en ese soñar, en ese pensar, en ese divagar, la vida mental, la vida vegetativa, la vida fisiológica, la vida consciente, subconsciente o inconsciente, la vida de las percepciones, de las sensaciones y de las representaciones, la vida de la tercera fase, en fin, aparece y muestra matices maravillosos, que no tuvieron nunca los dioses y los héroes" (ROJAS, 1938, p. 98).

Antonio Candido comenta que nomes como Baudelaire, Nerval e Dostoievski prepararam caminho para escritores como Proust, Joyce, Kafka, Pirandello e Gide. Isto porque, quando se teve noção mais clara do mistério dos seres, renunciou-se, em psicologia literária, a uma geografia precisa dos caracteres. A marcha do romance moderno (do século XVIII ao começo do XX) foi no rumo de uma complicação crescente da psicologia dos personagens. Deste modo, o senso de complexidade do personagem, ligado ao da simplificação dos incidentes da narrativa e à unidade relativa de ação, marca o romance moderno, cujo ápice, a este respeito, foi o Ulysses de James Joyce (CANDIDO, 2011, pp. 60-61).

A respeito desta complicação da psicologia dos personagens, Forster explica que enquanto a personagem plana é facilmente reconhecida e lembrada, a personagem esférica reflete ambiguidade, possuindo uma caracterização relativamente elaborada e não definida, devido à sua condição de imprevisibilidade: 
[...] a personagem redonda convoca não raro procedimentos específicos. Projetando-se no tempo, os conflitos e mudanças vividos por uma personagem redonda traduzem-se numa temporalidade psicológica, eventualmente modelada através do monólogo interior; trata-se, afinal, de uma específica modalidade de focalização interna, solução técnico-narrativa que muitas vezes manifesta a presença de uma personagem redonda, ajustando-se, pelas suas potencialidades de representação psicológica, às exigências próprias de uma personagem desta natureza (FORSTER, E. M., 1937, pp.93-106).

Acompanhando a reflexão de Rojas, para o personagem da primeira fase, o problema era o ambiente em que se movia. $O$ da segunda chegou às raízes íntimas do seu ser psíquico. Já para o personagem da terceira fase, o problema é de índole interior, a própria subjetividade do homem, em toda sua complexidade. É esta categoria cada vez mais sutil do problema, o que leva a narrativa a realizar dentro do protagonista profundas excursões e verdadeiras aventuras psíquicas, durante as quais o homem descobre e mostra estranhos mundos regidos por forças ainda mais estranhas, que existiam antes e existem a cada dia mais nele, mas das quais não tinha, até pouco tempo, senão como reflexos sem origem aparente e direção determinada. Como resultado destas conjunções, o personagem da "maturidade" passou a ser cada vez mais imóvel, posto que as problemáticas não necessitam ser buscadas no mundo externo.

A este respeito, Antonio Candido observa que o aprofundamento da investigação psíquica na literatura beneficiou-se com o desenvolvimento dos estudos da psicologia moderna. Comenta que foi quando se teve noção mais clara do mistério e da imprevisibilidade dos seres humanos que "renunciou-se, em psicologia literária, a uma geografia precisa dos caracteres". Por isso, o romance moderno foi deixando de lado a complexidade dos incidentes na narrativa, em favor da complexidade crescente da psicologia dos personagens. Como a personagem deve lembrar que é um ser vivo, mantendo relações com a realidade do mundo, para que se possa equiparar ao nosso conhecimento na vida, Candido explica que "houve na evolução técnica do romance um esforço para compor seres íntegros e coerentes, por meio de fragmentos de percepção 
e de conhecimento que servem de base à nossa interpretação das pessoas" (CANDIDO, 2011, pp. 56-65).

Ainda segundo Rojas, para descrever este terceiro protagonista, para observá-lo, o romancista possui apenas o próprio modelo, descrevendo-se a si mesmo. Um criador literário pode encontrar um indivíduo real e estudar sua vida, averiguando o que fez ou disse, mas não pode, todavia, saber o que ocorreu nas profundezas de sua consciência. A vida interior do próprio escritor é que dá os dados necessários. Mas a vida psíquica de um indivíduo não se encerra em si mesma, pois sempre está conectada com outros indivíduos, com os quais está em conformidade ou em oposição. Para Rojas o escritor "contiene en si un mundo de posibilidades humanas de toda índole". E não somente ele: todos nós, escritores ou não, contemos este universo, mas somente aos escritores é dado expressá-lo porque "su hipersensibilidad, fronteriza en la mayoría de los casos a un estado psicopático, le permite auscultar, sentir y hacer vibrar todo ese mundo heredado, que bulle en silencio, amenazante o sereno, y que sólo está retenido en él por un agudo control consciente y por su misma condición de escritor, es decir, porque puede expresarlo." (ROJAS, 1938, pp. 102-103)

Como podemos observar, já em 1938, Manuel Rojas possuía uma acentuada consciência a respeito do que ele chamava o "personagem da terceira fase da criação literária”, mas sua obra irá se constituir de modo pleno com os elementos mencionados acima apenas em 1951, com a publicação de Hijo de Ladrón. A despeito de sua consciência, lembremos que a tendência de Rojas, como escritor, é lançar um enfoque maximizado sobre a figura do personagem. Por isso, voltando a Candido, a verdade da personagem não depende apenas de suas relações com a vida, de modelos observados interna ou externamente ao autor:

Conclui-se, no plano crítico, que o aspecto mais importante para o estudo do romance é o que resulta da análise da sua composição, não da sua comparação com 0 mundo (CANDIDO, 2011, pp. 74-75). 
Verdade é que em Manuel Rojas toda a obra é, em certa medida, autobiográfica, posto que apresenta ecos de suas andanças, de seus múltiplos trabalhos desenvolvidos, dos tipos humanos que conheceu e da ideologia política que carregou desde a adolescência. Porém em Hijo de Ladrón, além da apresentação desses fatores conhecidos, Rojas efetivamente adentrou o universo psíquico com o personagem Aniceto Hevia, e como já havia mencionado não ser possível narrar a interioridade de outro - de modo profundo -, observamos que Aniceto Hevia apresenta-se como seu alter-ego.

Como mencionamos antes, o menino Manuel Rojas morou com sua mãe em Buenos Aires, vizinho de um ladrão noturno espanhol, chamado Aniceto Hevia, conhecido como El Gallego, que vivia com sua mulher, uma chilena chamada Carolina e quatro filhos. Certo dia, a polícia apareceu e levou toda a família de Hevia, exceto o pai, que não estava em casa. Foi quando o menino Rojas descobriu que o vizinho era ladrão, mas não deu importância ao fato no momento, pois segundo suas palavras, as pessoas do "bajo pueblo" não se importavam com o que faziam aqueles pelos quais sentiam apreço ou admiração. Em outra oportunidade, El Gallego foi levado preso e desapareceu por meses. Neste meio tempo, escreveu cartas e por fim voltou com umas "hermosas barbas"6. Na mente infantil de Rojas, todos estes fatos teriam concorrido para produzir uma admiração que permaneceu depois em suas lembranças e em sua produção literária (ROJAS, 2008, p. 100).

Em Hijo de Ladrón também verificamos esta condescendência em relação à transgressão da lei, por exemplo, no capítulo primeiro da quarta parte do romance. Aniceto Hevia, o narrador em primeira pessoa, conta que durante um tempo de sua infância ele e sua família viveram em Rosario, em uma casa que o pai alugara de uma senhora viúva que morava em uma casinha no fundo do mesmo quintal. A princípio, não agradava ao pai a ideia de viverem tão próximos de uma desconhecida. Porém a idosa foi se mostrando tão discreta que foi passando a ser uma pessoa querida. Vale destacar uma cena sobre essa fase da infância do narrador-protagonista: No jardim da vizinha havia

\footnotetext{
${ }^{6}$ No romance, o paralelo é impressionante: (...) mi padre desaparecía por cortas o largas temporadas; viajaba, se escondía o yacía en algún calabozo; reaparecía, a veces con unas hermosas barbas, siempre industrioso, trabajando sus moldes de cera, sus llaves, sus cerraduras. (HL, p. 11)
} 
árvores frutíferas e um dia de verão, quando o pessegueiro estava carregado e o menino cobiçava seus frutos, a velhinha encontrava-se no jardim, tentando ler um jornal. Ao vê-lo, ela confessou que lia com dificuldade e pediu-lhe para ler para ela, em troca de alguns pêssegos. No começo da cena, a leitura diária de Aniceto tem como alvo a retribuição dos frutos, mas depois ele vai tomando gosto pelas leituras que, ao mesmo tempo em que aumentam seu universo cultural, o fazem ir mal na escola (podemos observar que este incidente prenuncia que a formação do protagonista não se encontra necessariamente ligada às esferas regulares da sociedade ). Uns dias depois dessa cena, no jornal que a senhora costumava ler, aparece uma fotografia do pai de Aniceto, com seu nome, seu apelido, "Gallego", seus antecedentes criminais e uma advertência de que se trata de um ladrão perigoso. Ela não tece nenhum comentário a respeito, embora 'el gallego', mesmo assim, venha lhe comunicar que deixará a casa. A velhinha pergunta então:

- ¿Es por lo del diario?

Mi padre no contestó, y la señora dijo:

-Sí es por lo del diario, don Aniceto, no se vaya usted. No me importa nada lo que diga el diario y no tengo ninguna queja contra usted. Cada uno se gana la vida como Dios le deja y usted es un hombre decente. Quédese. (HL, p. 250)

A fala da personagem apresenta correspondência direta com o sentimento que Rojas teve em sua infância. É interessante observar como neste diálogo é nítida uma idealização sobre a mentalidade do povo a respeito dos conceitos de religião, pecado e moralidade. Situado ideologicamente dentro do contexto histórico da esquerda latino-americana no começo do século $X X-$, o autor apresenta seus personagens marginais como seres quase sempre capazes da partilha. Em sua visão relativizada, exibe todo um quadro de seres que se ajudam, tornando menos dolorosa a existência. São vários os exemplos, entre os quais encontramos o episódio do vagabundo que dá um par de sandálias a um garoto com os pés feridos. O inverossímil da narrativa, que exibe o olhar parcial de Rojas, se encontra no fato de que ao entrar em contato com as duras realidades do grande mundo, os maus tratos pelos quais passa o protagonista não provêm dos indivíduos "rotos" e sim, quase exclusivamente, das forças reguladoras da lei. A seguir observamos o momento em que o jovem sai da 
prisão, fraco e doente, após ter sido acusado de um crime que afirma não ter cometido:

Creo que, primero o después, estuve preso. Nada importante, por supuesto: asalto a una joyería, a una joyería cuya existencia y situación ignoraba e ignoro aún (...) Al ser dado de alta y puesto en libertad, salvado de la muerte y de la justicia, la ropa, arrugada y manchada de pintura, colgaba de mí como de un clavo. ¿Qué hacer? (HL, p. 3)

Porém, no início de suas andanças, ao se deparar com o manco Isaías, o jovem é maltratado pelo mesmo Isaías: isto the serve como preparo para as privações que enfrentará ao encarar sozinho a vida: nem todos em redor são confiáveis

Isaías era algo así como una mula y como una mula procedía con toda persona o animal que estuviese bajo su dependencia: pateaba con su pierna de palo argollada de hierro, al perro, a las gallinas, a las gallinetas, a los pavos y a Bartola, la de los hermosos ojos; nada se le escapaba (...) Pero mi coraje no fue pasivo: busqué, mientras lloraba, un trozo de ladrillo, y lo dejé en un sitio que me quedara a mano en cualquier momento encima de uno de los horcones del gallinero. Días después, dos o tres, recibí la segunda patada, la última (...) Reteniendo los sollozos lo tomé y casi sin apuntar, lo disparé, dándole en el cráneo (HL, p. 67).

Isaías é um exemplo de homem contra o qual o narrador expressa claro desprezo. Há um outro tipo pelo qual ele sente temor. O que há de comum em ambos, segundo seu olhar, é que nenhum deles possui uma base verdadeiramente humana em que apoiar-se, e em nome do dinheiro são capazes das violências mais brutais. Daí que esta classe de indivíduos se apresente sempre descrita a partir de comparações animalescas, como vimos em relação a Isaías e como se observa a seguir, no episódio em que os ladrões se aproveitam do motim dos bondes para fazer arrastões em meio aos tumultos. O grupo de jovens presos gera no protagonista a sensação de um excesso de violência, proporcional à falta de princípios morais: 
Pegar, herir, romper, es para ellos un hábito adquirido que les llega a parecer natural; hábito que, cosa terrible, significa un modo de ganarse la vida, de poder comer, beber, vestirse. No podía reprocharles nada, pues no tenían la culpa de ser lo que eran o cómo eran, pero les temía, como un animal criado en domesticidad teme a otro que ha sido criado en estado salvaje ( $H L$, pp. 143, 144).

Em vista de todas estas correlações entre literatura e autobiografia, por mais que Rojas insista que seus escritos são cópias, composições ou desfigurações de suas vivências, podemos dizer com Anatol Rosenfeld, que "na ficção narrativa desaparece o enunciador real. Constitui-se um narrador fictício que passa a fazer parte do mundo narrado, identificando-se por vezes (ou sempre) com uma ou outra das personagens ou tornando-se onisciente etc." (ROSENFELD, 2011, p. 26). Além do mais, lembremos com Antonio Candido, que o fator mais importante para a análise do romance é o resultante da análise de sua composição, e não da sua comparação com o mundo. 


\subsection{BANDITISMO: UM CONCEITO RELATIVO}

Sobre a temática do banditismo, há um interessante texto escrito pelo poeta Enrique Lihn, em que ele parte de uma das acepções da palavra bandido, no dicionário, e questiona a validade da fria e abstrata definição atemporal ("denota a un fugitivo de la justicia llamado por bando, situación en la que sólo podría encontrarse uma persona 'perversa y desenfrenada'). Lihn argumenta que a linguagem viva se alimenta da história e desemboca na literatura. Deste modo, a ideia que se possa ter da justiça e de seus transgressores - em distintos contextos literários - torna-se algo decisivo para captar, "en la forma más directa posible, todo el sistema de creencias en que se funda una narración por alejada que parezca del juego de las ideas y/o de las ideologías conscientes". (LIHN, 1972, p. 6) É por isso que é possível, em dado momento histórico, que um autor possa representar a mentalidade de uma classe de diferentes modos, sem a necessidade de emitir nenhum juízo.

A partir do final do século XIX, continua Lihn, os folhetins - que muitas vezes traziam histórias de bandidos - caíram nas graças do grande público chileno. Diz Lihn: "es entretenido y gracioso. Un extemporáneo llamamiento al orden que parecería proceder de la sociedad dieciochesca chilena. Ésta fue al mismo tiempo implacable y condescendiente con el bandidaje. En cualquier caso, muy permeable al espíritu aventurero" (Ibidem, p. 8). Sobre este tipo de leitura folhetinesca que apresenta uma sociedade permeável ao espírito aventureiro, talvez possamos definir o que acontece no episódio mencionado da viúva e do pai de Aniceto como uma mise en abyme: a senhora, ao mesmo tempo em que é uma leitora de folhetins de fins do XIX, é personagem de um romance que tem no centro de sua temática o universo marginal. Tudo isto na visão de um autor das primeiras décadas do século XX, extremamente sensível às injustiças sociais e que acreditava na força da literatura como poderoso instrumento de denúncia e de reformas. 
Manuel Rojas, assim como seu predecessor chileno, Baldomero Lillo (18671923), e de quem acolhe influências, tematiza os conflitos entre exploradores e explorados. Fernando Alegría, em um interessante artigo sobre Lillo, comenta aspectos de sua vida e obra, por meio dos quais é possível estabelecer claros paralelos com Manuel Rojas. Lillo trabalhou como empregado em uma mercearia e ali teve contato com mineiros que viviam em condições sociais lastimáveis. Samuel Lillo comenta que aquele trabalho na mercearia, onde o irmão começou a sentir o drama dos mineiros em Lota, teria sido preponderante para decidir sua vocação como escritor (ALEGRÍA, 1959).

Embora Baldomero Lillo nunca tenha se filiado a partido algum, suas vivências pessoais o direcionaram a nutrir simpatia pela esquerda política, mas sempre em um plano idealista, inspirado por um zelo humanitário. Neste sentido, "denunció al país un aspecto de la miseria económica y la corrupción moral reinantes, que hasta hoy se acostumbra identificar su obra literaria con la saga de los mineros del carbón. Desde este punto de vista, es decir, considerando a Baldomero Lillo como un escritor realista y popular, el fondo histórico de su obra está constituido por el proceso revolucionario que viviera Chile entre 1890 y 1920" (ALEGRÍA, 1959, p. 249) Além do mais, causou-lhe profunda impressão o romance Germinal, de Zola, obra em que se pode notar, como temática, a defesa ardorosa dos direitos das classes exploradas: foi justamente esta temática de conflitos sociais que 0 diferenciou substancialmente de seus colegas de geração. No entanto - prossegue Alegría -, ele nunca caiu no discursismo propagandista e sua mensagem encontrou eco na obra de escritores posteriores, entre os quais Manuel Rojas foi discípulo de suas ideias.

Dentro deste contexto é possível observar a simpatia - de nenhum modo panfletária - de Manuel Rojas contra a injustiça oficial. Ao assimilar as ideias anarquistas de seu tempo no que diz respeito à exaltação do homem livre, ele compreende o funcionamento social como um sistema que exclui as classes dominadas e por vezes as priva de prosperar honestamente. Rojas toma o partido dos seres marginais, entre os quais não exclui os bandidos e os ladrões (Ibidem, pp. 18-26). 
É necessário deixar claro, porém, que Rojas não faz apologia ao banditismo. Grínor Rojo introduz observações que corroboram o que mencionamos quando, no artigo "La contraBILDUNGSROMAN de Manuel Rojas" (ROJO, 2009, pp. 5-6), ele comenta que o juízo de Rojas em relação ao mundo dos delinquentes não é uniforme e que por isso não é possível falar em adesão incondicional ao grupo. É assim que ele distingue entre o meliante acanalhado e o ladrão profissional, "al que no es infrecuente que se lo describa como un 'trabajador' más." Mais adiante, acrescenta que em Hijo de Ladrón, bem diferente é o tratamento dado a personagens alcunhados de "hombres alcantarilla", "hombres rata" ou "hombres cuchillo", durante o motim de Valparaíso, ou quando o narrador se refere aos jovens com aspecto perigoso com os quais Aniceto compartilha a cela depois do motim" (ROJO, 2009, p.6). A seguir observamos um fragmento do romance que demonstra a caracterização depreciativa dos indivíduos que aparecem descritos de modo bestial, durante o motim:

Se formaron grupos constituidos por individuos que aparecían salidos de las alcantarillas - algunos se habrían podido tomar por enormes ratas -; barbudos, astrosos y de ojos brillantes, llenos de vida, inquietos, que no gritaban ni rompían faroles y que al parecer no sentían odio ni amor por nadie, pero que se apoderaban, con una asombrosa rapidez, casi animal, de cuanto se hallaba al alcance de sus manos; (...) - Nunca lo han trabajado a nadie y roban a todo el que pueden, a los pobres, en los conventillos, y a los borrachos, a las viejas, a los chiquillos; ni siquiera son ladrones; no son más que inmundos rateros. (HL, pp. 93, 95)

Dentro do grande conjunto marginal, Aniceto Hevia / El Gallego pertence ao subgrupo dos 'homens decentes', como menciona a idosa, ao pedir-lhe, sem sucesso, que ele não vá embora. Tendo em vista a visão relativa do povo, em relação à delinquência, segundo a ideologia de defesa dos explorados por parte de Rojas, torna-se coerente que Aniceto Hevia seja visto como 'homem decente': ele é apresentado pelo filho/narrador (de visão parcial, posto ser participante da trama) como um pai de família que cuida da esposa e dos filhos, calmo, e que além de não fazer mal às pessoas pobres, em alguns 
momentos pratica atos generosos. Em sua casa, ele cuida de um ladrão doente ou envia pequenos produtos furtados para o manco Isaías para que os venda e deles sobreviva. Sob esta ótica parcial, esse bandido a la "Robin Hood", mesmo quando pratica crimes, além de não usar a violência, é um especialista no roubo de joias, objetos supérfluos de uso restrito das classes abastadas.

Nas suas memórias, Manuel Rojas comenta que ao pensar em escrever Hijo de Ladrón, a família do ladrão Aniceto serviu-Ihe como ponto de partida e como base. Foi assim que ele próprio se transformou, no romance, em Luis Hevia, que teria o mesmo nome do pai, e que teria uma infância meio imaginária e meio real. Parte de sua adolescência seria imaginária, até o momento em que Manuel Rojas tomaria seu lugar e seu nome. Luis Hevia termina seu papel no momento em que retorna da colheita, e não encontrando ninguém decide abandonar Buenos Aires: daí em diante, em situações reais ou imaginárias, passa a assumir Manuel Rojas. Além de Luis Hevia/Manuel Rojas há outros personagens tirados do contexto histórico na primeira parte. São eles Aniceto Hevia e o vagabundo que Aniceto encontra às margens do rio Aconcágua. Nas partes terceira e quarta não há personagens que correspondam a seres reais: todos são fictícios, composições ou desfigurações. 
Existem diversos paralelos da obra de Manuel Rojas com a de Marcel Proust. Primeiramente, porque sabemos do fascínio à primeira vista pelo autor francês através do livro De la poesía a la revolución, publicado em 1938, no qual Rojas comenta que o primeiro contato com Proust Ihe descortinou um mundo desconhecido:

Leímos cuatro o cinco páginas y lo dejamos. Imposible, casi en todos los casos, poder leer más. No obstante esto, no nos daba la sensación de ser un mal escritor. Aquello no nos parecía ni bueno ni malo; simplemente, era raro, desacostumbrado, y no podíamos seguir leyendo. Días después o un mes más tarde, cogimos de nuevo el libro y lo leímos de un tirón. ¿Por qué nos sucedió esto? Porque en nuestra memoria no existía nada semejante; pero al cabo de esos días o de ese mes, la conciencia había ya absorbido esa nueva manera, tenía entrenamiento y podía asimilar, y asimilaba de prisa, deseosa de satisfacerse. El molde estaba hecho y se llenaba rápidamente. Era un mundo mental desconocido el que se nos ofrecía y entramos a él con un placer que no se nos olvidará tan pronto y al que volvemos cada cierto tiempo, pues aun no lo hemos absorbido lo suficiente (ROJAS, 1938, p. 114).

A partir desse fascínio é mais fácil estabelecer paralelos até mesmo entre o título da grande obra de Proust, Em busca do tempo perdido, e o nome inicial escolhido por Rojas para a publicação de Hijo de Ladrón: Tiempo Irremediable. Dado existir uma diferença abismal entre a realidade sócio-cultural da França e a do Chile, o autor chileno foi obrigado a que, para que o livro fosse publicado, o título fosse menos abstrato. Foi assim que um editor chamado Enrique Espinoza propôs o mais convencional Hijo de Ladrón.

Outro momento da obra de Rojas em que ficam patentes os paralelos com os moldes proustianos é a escrita do texto "Ensayo de la 
mañana"(publicado na Revista Babel, em 1940), feito com o propósito de integrar a parte inicial de Tiempo Irremediable / Hijo de Ladrón.

Esse ensaio trata do momento em que o indivíduo está prestes a despertar, porém ainda não atingiu plena consciência. Trata-se, portanto, do limiar entre o sono e a vigília: as imagens oníricas e as sensações deste instante não permitem os raciocínios cartesianos da vida acordada, vistos pelo narrador como grandes geradores de bloqueios. Enquanto acordado, o homem trava uma batalha com sua interioridade mais profunda, detendo-se a experimentar plenamente suas sensações e sentimentos. Deste modo, o instante que antecede o despertar é observado como um instante de libertação das defesas erigidas pelo próprio homem:

Los objetos muestran en el alba sus forma rígidas, y nosotros, a pesar de nuestras forma humanas, no tenemos, pálidos y con la boca abierta, nada de arrogantes. No existe dependencia ni servidumbre y yo no tengo conciencia de nada, ni aun de que existo; nada me pertenece y yo no pertenezco a nadie ni a nada (ROJAS, 1940, p. 41).

Jeanne-Marie Gagnebin, em "Entre sonho e vigília: quem sou eu?", o interessante posfácio da edição de Em busca do tempo perdido (2006), faz uma leitura das primeiras páginas do romance de Proust, tentando acompanhar "os tateios do sujeito em direção de si mesmo e do mundo, pelas palavras." (p. 542) A propósito da incerteza do personagem que não sabe se está dormindo, sonhando ou acordado, Gagnebin observa que Proust coloca em questão a própria estabilidade das coisas ditas reais.

Enquanto todo o projeto cartesiano "repousa sobre a preponderância da vontade do sujeito do conhecimento" (p. 552), Proust vai em outra direção, pois ao lermos Em busca do tempo perdido, percebemos que o involuntário afeta não somente a vida do corpo, mas em igual proporção, " a vida do espírito e do pensamento, a vida da memória, e isso não apenas porque seria um fator de desarranjo, mas porque o involuntário é constituinte da vida do espírito" ( $p$. $551)$. 
Podemos partir do estudo de Gagnebin para estabelecer paralelos entre 0 texto "Ensayo de la mañana" e as primeiras páginas de Em busca do tempo perdido. Em sua Antología Autobiográfica, Rojas confessa que fez várias tentativas de começar a escrever Hijo de Ladrón. Uma delas foi a publicação de "Ensayo de la mañana", na revista Babel. Mas sentiu que este texto não era o verdadeiro princípio, que deveria buscar outro, e por isso o deixou de lado. Um tempo depois, flagrou-se surpreendido, relendo o que havia escrito:

¿De dónde había sacado esa manera de escribir? ¿Dónde la había aprendido? ¿Por qué había cambiado tanto? (...) Todo ello daba la impresión de que, más que la descripción de los hechos, los seres y las cosas, me interesaba la sensación que producían. ¿Era bueno eso, era malo? No lo supe, pero me gustó (ROJAS, 1962, p. 98).

Ele descobriu então, com grande surpresa, que o resultado da escrita deste texto estava de acordo com seu modo natural de pensar, de divagar, de refletir e de recordar. Esta observação nos parece o eco de suas palavras em De la poesía a la revolución, onde comenta que o escritor da terceira fase só pode olhar para dentro de si mesmo quando fala das profundezas da consciência; mas ao mesmo tempo, encontra-se conectado com todo universo circundante. Afirma que seria natural dizer, do "Ensayo de la mañana", que havia inventado para si mesmo essa forma de expressão, mas sabe que não é bem assim: inconscientemente o escritor depende de outros, e mesmo que não se proponha a imitar, "su trabajo se enriquece con elementos o con recursos o con formas que halla en sus lecturas" (ROJAS, 1962, p. 99).

Que Rojas tenha ou não efetuado conscientemente essa apropriação transformadora da obra de Proust, tem, de fato, pouca importância para nós. Entretanto, é interessante ressaltar que a partir da primeira vez que leu o autor francês, confessou que o molde "estaba hecho y se llenaba rápidamente". Todavia, este molde somente foi assimilado porque dentro dele já havia, desde as primeiras leituras de Proust, potencial para tanto. Vejamos, a seguir, a impressionante semelhança dos fragmentos - nos dois autores - que tratam da zona limítrofe entre a consciência e a inconsciência de um "eu" que observa ao redor sem, no entanto, encontrar-se em estado de vigília: 
E antes mesmo que meu pensamento, hesitante no limiar dos tempos e das formas, tivesse identificado a habitação, reunindo as diversas circunstâncias, ele - meu corpo - ia recordando, para cada quarto, a espécie do leito, a localização das portas, o lado para que davam as janelas, a existência de um corredor, e isso com os pensamentos que eu ali tivera ao adormecer e que reencontrava ao despertar (PROUST, 2006, pp. 21-22).

Él tiene ya su conciencia y su memoria, sus armas y herramientas le han sido devueltas y sabe dónde está y qué hay a su alrededor: una mesa, una silla, la ventana, la puerta, cosas todas que existen fuera de él y, además, dentro de él, como un anticipo inútil, pues si esas cosas están donde están, ¿para qué, además, tenerlas adentro? (ROJAS, 1940, p. 45) 
A trama deste mundo é tecida pela necessidade e pelo acaso; a razão do homem se situa entre os dois e sabe dominá-los; ela trata o necessário como a base de sua existência; sabe direcionar, conduzir e aproveitar o acaso, e só enquanto se mantém firme e inabalável, é que o homem merece ser chamado um deus na Terra. Infeliz aquele que, desde a sua juventude, habitua-se a querer encontrar no necessário alguma coisa de arbitrário, a querer atribuir ao acaso uma espécie de razão [...] Só posso regozijar-me com o homem que sabe o que é útil a si e aos outros, e trabalha para limitar o arbitrário. Cada um tem a sua própria sorte nas mãos, como o artista tem a matéria bruta, com a qual ele há de modelar uma figura. Mas ocorre com essa arte como com todas: só a capacidade nos é inata; faz-se necessário, pois, aprendê-la e exercitá-la cuidadosamente."

\section{Goethe}




\section{- DIÁLOGO COM O GÊNERO PICARESCO -}

A trajetória do protagonista de Hijo de ladrón leva-nos a fazer relações com antecedentes literários, entre os quais o pícaro espanhol, que tem origem no século XVI. Para Wilma Maas, enquanto o surgimento da narrativa picaresca na Espanha pode ser vista como um modo de conscientização da desintegração do mundo feudal na Espanha, o surgimento do Bildungsroman se localiza na Alemanha da transição entre o feudalismo e a ascensão da burguesia (MAAS, 2000, p.71). A seguir, observaremos alguns destes paralelismos, observados na forma de narrar e no conteúdo do romance.

Mário González, em seu livro sobre o anti-herói, comenta que na Espanha dos Áustrias o modelo social tinha de ser o cavaleiro e o modelo econômico, seu modo de acumulação de riquezas pela conquista. As chances da burguesia de obter reconhecimento, nesse contexto, eram mínimas, pois mecanismos de ascensão social tais como o trabalho e a exploração estavam excluídos. Criou-se, assim, um vazio entre a nobreza e o povo, passível de ser preenchido pela esperteza, vetor de ascensão. González compara as condições para o surgimento de uma figura como a do pícaro, entre o citado momento histórico da Espanha dos Áustrias e a América Latina contemporânea. Ele constata que as analogias entre os dois períodos, relacionadas a questões de injustiça social, deixam claro que o trabalho, na atual conjuntura, não é o caminho adequado para a ascensão, mas a garantia do permanente empobrecimento. Deste modo, hoje, à semelhança daquele momento, a "alta burguesia produziu, com o capitalismo selvagem, um vazio entre ela e o povo, que mais uma vez não tem como enfrentá-lo, a não ser mediante a esperteza" (GONZÁLEZ, 1994, pp.14-18).

Em termos literários, o conceito de gênero picaresco que usaremos aqui está apoiado na noção baseada em três elementos básicos, defendida por González: "o anti-herói denominado pícaro, seu aventureiro projeto de ascensão social pela trapaça e a sátira social traçada na narração desse percurso" (Ibidem, p. 18). Para a delimitação deste conceito, González toma 
como referenciais as obras Lazarillo de Tormes, Guzmán de Alfarache e El Buscón. A partir desse cânone são extraídas algumas características como recorrentes no gênero, tais como as questões do trabalho, a aventura e 0 fingimento.

Para o pícaro, o trabalho é encarado como meio inevitável para matar a fome no início de sua trajetória. Como o objetivo é a ascensão social pelo mecanismo das burlas, à medida que consegue o mínimo para parecer um homem de bem, abandona progressivamente os afazeres laborais. Para González, "a aventura é o estado permanente do pícaro" (Ibidem, p. 267). Esta começa com o abandono do lar e cresce até a trapaça e o roubo, numa tentativa de equilibrar as chances desse personagem dentro de uma sociedade que o marginaliza.

Ao final da narrativa, o pícaro geralmente consegue o tão desejado lugar social de "homem de bem", por meio de um mecanismo de aparências. Através desse mecanismo, ele tenta convencer o leitor de que não vive mais em um estado de desonra no momento da enunciação, ulterior aos acontecimentos narrados. Todavia, sabe-se que "o pícaro é um permanente fingidor dentro da fiç̧ão, e seu fingimento serve exatamente para denunciar uma sociedade cujo denominador comum é a hipocrisia" (Ibidem, p. 269).

Tentaremos aqui observar em que medida o personagem Aniceto Hevia se aproxima do clássico pícaro espanhol, e em que medida se distancia dele. Tomando de empréstimo as palavras de Antonio Candido, em seu já consagrado artigo "Dialética da Malandragem", podemos comparar as características do personagem com as do típico herói ou anti-herói picaresco (CANDIDO, 1970, p.68.).

Entre os diversos traços característicos do gênero espanhol, podemos observar o elemento das andarias do protagonista, caracterizado pelas viagens - não raro internacionais -, devido à precoce e irreversível ruptura da estrutura familiar, e à tentativa de sobrevivência em condições adversas, tais como a fome e a convivência com amos cruéis. A pseudo autobiografia de um antiherói o define como um marginal da sociedade que narra suas aventuras, pondo em cena a síntese crítica de um processo de tentativa de ascensão social pela trapaça e representa uma sátira da sociedade contemporânea do século XVII. Nesse gênero, é através de sua condição servil que o pícaro 
perambula por diversos lugares e entra em contato com vários grupos e camadas sociais (GONZÁLEZ, 1994, p. 263).

Em Hijo de ladrón, ao ver-se sem pai e mãe, Aniceto e os irmãos são obrigados a procurar trabalho para sobreviver, mas o melhor que o menino consegue é o serviço de pregar botões em uma alfaiataria, em troca de almoço. Ainda em Buenos Aires, após constatar um dia que os irmãos não voltaram para dormir, e certo de que a situação vivida se torna insustentável, Aniceto abandona a casa e parte em direção ao bairro de Caballito, onde já havia morado com a família. Chegando lá, passa a viver na paupérrima casa do casal Bartola e Isaías. Nesse ambiente, quem dita as regras familiares a que todos se submetem é o manco Isaías, que o obriga ao trabalho escravo e à fome, e se alguma de suas determinações for contrariada, o menino - transformado em criado sujo e esfarrapado - é duramente açoitado com chutes proferidos pela perna de pau do amo. O nome bíblico do personagem - Isaías -, pode guardar aproximação com um procedimento do gênero picaresco por meio do qual, muitos amos têm nomes bíblicos e são inclusive - alguns deles - sacerdotes católicos. Apesar disso, e em contraste com as alusões cristãs de seus nomes, eles são déspotas, materialistas ao extremo, avaros e destituídos de qualquer piedade. O desfecho da relação de Aniceto com seu "amo" Isaías é bem semelhante ao de Lazarillo em relação ao amo cego na primeira parte do livro (Tratado Primeiro): uma brutal vingança, causadora de uma ferida aberta na cabeça do velho, e a fuga do jovem. Esses episódios são os que mais se aproximam de forma direta do gênero picaresco, em termos dos relacionamentos de Aniceto. Após isso, já não veremos personagens que cumpram a análoga função de 'amo' em sua vida.

No romance de Rojas, assim como no gênero picaresco, é o protagonista quem narra suas aventuras. Dentre as várias outras afinidades que o protagonista mantém com os pícaros clássicos, destaca-se também 0 traço de origem humilde, itinerante e ligado à contravenção social. Aniceto, além de ter por pai um renomado ladrão, vem de uma estirpe errante, sem endereço certo, como fica bem explícito na cena em que ele se encontra no Chile e deseja voltar para a Argentina, mas não tem sequer a quem escrever quando precisa de um documento que comprove sua nacionalidade. 0 narrador-protagonista explica que essa falta de raízes se dá pela profissão 
complicada e perigosa do pai - muito hábil no 'ofício' do roubo -, e que devia passar despercebido para continuar subsistindo com a família. Frustrado, o narrador - que assim como o Lazarillo, conta o passado com o filtro de uma visão crítica dos fatos ditada pelo presente e a experiência já vivenciada do velho - desabafa: 'gracias a esa habilidad no tenía yo a quien escribir' (HL p. 12).

O fato de ver-se largados no mundo ainda muito jovens serve de desculpa para que os pícaros tradicionais da Idade Média percam a ingenuidade inicial e cometam, sem pudor algum, atos tortuosos, dissimulados e trapaceiros, pois é o choque áspero com a realidade o fator decisivo de transformação do jovem ingênuo num indivíduo sem escrúpulos. Aniceto, em contrapartida, apesar de também vivenciar o desamparo e possuir uma certa ingenuidade inicial, não desenvolve uma natureza pícara como mecanismo de defesa.

Assim como alguns pícaros tais como o Lazarillo, ele é um protagonista solitário que se sente menos isolado quando consegue companhias, como a de Florentino Hernández, o pintor de rosto vermelho que the envia uma marmita na cadeia, por ocasião do motim já mencionado antes aqui; ou a do jovem amigo sem nome, dono de duas pequenas tartarugas - personagens aos quais faremos menção mais adiante. Todavia, se para o pícaro clássico as amizades têm caráter pouco duradouro por causa de seu projeto individualista destituído de compromisso social ou moral, em Hijo de Ladrón a causa da pouca durabilidade das relações não tem a ver com a superficialidade de um indivíduo apenas preocupado com seus interesses próprios. Na verdade, Aniceto separase dos amigos por causas representadas pelas leis da justiça vigente que tolhem, segundo o narrador irá pontuando de forma explícita no decorrer do texto, a liberdade de ir e vir. Assim, no caso do preso Florentino Hernández, porque foi posto em liberdade e ele não; já no caso do amigo das tartarugas, por possuir documentos que lhe permitem viajar para onde quiser, ao contrário de Aniceto, como observaremos mais adiante.

O nosso anti-herói é um desarraigado desde a infância, por causa das constantes mudanças de cidade. O narrador comenta que por ocasião da morte da mãe, o pai explica aos filhos que não podem contar com ajuda alguma, de parentes maternos ou paternos, pois todos estão mortos ou são 
muito distantes. Porém, naquele momento de luto, a presença da figura paterna no lar ainda garante alguma segurança aos quatro meninos. Após a prisão do pai, seguida do desmoronamento familiar, o protagonista sente-se completamente só, e vai com um grupo de homens para a colheita de milho no interior. Terminada a colheita, ao regressar a Buenos Aires, ele se pergunta: "¿Hacia quién volver la cara? Nadie me conocía y yo no conocía a nadie; en mi ciudad natal era un extraño, casi un extranjero" (HL p. 69).

Apesar desse sentimento de desamparo, até o incidente mencionado, relativo aos documentos necessários para o seu retorno à Argentina, o protagonista pensava ser um bonaerense, mas ele irá descobrir, de modo doloroso, que a sociedade normativa determina e classifica-o como um desterrado. O narrador comenta que em nome de um mecanismo burocrático, o funcionário público diz que precisa ver sua certidão de nascimento, e acrescenta, sarcasticamente: “(...) usted me trae sus papeles y yo le doy el certificado que necesita. Certificado por certificado. ¿Dónde nació usted?" (HL p. 7). A resposta é fornecida ao leitor pelo mecanismo do estilo indireto livre, através dos pensamentos do protagonista-narrador, que divaga sobre o fato irremediável de que ter nascido em Buenos Aires não possui valia alguma do ponto de vista legal: o importante são os papéis, sujeitos à falsificação, reflete ele. Este episódio, em meio a vários outros, da mesma natureza, nos faz observar que a realidade exterior (aqui, no caso, o diálogo com o funcionário), embora apareça como fato seguro, é apenas uma ocasião para o desencadeamento das digressões do narrador/protagonista, pois o grande peso que a narrativa ressalta repousa naquilo que é desencadeado, que não pode ser visto de forma imediata, e que não está preso ao presente do acontecimento periférico liberador (AUERBACH, 2009, p. 487).

Diante das ocorrências, Aniceto exprime sua indignação nessas divagações, e lamenta que o paradoxo sobre sua identidade chegue ao ponto de ser desacreditado em função de um carimbo. O narrador reflete que para os indivíduos desarraigados como ele, basta a palavra que afirme uma determinada origem. Resulta significativa a ênfase dada pelo narrador a essa indignação em negrito, como destacamos a seguir. O romance é permeado de digressões narrativas desse tipo que mostram um lastro da literatura engajada do criollismo e do narrador realista do século XIX: 
(...) indiferencia de la mayoría, se han apoderado de la tierra, del mar, del cielo, de los caminos, del viento y de las aguas y exigen certificados para usar de todo aquello: ¿tiene usted un certificado para pasar para allá?, ¿tiene usted uno para pasar para acá?, ¿tiene un certificado para respirar, uno para caminar, uno para procrear, uno para comer, uno para mirar? Ah, no señor: usted no tiene certificado; atrás, entiérrese por ahí y no camine, no respire, no procree, no mire.(HL p. 81)

Todas as digressões e raciocínios do narrador fazem alusão à noção clássica da picaresca espanhola, segundo a qual Antonio Candido em seu já mencionado artigo "Dialética da malandragem" (1970) destaca que, apesar de muitos pícaros serem amáveis e risonhos, não possuem sentimentos éticos e vivem ao sabor da sorte, esvaziados de profundidade psicológica. Ao final das contas, aprendem algo com a experiência, mas frequentemente terminam no universo do desengano e da desilusão. O narrador de Hijo de Ladrón não se põe no lugar de um mero ente movido pela causalidade externa, destituído de esfera psicológica. Ao contrário, junto ao seu poder de resistência diante das adversidades, ele não é um personagem alegre, mas sim, dado a elaboradas e profundas reflexões sobre os fatos vividos.

Antonio Candido observa que no romance picaresco clássico as classes são vistas a partir das camadas inferiores, em obediência ao sentido de ascensão, pela trapaça do personagem. No entanto, e apesar das semelhanças em certos aspectos com o gênero picaresco, Aniceto não se apresenta como anti-herói, pois não tenta ascender socialmente por meio de trapaças, nem permanece como um personagem servil em sua história; Os indivíduos que farão diferença substancial em sua vida estão mais próximos da figura de mentores que da de amos. Além disso, ao contrário dos pícaros que entram em contato com as mais diversas camadas sociais, os indivíduos na obra de Rojas aparecem na horizontalidade do mundo pobre.

De acordo com o especialista espanhol Antonio Rey Hazas, há uma antiga hipótese segundo a qual a picaresca é um gênero paródico dos livros de cavalaria. Se compararmos, por exemplo, o cavaleiro Amadis de Gaula com o 
Lazarillo de Tormes, na questão da origem, perceberemos que em ambos existe uma predestinação, embora em sentidos opostos. O primeiro possui origem nobre e o segundo é oriundo de um ambiente de desonra. Já em Hijo de Ladrón, o tema da escolha que se sobrepõe à predeterminação se apresenta na mescla da ascendência, representada pelo binômio honra (mãe)/ desonra (pai) (HAZAS, 1990, p. 49). Talvez seja por isso que no livro de Rojas a misoginia não se configure como ocorre com o pícaro espanhol. Mario González, em $A$ saga do anti-herói, comenta sobre o papel da mulher na Espanha católico-romana dos Áustrias. Naquela sociedade, o sexo estava sujeito à procriação, com o "consequente banimento oficial do erotismo" (GONZÁLEZ, 1994, p. 350). Desta forma, os autores da picaresca tinham consciência de que suas histórias somente teriam autorização para circular, se nelas fosse suprimido qualquer elemento erótico. Como resultado desta conjuntura repressiva, a mulher na picaresca clássica é reduzida ao papel de objeto, "cuja sexualidade só aparece para marginalizá-la duplamente."

Por outro lado, Ana María Plata Tasende, autora de um interessante dicionário de termos literários, comenta que a história narrada pelo pícaro, embora baseada em analepses, "avanza de acuerdo con una cronología linear, organizándose en episodios yuxtapuestos" (TASENDE, 2007, p. 480). Sabemos que, ao contrário, no livro de Rojas, uma das características marcantes é sua não linearidade narrativa, marcada por avanços e retrocessos temporais, mimetizando o fluxo dos pensamentos, tais como se apresentam na memória.

A seguir observaremos alguns traços de outro gênero consagrado, 0 Bildungsroman, e em que medida a obra de Rojas pode guardar aproximações com o mesmo. 


\subsection{ORIGENS DO BILDUNGSROMAN}

Marcus Vinicius Mazzari aponta dois princípios estruturantes para que uma obra se inscreva no gênero que tem nos Anos de Aprendizado de Wilhelm Meister (1795- 1796) de Wolfgang Goethe o seu modelo: o primeiro vai em direção a uma realização plena das potencialidades do indivíduo; o segundo aproxima-se de uma espécie de "teoria da socialização", preconizando-se a necessidade de interação estreita entre indivíduo e sociedade, o "eu" e o mundo (MAZZARI, 2010, p. 108).

Os estudiosos europeus, Karl Morgenstern (1770-1852) e Wilhelm Dilthey (1833-1911) são alguns dos primeiros especialistas que propuseram definições para o termo. Morgenstern, professor de estética e retórica na Universidade de Dorpat (atual Tartu, capital da Estônia), foi quem primeiro cunhou o termo Bildungsroman, numa conferência proferida em 12 de dezembro de 1819. O crítico fundamenta o emprego do termo não apenas por causa de uma certa unidade temática que vislumbra nesses romances - que devem tratar da formação do herói desde o início de sua trajetória, em direção a um nível de perfectibilidade -, mas também pela sua função social, isto é, estimular a formação do leitor (Ibid., pp. 98, 99).

Somente a partir de 1870 se deu de fato a difusão e consolidação do termo Bildungsroman - que designaria os romances que constituem a escola de Wilhelm Meister -, por meio do filósofo alemão, Wilhelm Dilthey, com a publicação de sua obra Leben Schleiermachers [Vida de Schleiermacher] (Apud, Mazzari, p. 97). Três décadas depois, avançando na definição do conceito proposto, Dilthey acrescenta em seu livro Das Erlebnis und die Dichtung [A vivência e a poesia] os seguintes termos:

Desde o Wilhelm Meister e o Hesperus, todos esses romances representam o jovem daqueles tempos; como ele ingressa na vida num alvorecer feliz, procura por almas afins, encontra a amizade e o amor, mas também entra em conflito com a dura realidade da vida e assim, 
sob as mais variadas experiências, vai amadurecendo, encontra-se a si mesmo e conscientiza-se de sua tarefa no mundo. (Ibid., p. 101)

Para Jacobs, existem alguns traços constitutivos para que uma obra seja considerada Bildungsroman, tais como uma consciência mais ou menos explícita, por parte do protagonista, de que ele próprio percorre não uma sequência aleatória de aventuras, mas sim um processo de autodescobrimento e de orientação no mundo. Além disso, a imagem que o protagonista tem do objetivo de sua trajetória de vida é, em regra, determinada por enganos e avaliações equivocadas, devendo ser corrigidas apenas no transcorrer de seu desenvolvimento. Por fim, o protagonista desse gênero discursivo tem como experiências típicas a separação em relação à casa paterna, a atuação de mentores e de instituições educacionais, o encontro com a esfera da arte, vivências intelectuais eróticas, experiências em um campo profissional e eventualmente também contato com a vida pública, política (JACOBS, 1989, p. 37).

Este trabalho propõe-se a indagar de que maneira se sustenta o estatuto literário em Hijo de Ladrón, impregnado de formas narrativas consolidadas, como o são a picaresca e o Bildungsroman, conceito este considerado tanto do ponto de vista literário quanto da formação histórico-discursiva. 


\subsection{PARADIGMA DO GÊNERO}

Víctor Escudero Prieto, pesquisador da Universidad de Barcelona, comenta que o século XVIII situa o indivíduo no centro de sua busca e questiona sobre o papel do mesmo em um contexto histórico de profundas mudanças sociais, entre as quais estão a queda do Antigo Regime e a emergência da burguesia como classe social. É aí que "la sustitución en el poder de una clase por la otra (...) conducirá a una nueva visión del ser humano en la que su esencia ya no vendrá determinada apriorísticamente por la pertenencia, sino que tendrá que ser conquistada. Es ahí donde el papel de la formación y de la autoconstrucción en el devenir temporal adquieren una profunda relevancia" (PRIETO, 2007, p. 9).

Em relação a essa temática abordada por Prieto, Wilma Maas comenta que, em um momento em que as aspirações burguesas orientam-se em direção à aquisição de cultura pessoal e do exercício da educação como forma de aperfeiçoamento do indivíduo, em um momento em que o indivíduo burguês torna manifesto seu impulso de superação da estreiteza de ideais inerentes à sua origem social em direção à possibilidade de "formação universal", o Bildungsroman surge como manifestação necessária dessa busca (MAAS, 2000, p. 51).

De acordo com Mazzari, o ideal utópico de formação de Os anos de aprendizado e a integração do herói na sociedade como fator necessário a esse ideal, ocorrem dentro do contexto social, político e econômico da sociedade alemã da segunda metade do século XVIII, pois nesse sentido, "O utópico revela-se assim como uma transcendência imanente, necessita de uma historicidade para poder afirmar-se" (MAZZARI, 1999, p. 73). Discorrer sobre utopia ajuda a esclarecer que a Sociedade da Torre e a conclusão do processo formativo de Wilhelm, coroada pelas palavras do $a^{2} a d^{7}{ }^{7}$, não representam a realidade histórica alemã da época, embora encontremos no enredo a mencionada transcendência em relação à história: antes representam uma

\footnotetext{
7 “-Glória a ti, jovem! Chegaram ao fim os teus anos de aprendizado; a natureza te absolveu."(p. 473)
} 
figura das tendências humanistas acalentadas por muitos na época, e que tornaram possível a revolução Francesa. Nesse sentido, Wilma Maas comenta que o romance de Goethe trata da rígida divisão em classes na Alemanha, bem como o papel reservado à incipiente burguesia. Por isso, os casamentos entre classes anunciados no fim do livro confeririam o status de equalização entre os personagens. Segundo a autora,

A palavra Bildungsroman conjuga, portanto, dois termos de alta historicidade no contexto alemão e mesmo europeu. Por um lado, a incipiente classe média alemã movimenta-se em direção à sua emancipação política, processo que se reflete na busca pelo auto aperfeiçoamento e pela educação universal. A par disso, cristaliza-se o reconhecimento público de um gênero literário voltado para a representação do próprio ideário burguês, gênero esse que o século XIX irá reconhecer como a grande forma do romance realista (MAAS, 2000, pp. 21-23).

Mazzari chama a atenção para o fato de que a evolução humana de Wilhelm Meister apresenta-se como um "estar a caminho" em direção a uma sabedoria de vida, e nesse processo existe uma tensão dialética entre o real e o potencial. O herói deseja o aperfeiçoamento humano e dispõe-se a buscá-lo, certo de que o caminho a ser percorrido encontra-se na vida artística - não na vida burguesa.

Todavia, o anseio de Wilhelm por alcançar essa enteléquia apresentase-lhe como uma conquista individual, e não tem nada a ver com abarcar o âmbito social no qual se insere. Sem que o saiba, a Sociedade da Torre exerce sobre ele uma preponderante influência que o leva a superar "suas tendências iniciais e, por fim, à reconciliação com a realidade social" (MAZZARI, 1999, p. 77). Embora a influência da Sociedade seja de essencial aporte na formação de Wilhelm, esta também decorre do cruzamento do personagem com inúmeros indivíduos que encontra pelo caminho, tais como burgueses, artistas, filósofos e aventureiros. Georg Lukács, no posfácio do romance de Goethe, discorre sobre esse aspecto da formação do protagonista em meio à coletividade, da seguinte forma: 
Vimos que o ponto de transição decisivo para a educação de Wilhelm Meister consiste precisamente em que ele renuncie a sua atitude puramente interior, puramente subjetiva, para com a realidade, e chegue à compreensão da realidade objetiva, à atividade na realidade tal como ela é. Os anos de aprendizado de Wilhelm Meister é um romance de educação: seu conteúdo é a educação dos homens para a compreensão prática da realidade. (p. 592)

Há críticos tais como os já mencionados Morgenstern e Dilthey, para os quais o Bildungsroman estaria ligado ao "conceito alemão de humanidade" e por isso se trataria de uma especialidade tipicamente alemã, uma projeção elitista da faixa de leitores contemporâneos de Goethe, no último terço do século XVIII (MAAS, 2000, pp. 48-49). Não obstante essa delimitação historiográfica, Wilma Maas comenta que há outras linhas teóricas, mais abertas, como a defendida por Jürgen Jacobs, em seu livro de 1989, que contesta a ideia de que o conceito esteja atrelado a um momento específico da narrativa em língua alemã. Para ele, a definição do termo Bildungsroman, dado o seu caráter geral e flexível, é capaz de abrigar a grande diversidade do conceito, que deve ser levado em conta através das diferentes épocas históricas, ultrapassando os limites de sua gênese, que se constitui, necessariamente, a partir do romance de Goethe. Wilma Mass enumera dentre o que Jacobs considera como características do gênero, elementos tais como a consciência mais ou menos explícita do protagonista de que suas vivências fazem parte de um processo de autoconhecimento. Uma segunda característica é a de que, geralmente, o percurso do protagonista é permeado por enganos e avaliações equivocadas, devendo ser corrigidas apenas no transcorrer de seu desenvolvimento. Por fim, "o protagonista tem como experiências típicas a separação em relação à casa paterna, a atuação de mentores e de instituições educacionais, o encontro com a esfera da arte, experiências intelectuais eróticas, experiência em um campo profissional e eventualmente também contato com a vida pública, política" Dentro deste raciocínio, a definição deste gênero se inscreve muito mais no âmbito do conteúdo do que no formal, e é por isso que não se pode considerá-lo apenas 
no exato momento de sua gênese, mas também através das diferentes épocas históricas (Ibid., pp. 62-63).

Walter Benjamin também se insere nesta linha de franqueamento dos limites estritos do gênero, pois, para ele, devem ser considerados romances de formação 'todos aqueles, enfim, que expõem a 'insuficiência' insuperável da existência humana no moderno mundo burguês (...)" (MAZZARI, 2010, p. 154).

Entre os extremos da delimitação ou ampla abertura conceitual, parece haver um caminho intermediário, no qual o romance de formação apresenta um tipo narrativo que tem como temática central a formação do indivíduo. Nesse contexto, não importa se a história narrada se dirige a um final harmônico, ou a um rotundo fracasso - Mazzari cita como exemplo, a primeira versão do Verde Henrique, do suíço Gottfried Keller. No segundo caso, em que a narrativa termina em fracasso, seu significado histórico consiste justamente em demonstrar a impossibilidade de formação nos moldes goethianos (op. cit.). 
Restam outros sistemas fora Do solar a colonizar. Ao acabarem todos Só resta ao homem (estará equipado?) A dificílima dangerosíssima viagem De si a si mesmo: Pôr o pé no chão Do seu coração Experimentar Colonizar Civilizar Humanizar O homem Descobrindo em suas próprias inexploradas entranhas A perene, insuspeitada alegria De con-viver.

\section{Carlos Drummond de Andrade}




\section{(A evolução dos relacionamentos humanos)}

Em Hijo de Ladrón é através da narrativa em primeira pessoa e pela mediação das vozes de três outras figuras que se dá a entrega do processo de autoconhecimento: um amigo que ele conheceu no Chile e que foi embora sem ele para Buenos Aires ('o amigo das tartarugas'), Cristián Ardiles e Alfonso Echevarría (o Filósofo). Além destes, há diversas micro-histórias de personagens que aparecem ao longo do livro, ouvidas enquanto Aniceto está na cadeia, como por exemplo o interessante relato acerca do inspetor policial Victoriano Ruíz. Observaremos a seguir como se dão as transformações operadas no protagonista desde o momento em que deixa o lar em Buenos Aires, até quando trava conhecimento com os personagens acima mencionados, que funcionarão como mentores.

Hijo de Ladrón é, em larga medida, a história do personagem Aniceto Hevia, não apenas como narrador-protagonista, mas como aquele sujeito que, partindo de uma vivência cheia de obscuridade e isolamento vai, aos poucos, encontrando os caminhos para tornar mais claras suas experiências, até chegar ao ponto de compreender-se a si mesmo e conseguir enxergar-se como indivíduo. Para tanto, Ihe é necessário partir de relacionamentos fragmentários e sem reconhecimento pleno, até encontrar-se com a alteridade nas figuras de Alfonso Echevarría e Cristián Ardiles. Somente depois de abrir-se com o outro é que será possível para ele adentrar na mais difícil exploração: sua própria interioridade. Portanto é interessante uma análise do teor das relações humanas que se desenrolam ao longo dessa sua 'viagem' de conhecimento pessoal.

Logicamente, as primeiras lembranças que o narrador tem de suas relações encontram-se no âmbito familiar e giram em torno da figura do pai que leva uma existência obscura fora de casa. Isto faz com que o menino, em sua imaginação, atribua a ele poderes quase mágicos: 
Durante aquellas horas lo imaginé marchando hacia el sur, no caminando ni viajando en tren, sino deslizándose a ras del suelo, en el aire, rápida y seguramente - tal como a veces me deslizaba yo en sueños -, inaprensible e incontrolable, perdiéndose en la pampa $(H L$, p. 49).

Já a partir dos oito anos o menino possui uma certa noção sobre o tipo de vida do progenitor, e com isso acaba aprendendo a ocultar-se dos demais, não dando lugar a relações bilaterais de transparência. Desta forma, mesmo enquanto criança, ele consegue ter a discrição necessária para frequentar escolas e morar em bairros residenciais sem que the escape dos lábios qualquer expressão que revele a 'estratégia econômica da família'. Depois que a mãe morre e o pai é preso, o contato entre os irmãos praticamente se desfaz, já que cada um deles passa a lutar por conta própria pela sobrevivência. Assim, um a um, os irmãos irão saindo de casa e não voltarão a se encontrar. Dá-se início, desta forma, a uma primeira ruptura: o afastamento do lar.

Todavia ao sair de casa, ele ainda busca um referencial conhecido, o bairro Caballito, lugar onde vivera há tempos com a família. Porém agora, rebaixado da condição de filho de um ladrão "renomado" à condição de órfão, encontra maus tratos e humilhações na casa do manco Isaías, outrora beneficiado com a ajuda ocasional do seu pai. Esta relação traumática com Isaías marca o momento de uma segunda ruptura, agora com os lugares e pessoas conhecidos durante a infância.

Após fugir da casa de Isaías, ao subir no trem junto com uns trabalhadores que vão para a colheita de milho no interior, o menino passa a responsabilizar-se pela própria sobrevivência. Porém, por causa de sua pouca idade, um destes trabalhadores mostra-se generoso com o jovem. Este tempo passado no interior servirá como preparação e fortalecimento para a série de privações que ainda estão por vir, fortalecimento esse que será exibido na aparência robusta adquirida por ele após o retorno da colheita: "Venía más erguido que al salir y mis manos eran como piedras" (HL, p. 69). Ao voltar a Buenos Aires perceberá, de fato, o rompimento com sua velha vida, ocorrido no momento em que subiu no trem: 
Fui a la que había sido mi casa: gente extraña vivía ahora en ella. Fui al Departamento de Policía: mi padre ya no estaba allí; tampoco estaba en la Penitenciaría. Fue trasladado a algún penal de la provincia y no supieron o no quisieron decirme adónde, se a Sierra Chica o a Bahía Blanca, antesala de Tierra del Fuego. Tampoco pude saber nada de mis hermanos. ¿A quién preguntar? ¿Hacia quién volver la cara? Nadie me conocía y yo no conocía a nadie; en mi ciudad natal era un extraño, casi un extranjero ( $H L$, p. 69$)$.

Assim é que o protagonista se lança ao mundo, convencido de que daquela cidade leva apenas suas lembranças,

Así salí al mundo, trayendo una madre muerta, un padre ladrón - condenado a muchos años de presidio - y tres hermanos desaparecidos (HL, p. 69).

Diante dos exemplos paterno e materno, o jovem resolve seguir o caminho da não criminalidade. Esta escolha parece estar ligada a um sentimento de culpa do protagonista, pois ele sente que, pelo fato do pai ser ladrão e sustentar a casa com esses rendimentos, toda a família tem uma dívida com a sociedade:

Había pasado malos ratos, es cierto, pero me pareció natural y lógico pasarlos: eran quizá una contribución que cada cierto tiempo era necesario pagar a alguien, desconocido aunque exigente, y no era justo que uno solo, mi padre, pagara siempre por todos. Los cuatro hermanos estábamos ya crecidos y debíamos empezar a aportar nuestras cuotas, y como no podíamos dar lo que otros dan, trabajo o dinero, dimos lo único que en ese tiempo, y como hijos de ladrón, teníamos: libertad y lágrimas ( $H L$, p.12).

Essa sensação de culpa vem junto com um sentimento de vergonha com relação à sociedade, um sentimento de inadequação e de sujeira, explicitado no episódio do bêbado com as nádegas cobertas de excremento, à mostra:

(...) se me figuraba que también estaba como él, con las piernas y el trasero al aire, que su trasero y sus muslos eran los míos y los de todos los hombres (HL, p. 105). 
Além dessas observações, devemos lembrar que o personagem é muito ligado à mãe durante a infância e está sozinho com ela em casa quando ambos são levados presos, sem terem cometido delito algum. Ao afastar-se de Buenos Aires, caminha em direção ao Chile, país da mãe, em uma tentativa precária de religar-se ao seio materno. No trajeto atravessa a Pampa trabalhando como ajudante de carpinteiro, de pedreiro e de mecânico. Toda esta viagem ao Chile pela Cordilheira nos lembra a viagem do próprio Rojas durante a adolescência.

Ao chegar em Mendoza, Aniceto conhece um homem (que se diz vegetariano e discípulo de Schopenhauer) com o qual aprende o ofício de pintar muralhas, portas e janelas. Depois disto, parte em direção à Cordilheira, contratado como ajudante de carpinteiro junto com um grupo de trabalhadores da Ferrovia Transandina. Segundo as palavras do narrador: "Me acercaba a Chile, la tierra escondida" ( $H L$, p. 70 ). Esta tierra escondida pode assumir a conotação da origem desconhecida de Rosalía, sua mãe, que corta todos os laços com o passado no momento em que vai viver com o fora da lei Aniceto Hevia. A outra conotação está em considerar o Chile como uma alegoria do útero materno, ao qual retorna para esconder-se das adversidades sobrevindas, já que ouvira sua mãe contar "los más dulces cuentos sobre Chile" (HL, p. 81). Sabemos que a referência ao objeto perdido, pela repetição, é antiga em Lacan e permanece como um eixo fundamental na sua obra. No entanto, essa repetição está destinada ao fracasso:

$\mathrm{Na}$ medida em que o que se apresenta a ele só coincide parcialmente com aquilo que the proporcionou satisfação, o sujeito se põe em busca e repete indefinidamente sua procura até reencontrar este objeto. $\mathrm{O}$ objeto se encontra e se estrutura pela via da repetição reencontrar o objeto, repetir o objeto. Só que nunca é o mesmo objeto que o sujeito encontra (LACAN, 1992, pp.131-132).

A mãe, objeto perdido para o protagonista, tem uma origem incerta, já que tudo que ele sabe a seu respeito é que "era originaria de algún punto de la costa de Chile central, regiones a que no llegan sino débiles rumores del mundo" (HL, p. 194). Na errância do próprio Aniceto observamos uma repetição oriunda do anseio pela origem. Porém o retorno e o pleno reintegrar-se às 
origens tornam-se impossíveis para ele porque em sua vida há entes mortos, coisas destruídas e um passado sustentado apenas pelas lembranças ${ }^{8}$. Neste sentido, sua busca fracassará, mas nem por isso ele encerrará a repetição: quando o livro termina, ele se encontra a caminho de um lugar novo.

No processo de gestação de identidade, agora se distanciando da figura paterna e do estigma de "filho de ladrão", resolve silenciar a respeito de suas origens. Deste modo, estabelece relações unilaterais nas quais, mesmo quando conhece as histórias dos outros, não se deixa conhecer pelos mesmos, como se observa no seu encontro com o basco, o vagabundo das tartarugas, o pintor apelidado 'Azarcón' e os presos que conhece, por ocasião do motim.

Quando, ainda em Mendoza, Aniceto encontra perto de uma fonte um homem que se diz basco, o que acontece aí não é precisamente um relacionamento de encontro entre dois indivíduos: está mais para o deslumbramento do jovem por um símbolo, que o faz remontar à Buenos Aires de sua infância. Percebemos que este homem, por sua nacionalidade espanhola, reconstitui, para o jovem, a presença do pai, também espanhol. Na verdade, ao encontrar-se com o basco, Aniceto encontra consigo mesmo nos dias reconfortantes de sua infância, quando a existência era protegida e o sustento, certo. Tanto que os biscainhos daqueles tempos vendiam leite, elemento índice de amparo:

¡Un vasco! Conocí muchos, allá, en mi lejana Buenos Aires, pero éstos, lecheros todos, de pantalones bombachos y pañuelo al cuello, desaparecieron junto con mi infancia y no tenían nada que ver con éste, encontrado por mí en una plaza pública: este vasco era mío (...) $(H L$, p. 8)

O jovem fica absolutamente encantado porque, após alimentar aquele homem com cachos de uvas, pede-Ihe que pronuncie algumas palavras em seu idioma natal, e para seu deslumbramento, o outro canta ("cantó, sí, cantó"

\footnotetext{
${ }^{8}$ Isto nos faz acudir à memória o seguinte fragmento da obra de Proust: [...] Mas quando mais nada subsista de um passado remoto, após a morte das criaturas e a destruição das coisas, sozinhos, mais frágeis porém mais vivos, mais imateriais, mais persistentes, mais fiéis, o odor e o sabor permanecem ainda por muito tempo, como almas, lembrando, aguardando, esperando sobre as ruínas de tudo o mais. Proust, No Caminho de Swann, pp. 50-51
} 
$H L$, p.8). Por meio da música, dessa cantiga popular, o órfão consegue momentaneamente libertar-se da estreita e dura realidade.

Num dia, à margem do rio Aconcágua, conhece um jovem alguns anos mais velho que a primeira vista desperta-lhe atenção por não parecer um vagabundo típico: é dono de duas pequenas tartarugas, como já se disse antes, usa óculos do tipo "pince-nez" e veste roupa quase nova. Após o estranhamento do início, Aniceto ouve do rapaz que é natural de Santiago, no Chile. Mesmo apesar de praticamente ainda não se conhecerem, o jovem apieda-se dos pés feridos de Aniceto e o presenteia com um par de alpargatas que leva na mochila. Para Aniceto, os seis ou sete anos a mais do amigo eram admiráveis, pois "representaban una gran porción de experiencia y de conocimientos" ( $H L$, p. 105), e assim é que se tornam amigos, até o dia em que, ao planejarem ir a Buenos Aires, Aniceto descobre estar proibido, por falta de documentos: o amigo embarca, e ele fica novamente só no Chile, onde se vê envolvido num motim que o levará a prisão.

É interessante observar que o amigo das tartarugas, apesar de não nomeado, ocupa parte significativa da narração. Há diversas similaridades entre os dois personagens, além de algumas diferenças que podem ser observadas como geradoras de afinidade de Aniceto em relação a ele. Este jovem, assim como Aniceto, vaga por diferentes lugares e perdeu a mãe. Todavia, como é alguns anos mais velho, ocupa a figura heroica de um irmão a quem se admira. Talvez isso ocorra porque ao contrário de Aniceto, que é obrigado a encarar o grande mundo por já não ter para quem retornar, esse vagabundo atípico anda a esmo por escolha, visto que sempre tem a possibilidade de escrever ao seu pai, pedindo dinheiro para o regresso, como quando por se encontrar com uma aparência lastimável, recebe uma esmola e percebe que já está na hora de voltar para casa. Já Aniceto, mesmo na ocasião da morte de sua mãe, quando se aventa, em sua casa, a possibilidade de receber ajuda de algum parente, a resposta de seu pai é a seguinte: "no tengo un solo gato que me maúlle, fuera de ustedes" (HL, p.58).

Deste modo, podemos observar que ao mesmo tempo em que se identifica com o amigo pelas andanças, Aniceto e ele representam uma espécie de espelho invertido: o ladrão Aniceto Hevia deseja que os filhos se tornem profissionais estudados e respeitáveis sem lhes fornecer uma base para tal, 
sendo o fim disto o já sabido irremediável desamparo de sua descendência. Por outro lado, é justamente por causa do pai, um professor culto que tenta fazer dele uma pessoa esclarecida, que o desinteressado amigo de Aniceto é espantado de casa, como podemos observar:

¿Qué hacer? Todo cansa, pero más que nada las matemáticas. Pensé en el mar: ¿habría allí álgebra, geometría, declinaciones, ecuaciones de primer grado, decimales, verbos auxiliares y sepa Dios qué más? Quería horizontes, no muy amplios porque soy medio cegatón, pero más extensos que los que me permitían los muros de la sala de clases y los bigotes del profesor de francés. Me fui, pues, hacia el mar (HL, p. 44).

No mundo, o vagabundo passa por diversas aventuras que são detalhadamente contadas pelo narrador. Em meio aos seus relatos, vão se exibindo diversas ancoragens históricas, tais como a influência inglesa sobre a população chilena no episódio paródico em que, empregado como policial em Punta Arenas e guardando um louco italiano, ele está lendo o romance La Cuchara de Plata, do romancista inglês John Galsworthy, e está tão absorvido pela leitura a ponto de continuar lendo enquanto é atacado, com medo de perder o final. Se observarmos o louco italiano, percebemos que ele se apresenta como índice da angústia dos imigrantes distantes de sua terra natal: é um dono de armazém que deseja sem sucesso voltar para a Itália, pois não consegue desfazer-se do estabelecimento comercial. No desespero por se ver longe daquele fim de mundo gelado onde foi parar, ateia fogo no próprio negócio.

Além dessas passagens citadas, quando lemos a narrativa da passagem do jovem míope em Buenos Aires, também podemos observar a ancoragem histórica dos imigrantes europeus e hispano-americanos que chegaram naquela cidade:

Era aquél un albergué de vagabundos, pero de unos vagabundos muy especiales: entre ellos se encontraban hasta individuos que tenían cuentas en las cajas de ahorros y en los bancos. Allí dormían personas de los dos hemisferios y de levante y de poniente: españoles y chilenos, yugoslavos y peruanos, italianos y 
argentinos; algunos que andaban en parejas, solitarios otros, sin que ninguno fuera lo que la gente llama un vago; es decir, un hombre que por un motivo u otro no quiere trabajar; al contrario, tenían oficio y hasta profesiones; zapateros, por ejemplo, como el chileno Contreras, y abogados, como el español Rodríguez (HL, p.51).

De acordo com a Dirección Nacional de Migraciones de la República Argentina em 1970, a Argentina recebeu 6 milhões de estrangeiros entre o final do século $\mathrm{XIX}$ e a primeira metade do século $\mathrm{XX}$, a maioria deles italianos e espanhóis. Em 1869 os estrangeiros já representavam 12\% da população nacional, numa população de apenas 1.800 .000 habitantes. Em 1914 os estrangeiros chegaram a compor $30 \%$ da população da Argentina e $60 \%$ dos habitantes de Buenos Aires. Na verdade, ao observarmos personagens tais como os apresentados no 'albergue', nos vemos diante da visão subjetiva de Rojas, que exibe à 'boa sociedade leitora' que, ao contrário do senso comum, nem todo morador de rua pertence ao universo da delinquência ou vagabundagem. $O$ próprio jovem míope representa uma faceta anárquica na medida em que rompe com as expectativas de normalidade esperadas e vive uma experiência de libertação em suas andanças, juntamente com o seu repúdio à obtenção de dinheiro como objetivo de vida, como podemos observar na ojeriza demonstrada pelo companheiro de 'albergue' que trabalha incansavelmente a fim de enriquecer, como podemos observar no trecho a seguir:

Le tomé antipatía: todo lo reducía a nacionales y no disimulé mi regocijo cuando supe que tenía embarque para Punta Arenas; por allá debe andar todavía, buscando dinero hasta por debajo de la bosta de los animales ( $H L$, p.51).

Porém pode-se dizer que esse jovem é um elemento anárquico bem intencionado, mas imaturo, pois seu modo libertário de pensar possui alcance apenas para si próprio, e mesmo assim ainda se encontra ligado ao universo de normas do qual quer se isentar, pois como já vimos, diante das dificuldades, sua saída é a de pedir socorro ao pai e retornar ao lar. Na verdade, seu modo 
de vivenciar as experiências nos faz lembrar a seguinte citação de Wilde sobre o individualismo:

Com a abolição da propriedade privada, então, nós teremos um verdadeiro, lindo, salutar Individualismo. Ninguém terá que perder sua vida acumulando coisas, e símbolos por coisas. Todos viverão. Viver é a coisa mais rara no mundo. A maioria das pessoas existe, e isso é tudo (WILDE, 1891, p.9).

Mesmo assim, percebemos que neste encontro existe uma ligação humana que ameniza o sentimento de tantas perdas, pois Aniceto o chama de amigo e beneficia-se duplamente: primeiro porque o rapaz, ao vê-lo com os pés feridos, se compadece e o presenteia com sandálias novas; segundo, porque ao the narrar suas experiências, enriquece o universo de conhecimento de nosso herói, que em retribuição, Ihe oferece apenas a sua companhia nas andanças e um absoluto silêncio acerca de suas origens. Sozinho novamente, vagando pelas ruas, ainda a pensar no amigo das tartarugas que partiu, Aniceto é de repente obrigado a correr da polícia junto com uma multidão, sem ao menos saber do que se trata. Horas mais tarde, sabendo que se trata de um motim popular causado pelo aumento das passagens dos bondes, mistura-se ao povo que se manifesta e toma o partido das massas, posicionando-se contra a autoridade:

Cuando iba justamente en mitad de una de las calzadas, sentí un griterío; me di vuelta; dos policías a caballo llevaban un hombre. Lo miré; le habían pegado o había caído y su cara estaba llena de sangre. Mecánicamente también, sin pensar en lo que hacía, terminadas todas mis reacciones mentales, me incliné, recogí una piedra y la lancé con todas mis fuerzas hacia uno de los policías (HL, p. 103).

O narrador manifesta, já vimos, as posições ideológicas anárquicas do próprio Rojas. A manifestação de rebeldia não fica impune e o jovem é acusado pelo roubo a uma joalheria com o qual é submetido na prisão, a passar meses dormindo no chão frio até contrair uma pneumonia. 
Se a relação do personagem com a justiça é de humilhação e descaso, não se pode dizer o mesmo quando se trata de sua ligação com outras pessoas de sua classe social. Um exemplo disto é a solidariedade que the manifesta Florentino Hernández, um pintor de rosto vermelho apelidado Azarcón, que se encontra entre os presos em meio à confusão dos bondes e promete ao menino que vai pagar sua fiança, certo de que ambos serão condenados por embriaguez. Todavia, quando sai da cadeia e se dá conta de que não tem como cumprir a promessa, envia-lhe uma marmita quente e fresca que ficará marcada na memória do protagonista.

Além do Azarcón, na cadeia o jovem tem contato com diversas histórias de vida que lhe ajudam a formar juízos de valor sobre as relações de autoridade e de hierarquia social. Nas conversas ouvidas, chama-lhe a atenção que os presos conversem sobre suas vidas e suas pendências judiciais com a naturalidade de qualquer trabalhador a comentar sua profissão. Uma das histórias que se expandem na narrativa com mais detalhe, e que serve certamente como alegoria geral da complexa relação entre a ordem e a desordem no romance é a de Victoriano Ruiz. Trata-se de um rigoroso inspetor policial de estação de trem, a quem se considerou durante muitos anos como a "pesadilla de los ladrones de cartera" (HL, p. 27). Depois de anos de severa condução da ordem na estação de trens, a partir de suas experiências com ladrões de carteira e criminosos de meio porte, ele percebe que existe uma identificação, em termos humanos, entre polícia e bandido e se afasta dos seus princípios morais, a ponto de se corromper.

Os rígidos princípios do inspetor serão desestabilizados por dois ladrões: Víctor Rey e El Camisero. De Víctor Rey se diz que "no parecía un señor: parecía un príncipe", pois é apresentado como alto, elegante e vestido à moda francesa. É o tipo de ladrão que se mistura aos ricos, sem que ninguém jamais suspeite de suas intenções. $O$ narrador diz que $O$ elemento desencadeante para que Victoriano saia definitivamente de sua condição de policial é o encontro com "El Camisero, ladrón español, célebre entre los ladrones, hombre que a las dos horas de estar detenido en una comisaría, tenía de su parte a todo el personal, desde los gendarmes hasta los oficiales(...)" (HL, p. 32) 
É interessante notar, no discurso do narrador, uma admiração implícita pelos ladrões não violentos, deixando patente o imaginário popular de admiração pelo 'banditismo heroico'. Os historiadores chilenos, Daniel Palma e Marcos Fernández, comentam em Historia de la vida privada em Chile, que apesar da mídia nascente da segunda metade do século XIX tentar exibir os delinquentes como seres repulsivos, muitos destes eram transformados em heróis populares pela literatura romântica da época:

Para los escritores románticos, el delincuente representa al hombre que no ha renunciado a su libertad, ni a su gloria, aunque sea pasando por el patíbulo... El infractor de las leyes aparece como un hombre que no se adapta a la mediocridad del mundo que se está construyendo, ni al orden legal que lo estructura, y salta por encima de convenciones y leyes. Apud. Palma e Fernández ( 2005, p. 237)

O tempo passado na cadeia serve para assentar, no protagonista, conceitos tais como alteridade - em suas relações interpessoais - e uma consciência mais nítida acerca dos mecanismos opressores de dominação. Lembremos que este livro se insere num momento histórico, em Hispano-América, quando a mobilização intelectual da esquerda se fazia presente de diversos modos. Com Rojas, influenciado pelo ideal anárquico, não foi diferente: o narradorpersonagem Aniceto Hevia deixa à mostra as motivações ideológicas do autor.

A história do policial Victoriano Ruiz é lembrada por Aniceto justamente porque aquele homem, que sempre viveu do lado da ordem, passa por imensas mudanças de paradigma, ao reconhecer, na sua experiência, a tênue fronteira moral entre policiais e bandidos. Do mesmo modo, Aniceto, que desde criança transita entre os universos da ordem e da desordem, acaba passando pela revisão de muitos preconceitos ao se deparar com as contradições humanas. Usaremos, a seguir, a expressão 'ordem e desordem', proposta por Antonio Candido na "Dialética da malandragem".

Podemos observar que no arranjo familiar de Aniceto encontra-se 0 binômio pai ladrão e esposa exemplar, ambos convivendo numa sociedade de normas, porém a o mesmo tempo afastados dela. Ao dissolver-se a família, o filho rompe as expectativas sociais esperadas, escolhendo a pobreza ao invés da delinquência, mas ao mesmo tempo firma-se na instabilidade social. Nesse 
sentido, se torna possível uma interpretação dialética a partir das contradições, o que nos lembra a ótica surrealista bretoniana, que propõe o desregramento como regra. Manuel Rojas, ao afastar-se do criollismo, incorporou alguns elementos surrealistas em seus escritos, elementos estes que podemos observar na construção narrativa de Hijo de Ladrón, tais como misturar autor e obra, a alinearidade narrativa (que aproxima a escrita da associação livre de ideias), a aproximação de realidades distantes e a disponibilidade.

Dentro da visão surrealista bretoniana, é se perdendo que os indivíduos se encontram, posto que a única certeza é a realidade, e o homem produz uma realidade mutável e sempre evidente. De acordo com este pensamento, a imagem poética "não pode nascer da comparação, mas da aproximação de duas realidades mais ou menos remotas. Quanto mais longínquas e justas forem as afinidades de duas realidades próximas, tanto mais forte será a imagem - mais poder emotivo e realidade poética ela possuirá" (BRETON, 2001, p.10).

Assim, é possível referir-se à união dos pais de Aniceto como uma síntese entre os universos da ordem e da desordem, em que se explicita a existência de comunicação entre estes dois hemisférios distintos. É assim que o pai de Aniceto, apesar de ladrão, é descrito pelo narrador como pacífico e sério:

(...)Cuando pienso en él -me pregunto: ¿por qué? Más de una vez y a juzgar por lo que le buscaba la policía, tuvo en sus manos grandes cantidades de dinero; era sobrio, tranquilo, económico y muy serio en sus asuntos $(H L, p .12)$.

Mesmo a honrada Rosalía possui uma origem incerta e sabe dissimularse como mulher frágil diante da polícia:

Mi madre, próxima a dar a luz, fue llevada por el abogado ante el tribunal y allí no sólo aseguró todo lo que el ente jurídico le indicó que asegurara, sino que lloró mucho más de lo aquel le insinuara. (...) La voz de mi madre tornó a hacerse tierna, como si quisiese persuadir, por medio de su ternura, a aquel hombre: - Ya le he dicho que no sé dónde está; desde ayer no viene a casa (HL, pp.12-16). 
Em outra passagem, o narrador enciumado dá a entender que sua mãe se apaixona pelo belo falsificador loiro (Nicolás), na ocasião em que seu marido se encontra na cadeia, no início do casamento. Acontece que Nicolás vai à sua casa, apresenta-se arrumado como um homem da lei, tranquiliza Rosalía (grávida do primeiro filho) dizendo-lhe que o marido deve sair logo da cadeia e deixa-Ihe um maço de dinheiro falsificado para livrá-la do apuro financeiro em que se encontra: "Mi madre quedó deslumbrada por aquel individuo, y aunque no volvió a verle sino detrás de una corrida de barrotes y de una fuerte rejilla de alambre, vivió deslumbrada por su recuerdo" (HL, p.9).

Estes trechos citados fazem lembrar Antonio Candido, que "as pessoas fazem coisas que poderiam ser qualificadas como reprováveis, mas também fazem outras dignas de louvor, que as compensam. E como todos têm defeitos, ninguém merece censura (...) A repressão moral só pode existir fora das consciências. É uma questão de polícia(...."”9 Pode-se dizer que se trata de libertar-se da "repressão mutiladora da personalidade" (CANDIDO, 1970, p. 21).

Se o romance picaresco mostra a decomposição feudal, e o Bildungsroman - que tem Os anos de aprendizado como paradigma -, aponta para a descontinuidade da aristocracia latifundiária, talvez Hijo de Ladrón possa acenar para uma descontinuidade da ordem social chilena, em direção a uma experiência mais libertadora. No livro, há uma ordem desejável, mas ela se processa no âmbito da população segregada da sociedade. Se na sociedade tradicional impera o binômio ordem e desordem, na sociedade ideal de Rojas há o que se poderia chamar de $3^{\text {a }}$ margem, a de uma ordem aspirada, em que a convivência harmônica entre o que se apresenta diverso e a não dominação de um indivíduo sobre o outro se encontrem como pilares. Para que estas aspirações tomem corpo e sejam exercidas não há necessidade que o indivíduo faça parte das tradicionais disposições de conveniência do Estado: a anarquia aparece aí como um vetor através do qual esse ideal poderia se consolidar. A seguinte fala do narrador protagonista exibe seu inconformismo com a situação em sociedade:

\footnotetext{
${ }^{9}$ Ver “Dialética da Malandragem”, pp. 20-21
} 
El hombre aguijonea al hombre, cosa que no hace el buey con el buey: nada de prisa, no te demores, el cliente espera, lleva esto, trae lo otro, hazme lo de más allá, despacha aquello, y aguijoneando a los demás se aguijonea a sí mismo (HL, p.232).

O excerto anterior faz vir à memória a aspiração utópica mencionada por Eduardo Colombo, segundo o qual "segundo o célebre mito que Platão atribui ao sofista no Protágoras, os homens não poderiam viver em sociedade sem a arte da política, e para poder exercê-la, cada um deles disporia de uma parte igual de aidôs (o reconhecimento e o respeito do outro) e de dikê (o senso da justiça)" (COLOMBO, 2003, p. 12).

Outro dos elementos surrealistas presentes na obra é o estado de disponibilidade, categoria chave de Breton, que tem valor equivalente ao elogio da distração. Andar ao acaso sem objetivo definido é um meio de conhecimento importantíssimo e apresenta um paralelo com a escrita automática, por ser a mesma coisa no plano da escrita (já que é levar-se pela escrita ao flanar). Como diria a personagem Nadja, no romance de mesmo nome, "não existe passo perdido". Nesse sentido, o andar errante de Aniceto pode ser observado num paralelo com a escrita automática e a associação livre de palavras. O seu deslocamento físico desorientado corresponde, no plano psicológico, ao deslocamento mental que se vai operando em direção a seu processo de crescimento humano: é se perdendo que ele vai se encontrar:

No me quedaré siempre aquí. El hombre no se quedará en ninguna parte; se irá siempre, alguna vez para no volver; también alguna vez el pulmón dejará de dolerme y de sangrar y podré irme, irme, irme, irme; parece una orden, una consigna, un deseo, una ilusión y hasta puede ser una esperanza. El que desea irse no necesita nada, nada más que una oportunidad para hacerlo..." (HL, p. 214)

Seguindo o caminho de autoconhecimento, a estada no cárcere possibilita que Aniceto trave conhecimento com os mais distintos tipos humanos e desmistifique vários conceitos formados enquanto se via na esfera protegida do lar. Ele somente é posto em liberdade porque no hospital da 
prisão, onde está internado, chega um preso em piores condições de saúde, e portanto ele já não pode ocupar o leito.

Ao sair da prisão em Valparaíso, fraco e com fome, desce as ruas em direção à região do porto, que conhecera antes de ser encarcerado. Ao avistar o mar, detém-se num murinho de pedra, a observar a praia. Dali avista alguns pescadores, que trabalham e conversam em volta de um barco, além de dois homens, que andam "de acá para allá y de allá para acá, una y otra vez, inclinándose de cuando en cuando a recoger algo que examinaban y que luego guardaban en sus bolsillos o arrojaban hacia un lado u otro" (HL, p. 81). Desce, então à praia, por uma escada de pedra. Explica ao leitor que desceu devagar os degraus, sem apressar-se, como se em cada um deles seus pés encontrassem algo especial, até que chegou à areia, ponto em que é interessante seguir o olhar do narrador, no trecho a seguir:

Desde allí volví a mirar; a la derecha se levantaba, sobre una elevación rocosa, la estatua de un San Pedro, de tamaño natural, con su túnica de grandes pliegues y su calva de apóstol. Esta calva era, cosa curiosa, de color blanco en oposición al resto del cuerpo, de las manos y de la cara - ya que no se veía otra parte, excepto las puntas de los pies -, que era gris verdoso; el manto mostraba también aquí y allá manchas blancuzcas. ¿Por qué y de dónde aquel color? Una gaviota se erguía sobre la cabeza del santo, haciendo juego con otra, posada, unos metros más allá, sobre el penol de un mástil que debía tener algún fin patriótico (HL, p. 195).

A observação do santo e do monumento patriótico - defecados por pássaros -, além de carregar um sentido irônico de desprezo pelas tradicionais instâncias Pátria/lgreja, pode ser vista como uma analogia histórica em relação ao guano, no que ele representa com relação às origens do conflito bélico da Guerra do Pacífico. Laura Hosiasson comenta o lamentável fato de que a Guerra do Pacífico, travada no momento de consolidação das nações recéminauguradas (Peru e Bolívia contra o Chile), deu-se fundamentalmente por causa da preponderância econômica dos interesses europeus sobre a região. Durante milênios - antes da chegada de Humboldt, em 1802 -, o guano depositou-se em toda a costa boliviana e do sul do Peru. "No entanto, será só a 
partir do interesse econômico despertado na Europa que o Chile, a Bolívia e o Peru vislumbrarão nele a possibilidade de incrementar suas economias nacionais, estas por sua vez também construídas à imagem e semelhança do modelo franco-inglês" (HOSIASSON, 2011, p. 157). Quando o guano deu mostras de esgotamento foi substituído pelo salitre. Em nome da avidez por desenvolver a economia local, milhares de vidas humanas foram sacrificadas pelo caminho. A triste ironia deste episódio se encontra no fato de que, algumas décadas após a Guerra do Pacífico (em 1930) um laboratório alemão desenvolveu um fertilizante sintético que passou a substituir de modo definitivo o salitre. De acordo com as palavras de Hosiasson, "a Guerra do Pacífico é um contrassenso, assim como também o é, observado de longe, a luta de um punhado de homens à procura de um fétido elemento orgânico que, finalmente após o confronto e a morte, perderia todo o seu valor simbólico, transformando o episódio num dos muitos paradoxos com que se constrói a comunidade imaginária da nação" (Ibidem, p. 161).

Mas não nos é o caso aqui de entrar em detalhes acerca do guano. No momento em que o protagonista se vê, na praia, diante da estátua de São Pedro (alegoria da porta de entrada para o céu) e do monumento pátrio, ambos defecados por aves marinhas, é possível estabelecer algumas considerações.

Sabe-se que no imaginário popular existe um entrelaçamento entre os poderes divino e terreno. Neste sentido, Laura Janina Hosiasson comenta, com relação ao herói clássico-romântico que ele "é sempre um ser devoto que concebe a pátria como um lugar sagrado e sob a proteção de Deus" (HOSIASSON, 2011, p. 48). Ora, Aniceto Hevia não é exatamente um 'herói' de acordo com os conceitos romântico-realistas da literatura do século XIX, e o seu desgarramento e a sua condição de ex-presidiário e apátrida o tornam um anti-herói moderno. Certamente o binômio encomiástico Deus/Pátria não lhe serve. Mas sabemos que não foi sempre assim: durante seu período de inocência, o protagonista não faz ideia de quão afastado se encontra dos valores tradicionais da cidadania. Foi-lhe necessário cair no grande mundo, ter o trânsito impedido por causa da falta de documentos, ir preso por haver se posicionado ao lado de uma causa popular (e condenado pelo desconhecido assalto a uma joalheria), para chegar à constatação de que sua existência deve seguir à margem da sociedade que o exclui: sua caminhada à beira-mar, a 
observar a praia fétida e cheia de detritos apresenta-se como uma metáfora de sua própria condição social de marginal:

Seguí mirando; los dos hombres daban la impresión de que eran nacidos en aquella playa llena de cabezas de sierra, tripas de pescado, aletas de azulejos, trozos de tentáculos de jibia y tal o cual esqueleto de pájaro marino: hediondo, además, a aceite de bacalao y decorada por graves alcatraces (HL, p.196).

O momento em que Aniceto avista, pela primeira vez, a dupla Cristián e Echevarría, é quando se lhe descortina (ainda que não tenha plena consciência disto) o modo através do qual, em meio à coletividade, ele encontrará um relativo equilíbrio: deve trilhar o terreno instável (solo arenoso da praia) da vida, do qual recolherá apenas o suficiente para manter-se vivo dia a dia, sem possibilidade de acumulação. Neste sentido, o binômio Pátria/Religião, apresentado sob a fixidez rochosa de monumentos defecados por pássaros (ícones de liberdade), encerra o momento de uma ruptura definitiva do personagem com o universo da ortodoxia, pelo qual foi castigado e adoeceu. Tanto é que, após este momento na praia, seus pulmões saram e o tom da narrativa passa a ser mais leve. É interessante que nos detenhamos na forma como se dá o encontro do protagonista com a dupla Cristián/Filósofo:

Como Aniceto os observa enquanto andam de "acá para allá" y de "allá para acá" na praia, em dado momento percebe que também é avistado por ambos. Porém, o primeiro olhar que cada um deles lança sobre o jovem já exibe a diferenciação entre os mesmos. Cristián, quando olha, o faz como que para inspecionar a atitude de um inimigo em potencial: é um olhar lançado sobre a superfície, que ele chama de olhar de "gaviota salteadora", de um homem "de las alcantarillas, que sólo ve y siente la sangre". O filósofo alemão Martin Buber chamaria o incidente de encontro "eu-isso", no qual não há valorização da alteridade: "Era para él un simple reflejo luminoso, una sensación desprovista de cualquier significado subjetivo" (HL, pp. 195-196). Mais adiante o narrador, numa reflexão sobre os seres vivos que se alimentam do mar, descreverá a ave com a qual identifica Cristián: 
(...) y por fin la gaviota salteadora, reina de la costa y de la baía; terror de los patos liles y de los yecos, de las gaviotas y de los alcatraces, de los piqueros y de las cáhuiles, parásito que vive de lo que los demás consiguen con su trabajo personal. Míralo: persigue el piquero que ha cogido un trozo de jibia y lo picotea hasta que deja caer su pieza; la engulle y se prepara para un nuevo atraco ( $H L$, p. 233).

Já o olhar do Filósofo, segundo sua percepção, é carregado de subjetividade, posto que consegue enxergar a substância humana sob a descompostura da aparência física do adolescente esfarrapado. Como o jovem pintor se encontra desorientado, sem perspectiva para onde ir, começa a imitar os homens, a princípio sem nem ter noção do que procura. Ao encontrar um pedaço de metal (que não sabe se é bronze ou cobre, mas pensa ter algum valor comercial), o recolhe e, ao passar pelo homem que lhe havia sorrido, sem saber exatamente como agir, tenta dar-Ihe o objeto. Mas este, ao perceber que está com fome, devolve-lhe o objeto, respondendo que vale dinheiro, e que por isso deve continuar sua busca. Aniceto reúne outros pedaços de metal, até que se cansa, por causa do pulmão, e senta-se nos degraus de pedra à saída da praia, a observar os dois, que continuam sua atividade.

Ao fim da manhã, após examinar o que conseguiu, a dupla termina o trabalho e dirige-se à escadaria onde Aniceto se encontra. O narrador chama a atenção para a atmosfera do momento com o seguinte comentário: "Los miré acercarse y, a medida que se aproximaban, fui sintiendo la sensación de que entraban en mi vida y de que yo entraba en las suyas, ¿cómo?, no lo sabía; de cualquier modo; estaba solo, enfermo y hambriento y no podía elegir; fuera de ellos no había allí más que el mar, azul y frío" (HL, pp. 201-202). De fato, como ele havia de algum modo previsto, Alfonso o convida para que os acompanhe, vendam os metais e almocem juntos. O Filósofo conta que quando viu Cristián pela primeira vez, ele estava na mesma praia e na mesma posição de quando Aniceto os encontrou. Diz que passou vários dias recolhendo metal enquanto Cristián o observava, até que finalmente chegou perto dele e the disse que 0 mar joga um metal fácil de recolher na praia, pelo qual alguém paga. Salienta que não the ofereceu nem lhe perguntou nada, e o outro ainda demorou quase um dia para animar-se a recolher o primeiro pedaço de metal. As 
características de mentor exibidas por Alfonso podem ser observadas no trecho a seguir, quando ele comenta sobre seu propósito de cuidar de Cristián:

No sé hasta cuando estaré con él, pero me he hecho el propósito de no abandonarle; más aún, tengo el oculto designio de enseñarle a trabajar. En cuanto me sienta con ánimo suficiente, me iré con él: el trabajo empieza y el buen tiempo viene; el sur empieza a soplar con fuerza (HL, p. 252).

Enquanto o protagonista se mantém em atitude de isolar-se dos relacionamentos humanos - além do tempo passado no cárcere -, definha; porém ao encontrar novamente a liberdade e passar pela experiência de um viver comunitário, ao lado de Cristián e Echevarría, dá-se início a um processo de cura que envolve também os seus pulmões. $O$ conhecimento com 0 Filósofo e Cristián já começa com a mudança de atitude do protagonista. Nos relacionamentos anteriores, ele costumava ser um simples objeto da generosidade alheia. Este, diferentemente, inaugura-se pela partilha total do que consegue recolher na praia, junto com os dois.

Além de assumir a partilha financeira, após tantos contatos humanos dos quais apenas recolheu as experiências dos outros como elementos formadores de sua individualidade, o jovem pintor finalmente divide suas próprias experiências com os dois personagens citados. Após receberem o dinheiro dos metais, resulta emblemático o nome do restaurante humilde a que se dirigem para almoçar: El Porvenir.

A partir daí, do convívio e da troca de narrativas de vida entre os três homens, está dado no pequeno grupo o ideal comunitário do autor. Quando Aniceto acompanha Echevarría e Cristián, é possível relacionar a cena com o romance Wilhelm Meister de Goethe, quando o abade diz a William que "um jovem tem sempre motivo para juntar-se a alguém", expressando assim uma formação de caráter em meio à coletividade, o contrário de uma trajetória individual em busca de formação. No caso de Aniceto, observa-se que na falta dos pais, ele se aferra da figura de um mentor. Mas seu amigo, o dono das tartarugas, viajara sem ele. Somente no encontro com Alfonso, o Filósofo, é que essa lacuna irá se preencher. Em vista disso é que podemos sugerir que o Filósofo, em menor medida, cumpre um papel semelhante ao da Sociedade da 
Torre, em Os anos de aprendizado. No Wilhelm Meister, a Sociedade da Torre, composta por membros aristocráticos, observa e intervém, de modo deliberado, no processo de formação do protagonista. Georg Lukács, no posfácio do Wilhelm Meister (edição de 2009), explica que o objetivo da Sociedade é que "o sujeito apare as arestas, conforme-se com seu desejo e sua opinião às situações existentes e à racionalidade delas, insira-se no encadeamento do mundo e obtenha nele um ponto de vista apropriado" (p. 593)

Ao se traçar um paralelo de Hijo de Ladrón com os Anos de Aprendizado, notamos que, neste último, o papel de mentor assumido pela Sociedade da Torre tem a ver com uma orientação conscientemente dirigida, com o propósito de moldar Wilhelm e torná-lo um indivíduo adequadamente inserido na normatividade social da nobreza.

Apesar da relação aproximativa com o Bildungsroman alemão, Hijo de Ladrón não pode culminar em algo harmônico como sucede com o sujeito do gênero clássico, que aposta na unidade do ser. Na verdade, o sujeito sempre foi dividido, mas é a partir de Freud que se inicia o estudo sobre a descentralização do mesmo. Ao final das contas, a formação de Aniceto num mundo moderno não consiste, como discorre Lukács - em relação ao Wilhelm Meister -, em que ele "apare suas arestas, conforme-se com seu desejo e sua opinião e à racionalidade delas, insira-se no encadeamento do mundo e obtenha nele um ponto de vista apropriado" (LUKÁCS, 2009, p. 593). Na conjunção histórica do século $\mathrm{XX}$, já está plenamente estabelecido que 0 autoconhecimento é uma miragem, enquanto o autoengano é a norma. No mais, no livro convivem elementos de um realismo grotesco e por vezes, escatológico, ao lado de uma temática que o aproxima do Bildungsroman clássico, fazendo crer que Hijo de Ladrón pode se apresentar como exemplar que exibe a evolução do gênero Bildungsroman, ao refutar definições tradicionais como as de Morgenstern, Dilthey ou Jost.

Para Morgenstern:

[Tal forma de romance] poderá ser chamada de Bildungsroman, primeiramente e de preferência devido ao seu conteúdo, porque ela representa a formação do herói em seu início e trajetória até um grau determinado de perfectibilidade; em segundo lugar, também porque ela promove a formação do leitor através dessa 
representação, de uma maneira mais ampla do que qualquer outro tipo de romance(...) A tarefa de Os anos de Aprendizado de Wilhelm Meister não me parece ser outra senão a representação de um homem que se aperfeiçoa através da atuação conjunta de suas disposições interiores e das relações com o mundo exterior, de maneira gradativa e em conformidade com a natureza. A meta desse aperfeiçoamento é um equilíbrio perfeito, harmonia com liberdade. (MORGENSTERN, apud SELBMANN, 1988, pp. 64, 66)

Em Hijo de Ladrón, ao contrário dos mentores aristocráticos da Sociedade da Torre, os indivíduos que passam por Aniceto são pessoas humildes do povo, que têm por única vantagem sobre o protagonista uma maior experiência de vida, e é justamente essa experiência que Aniceto deseja apreender. O Filósofo, em sua experiência de miséria, expressa as posições ideológicas do próprio autor e nada impõe aos seus companheiros, pois apenas espera deles a partilha humana. Alfonso apresenta-se como um modelo de indulgência com a figura do Outro, o que faz vir à lembrança os escritos de Schopenhauer, segundo os quais, "o tratamento mais adequado entre dois homens não deveria ser 'Senhor, Sir, Monsieur, mas meu companheiro sofredor. Por estranho que pareça, estaria de acordo com os fatos, pondo o outro na luz adequada e nos lembrando do que é mais necessário: a tolerância, a paciência e o amor pelo próximo que todos precisam e, portanto, todos se devem" (SCHOPENHAUER, 2001, pp. 125-126). Manuel Rojas foi leitor de Schopenhauer, e as relações que se mostram coerentes com a doutrina deste filósofo procedem justamente dessas leituras.

Se o romance picaresco mostra a decomposição do sistema feudal espanhol e o Bildungsroman aponta para a descontinuidade da aristocracia latifundiária na Alemanha, talvez Hijo de Ladrón possa acenar para uma descontinuidade da ordem social chilena, tal qual se apresentava no começo do século $X X$, em direção a uma experiência mais libertadora, na qual a anarquia poderia ter seu lugar. Ernst Luwig Stahl é o crítico que desenha uma nova genealogia para o Bildungsroman, e mostra dois fatores como sua ascendência: os testemunhos de conversão religiosa dos pietistas - para os quais havia a crença de que a trajetória do homem é conduzida exclusivamente por Deus; e o romance de aventura, que teria sofrido exclusivamente na 
Alemanha um aprofundamento em direção ao Bildungsroman. Para Stahl, o momento fundamental para o aparecimento do Bildungsroman no século XVIII é aquele da transição do conceito religioso Bildung (formação) para o conceito humanístico-filosófico de Bildung, no século 18, que "só pode ser realmente compreendido a partir das circunstâncias preexistentes da história do espírito", já que o Bildungsroman seria "precisamente a expressão da transformação do conceito religioso de Bildung na ideia humanístico-filosófica de Bildung" (STAHL, 1988, p.120).

Talvez o caminhar do protagonista no romance de Rojas seja exemplo dessa transformação do conceito religioso para o filosófico-humanístico. O Chile da época ainda é um país em sua maioria católico, conservador (continua sendo-o até hoje). Do ponto de vista do autor, esse conservadorismo poderia dar lugar a ideais mais filosóficos e libertadores. Talvez seja esse o motivo pelo qual o personagem Cristián, homem tosco, tímido, ladrão e com problemas de vista, aluda - através de seu nome -, ao cristianismo católico chileno e represente um universo desordenado. Para ele, talvez a morte seja 0 desenvolvimento lógico de seu percurso, em termos da organização narrativa. A trajetória de Aniceto ao lado dele e do Filósofo pode ganhar contornos de alegoria, para a qual contribui sua chegada na praia, no dia em que conhece a ambos, além do destaque sobre as imagens das estátuas e das aves.

Aniceto Hevia, um caráter em evolução, caminharia, desta forma, junto com um cristianismo de aspecto decadente - que além de obscuro em suas motivações ("No llegué a saber, por aquellos días, lo que había dentro de Cristián y quizá no llegaría a saberlo nunca. Viviendo a su lado, en su contorno, sentí que lo rodeaba una atmósfera de una densidad impenetrable para la simple mirada o la simple cercanía") ( $H L$, p.246), possui o aspecto bestial da 'gaviota salteadora', como o define o Filósofo: "Es muy ignorante y no tiene más que dos temas sobre los cuales puede hablar unos minutos: la policía y el robo" (HL. p. 206).

Também é interessante notar a percepção que Aniceto tem em relação a esse personagem, reforçando que sua formação se encontra desvinculada da esfera religiosa: 
Sentía un poco de molestia hacia él y encontraba, ignoro por qué, que aquel nombre era muy poco apropiado para un individuo como él, rotoso y sucio. Yo no andaba mucho más intacto ni mucho más limpio, pero mi nombre era más modesto. Se me ocurría que para llamarse Cristián era necesario andar siempre bien vestido y no tener hambre (HL, p. 200).

Bem diferente da atitude de partilha de Alfonso, Cristián se isola na incomunicabilidade, que se apresenta como sinal de sua escolha em não conhecer-se, e consequentemente, perder-se como indivíduo. Ele é um ser que se isola, e que por isso se anula como individualidade. Personagem de um nome carregado de simbologia religiosa, é um ser que se dispersa e se lança na vida sem nenhum cunho reflexivo, e com isso, se mostra incapaz de coordená-la e dominá-la. Exatamente por isso, ele é incapaz "de dominar-se e de possuir-se". Essa atitude de Cristián diante da existência aproxima-se vivamente do conceito de pecado, não do ponto de vista religioso, mas do pecado ligado à tópica existencialista, segundo a qual ao banalizar e desperdiçar as possibilidades do homem, o pecado torna a vida dele anônima e insignificante, impede o constituir-se de sua personalidade, isola-o e oculta-o do ser e da existência (ABBAGNANO, 2005, pp. 32, 34).

Sabemos que o existencialismo emergiu como movimento no século $X X$, herdando alguns dos argumentos de filósofos anteriores, como Schopenhauer e Kierkegaard, ambos filósofos que tiveram importante participação na bagagem de leituras de Rojas. Segundo o filósofo e historiador da filosofia Nicola Abbagnano, "entende-se por existencialismo toda filosofia que se conceba e exercite como análise da existência, sempre que por 'existência' se entenda o modo de ser do homem no mundo (...)" (Ibidem, p. 40). O existencialismo nasce como uma reação frente às tradições filosóficas dominantes, tais como o racionalismo ou o empirismo, que buscam descobrir uma ordem legítima de princípios metafísicos dentro da estrutura do mundo observável, onde se possa obter o significado universal das coisas. Neste sentido, é coerente que Rojas, ao romper com o criollismo, em seu aspecto determinista, inclua em seus escritos ideias existencialistas. Rojas se vincula a este movimento por motivos tais como a imaginação social, a angústia existencial, a incomunicabilidade e a impessoalidade da sociedade 
contemporânea. Para Kierkegaard, o indivíduo só pode constituir-se como tal, através da reflexão, através da qual pode transcender a si mesmo, e desta forma passa a existir (KIERKEGAARD, 1979, p. 336). Ainda nesse sentido, Wilma Maas mostra que Lukács enuncia que se exteriorização é sinônimo de objetividade, significa que todo o mundo dos objetos, das coisas etc., nada mais é do que o espírito objetivado. Em outras palavras, "se conhecemos a verdade sobre as coisas e suas relações, conheceremos a nós mesmos na medida em que participamos do sujeito universal da evolução, do gênero humano, do Weltgeist (espírito do mundo). Neste sentido, a interiorização torna consciente o que era em si no processo total da história: o que era inconsciente torna-se aqui consciente e para si". (MAAS, 2000, pp. 211-212, apud Lukács)

Aniceto Hevia é produto do seu século e à semelhança da história de Oskar Matzerath em O Tambor, Hijo de Ladrón "se situaria assim, entre o tom biográfico de uma história de formação individual e a narrativa épica da história de um povo, de uma época" (MASS, 2000, p.233). Assim como acontece em Os anos de aprendizado, o romance de Rojas pode ser encarado como uma "obra na qual se representa o 'individual-universal', na qual os anseios individuais seguem paralelos às ambições de um grupo social"(Ibidem, p.216). Mas as ambições do grupo de Aniceto, marginal à sociedade, são bem mais modestas: reduzem-se a cama e comida quente.

Somente ao operar o reconhecimento de sua condição marginal é que Aniceto pode ver-se livre das arbitrárias sanções impostas pela sociedade e pela lei, e é assim que sua integração pessoal ocorre na medida em que aprende na subversão, a partir de sua não-integração na sociedade dominante, operando a quebra dos valores burgueses. De acordo com Lukács, "a crítica humanista à sociedade não se dirige somente contra a divisão capitalista do trabalho, mas também contra o estreitamento, contra a deformação do ser humano pelo aprisionamento no ser e na consciência de classe social" (LUKÁCS, 2009, p.585).

A sociedade da ordem, com a qual faz coro a Igreja Católica, impõe preceitos morais rígidos através dos quais somente pode considerar-se pertencente à pólis, aquele que se enquadra num esquema fixo. Seguindo as motivações ideológicas de Manuel Rojas, podemos observar que em meio a essa sociedade das primeiras décadas do século XX, o modelo capitalista 
aprisiona os seres na consciência de classe e condiciona-os à objetividade materialista até esvaziá-los de sua essência humana. Nesse sentido, as determinações fixas - definidas pela Igreja e a sociedade e ditadas pelo capital -, devem ser abaladas através da reelaboração das concepções do protagonista, e é por isso que sua caminhada ao lado de Cristián e Alfonso assume um importante valor simbólico.

Cristián possui um nome respeitável que remete no nome ao próprio Cristo, mas seus propósitos interiores são de usurpar o Outro, afinal é ladrão, e por isso não é liberto do aprisionamento ao materialismo pragmático do ser. É por isso que o Filósofo está mais próximo do ideal evolutivo humano, posto que, além de ter-se libertado, em parte, do trabalho escravo, não deseja usurpar o que é do Outro, numa postura egocêntrica - e portanto, dialógica com o sistema -, mas suas ações são de integração, exibindo, dessa forma, que detém a percepção de que encontra-se inserido numa totalidade.

Ao estabelecermos uma comparação do narrador de Hijo de Ladrón com o de Proust - que é outro dos autores recorrentes da biblioteca de Manuel Rojas, além de fonte explícita de inspiração literária - podemos observar que se o anonimato do narrador na Busca representa sua falta de comunhão com os seres, na obra de Rojas, o fato de nomear-se representa justamente 0 contrário: o desejo do protagonista pela comunhão, que se perfaz, de modo efetivo, no encontro com Cristián e o Filósofo. Nesta progressão, o último estágio em termos de relacionamento pelo qual deve passar o protagonista está em se voltar para si mesmo, ao escrever um monólogo que cumpre uma função analítica. Tal escrita ajuda a sistematizar o autoconhecimento e com ele, a formação da autoimagem, pois deixa de se constituir como mero "filho de ladrão": torna-se Aniceto Hevia, dono de suas próprias vivências e visão de mundo. Sobre essa temática, Phillipe Willemart, estudioso de Proust, diz que "a escuta de seu próprio discurso provoca no analisando associações auditivas que naturalmente o levam a um passado emocionante, falante e muitas vezes 'gozante'. É uma verdadeira anamnese auditiva (...) tanto quanto Swann que extrai um saber a partir de sua escuta, o analisando descobre aos poucos os signos que o marcaram" (WILLEMART, 2000, p. 81). 
“¿Cómo y por qué llegué hasta alli? Por los mismos motivos por los que he llegado a tantas partes. Es una historia larga y, lo que es peor, confusa. La culpa es mía: nunca he podido pensar como pudiera hacerlo un metro, línea tras línea, centímetro tras centímetro, hasta llegar a ciento o a mil; y mi memoria no es mucho mejor: salta de un hecho a otro y toma a veces los que aparecen primero, volviendo sobre sus pasos sólo cuando los otros, más perezosos o más densos, empiezan a surgir a su vez desde el fondo de la vida pasada."

Manuel Rojas 


\section{FOI HÁ MUITOS E MUITOS ANOS JÁ}

Já nesse parágrafo de abertura da obra apresentado na epígrafe acima, percebemos que a temporalidade no romance se dá pela não linearidade cronológica. O narrador em primeira pessoa começa em medias res, se referindo a uma certa prisão, enquanto parece que dirige seu relato a um interlocutor que já conhece a sua história de vida. Deste modo, o leitor toma conhecimento de que a história é longa e confusa, e já de início é advertido de que tudo o que passará a ouvir deve ser analisado cuidadosamente, pois além de ser uma narrativa autodiegética, o narrador não confia muito na própria memória, que "salta de un hecho a otro y toma a veces los que aparecen primero, volviendo sobre sus pasos sólo cuando los otros, más perezosos 0 más densos, empiezan a surgir a su vez desde el fondo de la vida pasada" (HL, p. 3). Dito isto, o narrador acrescenta que acha que em algum momento esteve preso, por algo de 'pouca importância', como um assalto a uma joalheria - com cúmplices. Todavia, até o presente da enunciação, afirma ignorar tanto a existência da joalheria, como os cúmplices que Ihe foram atribuídos. Como resultado da prisão e de muitas noites dormindo ao relento, contrai uma pneumonia. Ainda doente é libertado, magro e fraco. Divaga que nessa situação, uma saída teria sido morrer, já que nem trabalhar ele consegue por causa da fraqueza, que teria the causado uma queda de escada. Porém sobre que escada ele fala? Que tipo de ofício? Por outro lado, também conclui que "no es facil morir".

Em meio a esse discurso confuso, o leitor depara-se com inúmeras incógnitas a respeito do narrador-personagem que ao sair da cadeia, imagina caminhos possíveis como o trabalho ou a morte. O leitor fica sabendo que 0 narrador teria sido sentenciado por um roubo cujas circunstâncias também não se esclarecem.

O discurso indireto livre, empregado em larga medida, representa o mimetismo do caos dos pensamentos que vão sendo apresentados pela memória do narrador - em avanços e retrocessos, desestruturadores da 
unidade temporal - , tornando imprecisa a distinção entre 0 passado e 0 presente da enunciação, realizando, assim, a mimese do fluxo de consciência. Está claro que Manuel Rojas não é o primeiro a apresentar esse tipo de procedimento, que já havia atingido o ápice no Ulisses de James Joyce, de quem ele foi leitor. Pretendo, aqui, verificar os saltos e retrospectivas temporais presentes na estrutura da obra.

Em diversos momentos, o romance de Rojas aparenta que há um diálogo do narrador com um interlocutor; porém trata-se de um artifício, posto que na verdade, como já dissemos, o livro todo é um grande monólogo rememorante em que o leitor precisa se tornar parte ativa na organização textual (LíSIAS, 2008, p. 43). Ao se lembrar de um suposto acontecimento, Aniceto reproduz um diálogo entre ele e um determinado interlocutor. Através de uma pergunta ou observação formulada por esse interlocutor, o narrador conduz o leitor às respostas que se encontram em sua interioridade, por meio de uma retrospectiva de fatos anteriores ao presente do diálogo, que por sua vez já é um passado narrado por um personagem distanciado pelos anos. Muitas vezes, esse narrador introduz digressões sobre personagens preponderantes para a trama e conta o que aconteceu com esses personagens depois.

Como já vimos em outro momento, no Chile do começo do século $X X$ assistia-se ao desenvolvimento inicial de uma infraestrutura urbana e dos meios de transportes e ao aumento da demanda por serviços técnicos especializados. Esta situação gerou benefícios basicamente para as elites, em detrimento das camadas populares, provocando, assim, movimentos sociais que tentavam denunciar as más condições de vida dos obreiros bem como os profundos desequilíbrios sociais e econômicos.

No campo literário observamos a passagem do romance de forte cunho nativista e regionalista, resultante de um renovado nacionalismo literário, o criollismo - no qual a paisagem figurava como o princípio de convergência -, para uma crescente liberdade na estrutura do romance, através da qual o interesse nascente em torno da psiquê humana produz algumas inovações no tratamento do tempo e permite um pouco mais de flexibilidade na organização dos fatos. Lembremos que na Europa esse movimento começa com Proust e Joyce, e na América Latina com escritores tais como Teresa de la Parra, 
Eduardo Barrios, María Luisa Bombal, Eduardo Mallea. Neste contexto, a escrita aparece como representação de uma realidade dissolvida em múltiplos e multívocos reflexos da consciência.

Dado o caráter parcial e arbitrário do autoconhecimento em busca de uma evolução, o caminho para o mesmo não pode ser linear e descarteano: as recordações que reelaboram a vida de um indivíduo são soltas e alineares, e a forma de entrega disso no enredo é também descontínua. No romance em questão, mesmo os demais personagens são apresentados ao leitor como se fossem o próprio Aniceto Hevia, e isso porque num foro mais íntimo, como já vimos, a narrativa poderia ser encarada como um monólogo ou uma auto confidência. Esses fatores tornam apreensível o elo com a situação de uma sessão psicanalítica.

Assim como Riobaldo, de Grande Sertão: Veredas, que confessa "não ver em meio à travessia", nós também não enxergamos enquanto estamos imersos nos acontecimentos. Para o personagem Aniceto Hevia isso não se processa de forma diferente.

Em Hijo de Ladrón, tornam-se coerentes as várias lacunas de sentido tais como as circunstâncias da morte da mãe, Rosalía, o fim exato do pai de Aniceto, o porquê do aparecimento, em sua infância, de determinados indivíduos estranhos em sua casa ou mesmo a indeterminação de rumos na vida do herói.

A mãe é descrita pelo narrador como uma mulher de boa saúde, pois seus filhos nunca a veem sequer pôr batatas nas têmporas, como as outras senhoras. Uma noite, sem prévio aviso, o pai de Aniceto os acorda e chama um dos garotos para levarem-na ao hospital, e pela manhã recebem a notícia de que está morta. O comentário do narrador sobre o incidente é: "Aquella repentina enfermedad, más que asustarnos, nos sorprendió” (HL, p. 57). Após esse episódio, o pai é preso e vai parar em alguma prisão longínqua. Os filhos não sabem direito se é Sierra Chica ou Ushuaia: a informação mais consistente que eles recebem da justiça é que ele "fue condenado a una enorme cantidad de años de prisión, diez, quince, veinte - ya daba lo mismo (...)" (HL, pp. 6364). Podemos observar o fato do anonimato dessa prisão como uma marca histórica presente no livro, assim como a publicidade do delito que aparece quando vemos El Gallego estampado no jornal. A esse respeito, os 
historiadores Palma e Fernández explicam que, após "producido el ruidoso y público ingreso a la cárcel, tendía a sobrevenir el olvido y la indiferencia; la sociedad se desentendía de lo que ocurría al interior de los muros de detención y purga" (Palma \& Fernández, 2006, p. 275). Este anonimato no qual viviam os presos no Chile da época - dos quais El Gallego é um símbolo - parece estar ligado a uma existência degradante dentro dos muros dos presídios. Tanto é assim que "la experiencia de vida carcelaria era entendida por la sociedad chilena de fines del siglo XIX e inicios del XX como un lugar de castigo, como el purgatorio que en tierra debía vivir aquel que sin duda por sus crímenes pronto haría ingreso al verdadero infierno" (Ibidem, p. 284). Devido a isso, o índice de mortalidade era altíssimo entre os presidiários, índice esse ilustrado na narrativa com a morte do falsificador Nicolás e a provável morte de Aniceto Hevia.

Quanto aos 'amigos' do pai, os filhos não têm grandes informações a seu respeito, como diz o narrador no seguinte trecho:

Un amigo de tu papá... Esa frase lo decía todo y no decía nada; (...) ¿Cómo y cuándo los había conocido? ¿En dónde? ¿Qué tenía que ver con ellos? ¿Alguna vez habían viajado juntos, trabajado juntos, estado presos juntos? Quizá. (HL, pp. 186-187)

Este tipo de procedimento lacunar está ligado à tendência moderna em que personagens ou fragmentos de acontecimentos são articulados por vezes de modo tão frouxo que, com frequência, o leitor não consegue segurar qualquer fio condutor determinado (AUERBACH, 2009, pp. 491-496). Ao invés de representar com perfeição um decurso cronológico integral exterior, Rojas escolhe o recurso subjetivo das digressões e dos recortes, como é possível observar na advertência dada ao leitor já no começo do livro, no primeiro parágrafo citado há pouco, na epígrafe.

Rojas, seguindo a tendência dos escritores modernos, tais como Faulkner, Proust e Joyce não apresenta narrativas de um decurso exterior integral, dado o consenso estabelecido de fragmentação do indivíduo, que já não possui nenhuma pretensão de completude. Até mesmo com relação à aparência dos personagens e do próprio protagonista não há descrições 
completas, mas - quando as há - são apresentados apenas traços físicos, que não permitem ao leitor uma clara 'visualização'. O narrador não está em condições de impor à vida uma ordem que ela mesma não oferece, e é por meio dessa contradição que surge o que se poderia chamar de visão sintética do mundo (lbid., pp. 494, 495).

O narrador de Hijo de Ladrón não possui conhecimento seguro sobre aquilo que os seus personagens - por exemplo, o pai -, fazem, pensam ou sentem. Tudo o que ele sabe é o que eles the contaram (neste sentido assemelhando-se ao leitor) ou os eventos objetivos dos quais participa. Ao contrário de escritores como Goethe, Balzac ou Zola, que se posicionavam diante da realidade perfeitamente informados acerca dos caracteres de seus personagens, encontramos aqui impressões filtradas desde o ponto de vista do narrador, de muitos sujeitos que vão entrecortando as recordações do narrador-protagonista (Ibid., pp. 482, 483).

Por isso podemos relacionar as recordações do narrador ao papel da memória ligada à identidade e remontar ao enunciado platônico, segundo o qual porque lembramos e enquanto lembramos, somos. Jeanne Marie Gagnebin comenta que Adorno e Horkheimer estudam essa relação identidade/memória em Homero. Os filósofos tomam como exemplo a história do retorno de Ulisses a Ítaca, classificado como uma alegoria primeira da constituição do sujeito. No episódio dos Lotófagos, Ulisses, que deve retornar para os seus em Ítaca, tem que lutar contra a tentação do esquecimento.

A partir deste episódio, é possível estabelecer alguns paralelos e distinções do clássico grego em relação ao romance Hijo de Ladrón: a alegoria de constituição do sujeito se observa na ida de Aniceto ao Chile, país da mãe. Mas, ao contrário de Ulisses, Aniceto não tem para quem voltar, e a manutenção da lembrança, nele, funciona como eixo estruturante de sua estada e formação no mundo. Nesse sentido, pode-se observar o comentário do narrador, que diz que saiu ao mundo levando uma mãe morta, um pai ladrão e três irmãos desaparecidos. Apesar de ser um fardo pesado para um indivíduo tão jovem, sabe que pelo menos teve uma infância "casi feliz", com um lar e uma família: "otros niños traerían algo peor" (HL, p. 70), pois apesar de tudo, comenta que sua infância não foi desagradável e teve muitos acontecimentos apaixonantes. Como sua mãe era uma prodigiosa trabalhadora, sua casa 
ficava sempre limpa, e com isso, ele diz não haver encontrado a fome e a sujeira antes de ser entregue às próprias mãos, sem os pais. Apesar de ser filho de ladrão, "el ser más aborrecido de la sociedad, más aborrecido que el asesino, a quien sólo se teme", viveu com os irmãos uma existência aparentemente igual à dos filhos de famílias honradas que conheceu em colégios ou nas vizinhanças. (HL, p. 173), Além disso, acrescenta:

Tampoco estuve rodeado de gente sucia o grosera, borracha 0 de malas costumbres, y eso a pesar de que sentí respirar cerca de mí, pues estuvieron alguna vez en mi casa, uno y quizá dos asesinos. ( $H L$, p. 174)

A prática deste narrador rememorante parece se atrelar à ideia de que é necessário "reconhecer nossa condição de mortais, condição tão incontornável como a exigência implica: cuidar da memória dos mortos para os vivos hoje" (GAGNEBIN, 2006, p. 27). O narrador-protagonista, ao articular historicamente o passado, não o faz como se pudesse descrever um objeto físico e dar a conhecê-lo tal como foi, mas - parafraseando Benjamin - significa que ele se apodera das lembranças tal como elas cintilam, num instante de perigo, pois a história "é objeto de uma construção cujo lugar não é o tempo homogêneo e vazio, mas aquele preenchido pelo tempo-agora", posto que só o exercício da memória permite a reconstrução do próprio eu, pois a primeira pessoa passa a ser autoanálise (Ibid., p. 40). Nesse sentido é que Jean-Pierre Vernant, em relação ao canto poético da llíada, diz que "a palavra de rememoração e de louvor do poeta corresponde, em sua intenção e em seus efeitos à cerimônia de luto e de enterro" (Ibid., p. 45).

No início da narrativa, Aniceto Hevia confessa que não sabe como chegou no ponto em que se encontra, pois sua mente costuma saltar de um fato a outro, sem relacioná-los intimamente entre si. No entanto essa estrutura lacunar vai se modificando na medida em que passa a narrar sua trajetória, pois é a partir daí que percebemos o crescimento do personagem, que evolui "da dependência à autonomia, de uma certa inconsciência à consciência, indica a construção do sujeito-narrador que não depende mais absolutamente de uma existência anterior como na metempsicose, que não está mais atado a uma 
vida precedente e cuja nascença começa a se delinear" (WILLEMART, 2000, p.29).

O crítico literário Gilberto Pinheiro Passos comenta no prefácio do livro Proust, poeta e psicanalista, sobre a viagem no tempo, que "pressupõe modulações de sentido em torno das quais giram costumes e personagens, vistos, revistos e reinterpretados segundo uma ótica mutante e sempre conexa às novas impressões que se desvelam, com interesse crescente, tanto seres e suas motivações, como atmosferas rarefeitas e possibilidades de expressão romanesca" (PASSOS, 2000, pp. 13,14).

Estes aspectos ligados à viagem no tempo têm relação direta com a narrativa em primeira pessoa, posto que a memória que se tem das lembranças não corresponde diretamente à reconstituição objetiva dos fatos. 0 passado, sepultado na memória, pode se reapresentar inclusive como forma de lembranças encobridoras - para usarmos a caracterização freudiana - e deste modo se realiza a tentativa de proteger o indivíduo que rememora de uma dolorosa verdade esquecida.

Se este mecanismo ocorre com os indivíduos que possuem uma vida sem grandes sobressaltos e aflições, que se dirá de um personagem como Aniceto Hevia, que assiste, no começo da vida, ao desmoronamento da família? Mesmo durante a infância, quando supostamente existe a segurança do lar, o personagem, como filho de ladrão, confessa que jamais sua família se instalara num endereço a ponto de criar raízes. Além disso, existem os sobressaltos inerentes aos sumiços ocasionais do pai e da rotina de sentir-se desconfortável diante da sociedade.

Parafraseando Pinheiro Passos, podemos fazer referência à relação aberta que se estabelece entre o narrador de Hijo de Ladrón com o leitor que, a semelhança do narrador de Machado de Assis, em Dom Casmurro, sente que os juízos ficam em suspenso na narrativa e pode se perguntar: o que resta da família que se dissolveu e do menino que se viu abruptamente desamparado? "Resta a memória, que escava a crosta do tempo. Decorrente da expressão cambiante e paradoxal, sem o timbre obrigatoriamente determinante da realidade exterior, tão bem configurado pela literatura oitocentista, a percepção em mosaico possibilita o aleatório proporcionado pela memória involuntária". (PASSOS, 2000, p. 14) Como sabemos que o sujeito é um objeto construído, 
não há garantias, por parte do leitor, de que os personagens que estão nas lembranças do narrador são, de fato, devidamente representados.

O narrador, quando fala do menino Aniceto, se refere a vivências muito distantes do seu presente da enunciação:

Siempre me ha gustado el pan untado con mantequilla y espolvoreado de azúcar, y aquella tarde, al regresar del colegio, me dispuse a comer un trozo y a beber un vaso de leche. En ello estaba cuando sonaron en la puerta de calle tres fuertes golpes (HL, p. 12).

Mas quem é esse menino que comia pão com açúcar? É como se todo o conforto da infância inocente estivesse representado por este alimento justamente no momento em que a polícia bate violentamente em sua porta. Neste sentido, a fala da mãe ("- Bébete pronto esa leche") ${ }^{10}$ aponta para um conhecimento prévio da inevitabilidade daquele indesejável momento. 0 Aniceto de fases anteriores não é experimentado sempre de modo idêntico ao Aniceto narrador, mas de certa forma como personagem independente que é, desligado do Aniceto narrador, passa a ser uma das pessoas da narração, um personagem entre outros personagens. Desta maneira, o narrador de Hijo de Ladrón trabalha com dois "eus" que sustentam as lembranças: o de hoje que ainda vê o choro e as adversidades do menino e do jovem, e o do passado, desamparado em face do mundo. Para que se complete a sua formação como indivíduo é que o narrador precisa revisitar as experiências enterradas e guardadas por esse outro "eu", num processo de enunciação pela escrita. À semelhança de No Caminho de Swann, de Proust, "o romance seria apenas uma imensa condensação ou reunião no mesmo palco de acontecimentos que se entrelaçam no tempo." A partir deste episódio, se desfaz o tênue equilíbrio que sustentava toda a família: quando a força ordenadora da lei adentra as portas do lar e exige satisfação destes membros, que não têm relação direta com os crimes cometidos por Aniceto Hevia, então já não há refúgio possível. Nesse sentido, é como se Rosalía (que já estava acostumada a sair do

\footnotetext{
${ }^{10}$ Percebemos em Rojas a importância do símbolo do leite, ligado à segurança familiar. Exemplo disto é o episódio do basco, que lembra ao jovem desamparado os leiteiros de sua infância e o conto "El vaso de leche": neste conto, um jovem faminto é confortado por uma senhora de figura materna quando esta lhe dá dois copos de leite e dois pratinhos cheios de biscoito champanhe.
} 
ambiente doméstico para visitar o marido e resolver seus assuntos na prisão) já não representasse o seu papel de equilíbrio entre as esferas de fora e as domésticas.

Se usarmos a imagem da osmose, podemos observar que a mesma nada mais é que o movimento da água entre meios de concentração de diferentes solutos, separados por uma membrana semipermeável. Nela, a água se movimenta sempre do meio menos concentrado para o mais concentrado, com o objetivo de se atingir a mesma concentração em ambos os meios. De forma semelhante, é inevitável que as forças esmagadoras do sistema, em algum momento, adentrem aquela esfera familiar. Com isto, não é de se estranhar que Rosalía (para usar uma analogia com o surrealismo bretoniano) logo depois desta cena tenha se dissolvido sem explicações aparentes, tal como o peixe solúvel, cujo destino é dissolver-se na água.

Assim como o narrador de Proust, o de Hijo de Ladrón vê "na escritura um meio para que esqueça, afaste ou sublime aquilo que ressente ao dispersar-se na escritura e desempenha o papel de intérprete ou hermeneuta ao analisar os fatos vivenciados por seu protagonista" (WILLEMART, 2000, p. 40).

Quando o narrador fala do pai, percebemos em seu discurso um considerável teor de mágoa, como quando ele comenta das cotas de sofrimento pelas quais a família devia passar, como já vimos. Seu pai, com os aparecimentos e desaparecimentos repentinos, suas "hermosas barbas" e suas mãos brancas, também fascina o menino, que o imagina, quando não está em casa, como um ser que se desliza magicamente. Contudo, essa magia começa a se romper no dia em que a polícia bate à porta e leva mãe e filho. Além disto, o ladrão Aniceto Hevia pai é apresentado como um homem de vida instável que sonha em ver os filhos como "abogados, médicos, ingenieros o arquitectos" (HL, p. 61). Com isso, não os prepara para as contingências da vida: não Ihes ensina a roubar ("lo que también hubiera sido una solución"), tampouco a ganhar o pão de cada dia como trabalhadores simples. Para completar o quadro do sonho sem respaldo pragmático, Aniceto Hevia não registra nem documenta os filhos, posto que este ato seria incompatível com a discrição exigida por seu estilo de vida (isto mais tarde resultará na cena 
recordada pelo narrador, da tentativa de retorno à Argentina, e o veto, causado pela sua falta de cidadania).

A repulsa que o personagem sente pelos indivíduos miseráveis que não assumem a posição de andarilhos e estabelecem-se em pocilgas, adotando cachorros famintos e sujos pode vir, entre outros fatores, de sua origem não honrosa: um quadro que se apresenta como um espelho deformado de sua própria configuração familiar na sociedade, e por isso projeta nesses indivíduos os ressentimentos que suas censuras não the permitem sentir pela figura paterna. Podemos comprovar esse recalque no momento em que Aniceto se refere às "cotas de sofrimento" pela quais a família devia passar, quando comenta, por exemplo, que havia vivenciado maus momentos, mas pareceuIhe natural e lógico atravessá-los, pois talvez fossem uma contribuição que de tempos em tempos era necessário pagar a alguém que, embora desconhecido, seria exigente, e não era justo que apenas um, seu pai, pagasse sempre por todos. Lembra amargamente que quando ele e os três irmãos já estavam crescidos, ainda meninos, já deveriam responsabilizar-se por suas cotas, as quais, já que não podiam ser pagas em trabalho ou dinheiro, o seriam então em tudo o que eles, os filhos, tinham a oferecer no momento: "libertad y lágrimas" ( $H L$, p. 12).

Sabendo que a memória é uma construção política - e que não se trata de interpretar as lembranças, mas de construí-las -, se faz interessante remontar à cena do bêbado com as nádegas à mostra, cobertas de excrementos, tão vivamente recordada por Aniceto. Do ponto de vista psicanalítico, o sujeito somente o é desde a perspectiva do inconsciente, posto que há algo em nós que fala por nós. Diante daquela visão repugnante, é trazida à superfície e à vista do protagonista tudo aquilo que ele, à força, recalcara para si mesmo em relação ao seu âmbito familiar, sob o verniz de que seu pai fosse um homem sério, pacífico e trabalhador. Ao ver o bêbado exposto de modo bestial, ele sente a exposição em si mesmo, como se suas nádegas e suas coxas fossem dele, Aniceto. Não é à toa que essas barreiras de censura são furadas diante da visão de um bêbado dormindo, num duplo indício de revelação pela inconsciência: 
Me senté en la tarima, buscando un lugar desde el cual pudiera evitar la vista de aquel hombre, cuyo aspecto me llenaba de una terrible vergüenza, no porque hubiese impudicia en ello, sino porque había inconsciencia; el hecho de que no supiera ni pudiera saber el estado en que se encontraba, era lo que me producía aquella sensación; me parecía que, por mi parte, tenía alguna culpa en ello, no sé en qué, y seguramente no la tenía, pero no podía estar tranquilo(...) (HL, p. 105)

$\mathrm{Na}$ verdade, podemos aqui enunciar a respeito do encontro que 0 indivíduo tem consigo mesmo ao se deparar com algo que ele julga ser o objeto. Antes da visão do homem ébrio, tem-se a impressão de que Aniceto vive na ordem do Imaginário, na qual se depositam todas as ilusões que os indivíduos possuem acerca de si mesmos e dos outros: até ali, sua vida fora "como que escondida". A experiência de olhar o bêbado e inalar todo o mau cheiro o joga de chofre na ordem do Real. A partir daí é que se percebe uma tomada de consciência gradativa, que se dá no sentido da sua auto aceitação como ente marginal. Mas falta, ainda, assimilar pela ordem do Simbólico a elaboração de sua vida, ao narrá-la.

Apesar da mágoa demonstrada, existe uma relação de dualidade contraditória que emociona no filho em relação ao seu pai, e o leitor percebe a dificuldade do narrador, mesmo depois de tantos anos, em enxergar esse pai como um indivíduo nocivo para a sociedade:

...era mi padre y lo adoraba y quizá si, inconscientemente, lo adoraba más porque era ladrón, no porque su oficio me entusiasmara - al revés, porque a veces me dolía -, no que lo fuese, sino las consecuencias que el hecho solía producir. (HL, p. 172)

Naquela sociedade (como na nossa atual) quem escolhe o banditismo atrai para si o desprezo daqueles que vivem nos limites dos valores normativos. Palma e Hernandez comentam que no século XIX e começo do XX a publicidade do delito, que transformava o acusado em centro das atenções, foi intensa no Chile, e a imprensa, desejosa de 'retratar' o submundo do crime para o público, desenhava os infratores - física e psicologicamente - como monstros cruéis e sem piedade: 
La revelación pública de los criminales los estigmatizaba, los condenaba de antemano, haciendo del escarnio público de sus crímenes la sentencia que justificaba la vida infrahumana que se llevaba en las prisiones (PALMA \& FERNÁNDEZ, 2005, p. 278).

Com esta publicidade, o menino já sabia que em qualquer lugar que o rosto de seu pai fosse conhecido, poderia ser preso por um policial qualquer, "nada más que porque sabía quién era" (HL, p. 173). Talvez exatamente por conhecer as consequências sociais às quais o pai se expõe ao trilhar 0 caminho do banditismo é que o nosso herói, em nome do amor filial, o ama mais ainda por ser ladrão, como um mecanismo compensatório. Deste modo, repetidas vezes somos postos diante de um Aniceto Hevia / Gallego retratado como homem provedor da família, pacífico e sério. Para reforçar essa imagem a respeito do pai e conferir um aspecto respeitável a seu discurso, o narrador traz à memória o elogio que o técnico da polícia dirigiu a seu pai na ocasião em que foi levado preso junto com a mãe, quando este afirma que sabendo distinguir os tipos humanos, Aniceto Hevia é incapaz de fazer barbaridades e roubar porcarias. Ainda comenta que a polícia estaria mais tranquila se todos os ladrões fossem como o pai do garoto.

Além do técnico, o narrador também reproduz o diálogo entre o pai e a idosa, senhorio da casa, que como já vimos, mesmo ao descobrir sua 'profissão', pede-Ihe que fique, pois sabe que ele é um "hombre decente" (HL, p. 50). Esse narrador chega ao ponto de inverter os papéis sociais, quando, por ocasião do último roubo que desencadeou a ruptura total da família, pinta o cenário como se o pai tivesse sido uma vítima do destino naquela noite. $O$ crime que resultou em fracasso havia sido premeditado há muito tempo e a casa, alvo do ladrão, era para ele uma espécie de reserva bancária que apenas sacaria quando surgisse uma necessidade grande.

O narrador comenta que o pai, durante muitos anos soube quantas joias havia ali, como eram e onde se encontravam, como entrar e sair da casa e a distância entre os móveis. De vez em quando visitava a casa, provava as chaves e percebia que nada mudava. Conhecia daquele modo a residência porque já trabalhara como empregado ali, e enquanto o fazia, "estudió todo, sin 
robar nada" (HL, p. 259). Ele sabia que as joias não se moveriam dali, pois 0 dono da casa era um idoso de hábitos regulares. Deste modo é que, ao ver-se sozinho com os quatros filhos, Aniceto Hevia sabia que já não poderia ir preso e por isso resolveu "sacar sua reserva":

Fue. Pero el dueño murió también por esos días, tal vez el mismo en que murió mi madre, y los herederos estaban instalados en la casa. Mi padre forzó la puerta y entró. Uno de los herederos lo encontró cuando salía. En ocasiones, lo que el hombre cree que lo va a salvar, lo mata (HL, p. 258).

O detalhe sobre o último roubo do pai que não se explica bem nesta narrativa é que, se realmente Hevia é um personagem incapaz de cometer violências, deixa a incógnita do motivo pelo qual nesta ocasião ele é sentenciado a uma pena muito maior que a de costume. Lembremos que ele é conhecido justamente por assaltar joalherias à noite e à primeira vista, e portanto não teria porque esta sentença ter uma repercussão tão maior que as anteriores, - "una enorme cantidad de años de prisión ( $H L$, pp.64, 65), de onde no saldría sino muerto" ( $H L$, p. 213).

Jeanne Marie Gagnebin, ao comentar sobre Auschwitz, diz que os sobreviventes da tragédia não conseguiram esquecer-se nem que desejassem, pois é próprio da experiência traumática a impossibilidade do esquecimento e a insistência na repetição: "Assim, seu primeiro esforço consistia em tentar dizer o indizível, numa tentativa de elaboração simbólica do trauma que Ihes permitisse continuar a viver e, simultaneamente, numa atitude de testemunha de algo que não podia nem devia ser apagado da memória" (GAGNEBIN, 2006, p.99). Sem querermos estabelecer comparações entre o holocausto e a história deste delinquente hispano-americano, observemos apenas o aspecto psicológico da experiência traumática vivenciada pelo protagonista: é natural que ele não esqueça e, numa tentativa de resgate do passado, insista na repetição (como já mencionamos antes, em outro capítulo), seja ao manter-se em mudança de espaço físico, seja por não verbalizar detalhadamente seu passado, mesmo quando o narra. 
No capítulo "La herida" há um mecanismo que se aproxima da associação livre de ideias (lembremos que é uma longa digressão entre parêntesis, dirigida ao leitor). A ferida à qual se refere o narrador é física, pois se encontra no pulmão, e ele comenta sobre a necessidade de conviver com ela até que sare ou o conduza à morte. Todavia, esta ferida física nada mais é do que um índice de uma outra, original e impalpável, que o acompanhará por toda existência: o fato de ser filho de ladrão. Nesse sentido, observaremos como Cristián o auxiliará no processo de aceitação.

Enquanto Aniceto se fecha na absoluta incomunicabilidade, percebemos que se encontra ancorado no passado familiar, revivendo um tempo em que não podia identificar-se sem prejudicar o pai e toda a família. Exemplo disso, como já vimos, é quando ouve as histórias de vida de seu amigo, o vagabundo das tartarugas, mas se vê impossibilitado de contar-Ihe as próprias histórias, pois pensa: "¿Qué podía contar a mi amigo? Mi vida era como secreto, una vida para mí solo" ( $H L$, p. 55). Por isso, enquanto se fecha, suas vivencias estão mais próximas da melancolia do que da elaboração do luto. Em relação a isso, Gagnebin, citando Freud, comenta que na compleição melancólica o sentimento é "desvalorização, de empobrecimento, de esvaziamento: enquanto, no luto, é o mundo que se torna vazio devido à ausência da pessoa amada, na melancolia é o próprio eu que se esvazia, que não tem mais a força de se recompor, de viver novamente" (GAGNEBIN, 2006, p.105).

Aceitar a ferida ajuda Aniceto a sair do processo de repetição compulsiva da incomunicabilidade e é por isso que, entre outros motivos já abordados, o encontro com Cristián e o Filósofo se torna tão importante para o protagonista, pois é a partir daí que ele consegue enxergar no primeiro uma ancoragem no passado reforçada por sua falta de compreensão e esclarecimento também do presente. Isso faz com que deseje um destino diferente daquele reservado ao tímido e tosco ladrão. Somente a partir dessa aceitação, como já observamos, é que os pulmões do protagonista saram e o tom da narrativa passa a ser mais leve. Mas isso não quer dizer que contar a própria história para mantê-la na memória signifique contá-la sem capas, pois embutido na rememoração sabemos que se encontra o mecanismo do recalque, como pudemos observar na fala do narrador que ao contar a história do pai, o descreve praticamente como um indivíduo inofensivo. 
O mundo despedaça todas as pessoas e, posteriormente, muitos se tornam fortes nos lugares partidos.

Hemingway 
Neste ponto da análise, nossa constatação é de que Aniceto Hevia pode ser considerado um vagabundo em relação ao seu andar errante, porém não pode ser considerado um pícaro, pois não possui o elemento das artimanhas, muitas vezes ilícitas, utilizadas para a obtenção de vantagem nas diversas situações a que o gênero o enfrenta. Os acontecimentos da vida do jovem protagonista servem para desbastar sua ingenuidade e torná-lo apto a iniciar seu processo de formação e sua viagem, ao final, pode ser pensada como índice desse processo. Somada a todos esses fatores está a sua consciência de liberdade, através da qual sabe poder eleger entre o caminho da delinquência - no rastro do pai - ou o da pobreza, tornando-se assim agente de sua própria vida e do seu destino no que concerne às coisas que não lhe são fatídicas - como foram a morte da mãe ou a prisão do pai.

Aniceto vivencia acontecimentos que - como nos informa o narrador Ihe foram impostos, tais como cartas do destino que the vieram às mãos. Todavia, as decisões que ele tomará - explicitadas por meio de suas atitudes se apresentarão como suas respostas em meio aos sucessos vivenciados. Como a narrativa se inicia a partir da infância e primeira juventude de Aniceto (doze anos), se nos apresenta um período em que o mundo aparece em meio à névoa dos olhos juvenis do personagem. Quando lhe é imposto entrar de chofre, de forma adulta, no grande mundo, deve forçosamente passar a agir por conta própria, e essas ações correspondem a respostas que passará a dar diante da existência. Em seu livro sobre o existencialismo, o filósofo italiano Nicola Abbagnano argumenta que "por meio de cada uma dessas respostas, o mundo sai um pouco da névoa e toma certa forma diante dele" (ABBAGNANO, 2006, p. 18). A primeira resposta que Aniceto resolve dar é a escolha pelo caminho da pobreza, afastando-se assim, do destino escolhido pelo pai e do modelo do pícaro clássico. Seguindo a pauta de um outro grande existencialista, Jean Paul Sartre, poderíamos dizer que Aniceto escolhe a pobreza, e não a criminalidade - como seria de se esperar - porque ele não precisa buscar justificações para sentir-se 'determinado'. É ao tomar atitudes 
na vida que o protagonista passa a constituir-se como indivíduo, já que "o homem é senão o que ele se faz" (SARTRE, 1994, p. 11). Não obstante, ainda não possui uma noção clara, no início de sua 'peregrinação', de como gerir a vida em meio ao desamparo a que foi exposto. Em uma determinada passagem do livro História do Existencialismo, o filósofo Denis Huisman observa que do ponto de vista de Sartre, existir é ter consciência da existência, e esse processo de tornar-se consciente não começa simplesmente com a reflexão, mas esta permite à consciência intencionalizar-se (HUISMAN, 2001, p. 130). A reflexão em Aniceto ocorre, de modo mais amplo, à medida que ele conta sua história para um interlocutor imaginário - quando, na verdade, sua fala é dirigida a si mesmo. É através desse processo terapêutico da fala que observamos a chegada do personagem no marco intencional da consciência de que sua vida, como representante dos universos da ordem e da desordem, não pode simplesmente seguir de acordo com a normatividade social, mas à margem da mesma, sem que isto signifique, necessariamente, a delinquência.

O discurso deste narrador de cunho existencialista nos mostra Aniceto como um indivíduo livre, que se vê gradualmente propenso a responsabilizarse por seus atos. Por isso, nos parece que Hijo de Ladrón tem mais afinidade com o romance de formação que com a picaresca, de acordo com o conceito que vemos a seguir:

(...) ० Bildungsroman "representaria a trajetória de um indivíduo jovem bem-intencionado, ao final da qual se poderia reconhecer um efetivo aperfeiçoamento do protagonista, no sentido de que ele adquire o desejável equilíbrio entre sua conformação interior e o mundo exterior das relações sociais. No caso do pícaro, esse bom caráter, essa boa intenção estariam ausentes. (MAAS, 2000, pp. 72-73)

Mas é preciso fazer aqui também certas distinções em relação ao modelo alemão: não obstante a boa índole de Aniceto, que o aproxima em termos de caráter ao herói do romance de formação, o ideal de Aniceto não se encontra ligado à aristocracia, ele não projeta seus ideais em uma classe social superior à sua. Os anos de aprendizado representa uma visão política de mundo ligada aos ideais aristocráticos. Já em Hijo de Ladrón, o apelo político que se mostra é anárquico. Na verdade, Aniceto não parece ter uma ideia 
clara sobre onde deseja chegar: ele é simplesmente jovem, e como tal, aberto a possibilidades de aprendizagem que o grande mundo tem a the oferecer, como podemos perceber no seguinte trecho:

No tenía esperanzas, tenía necesidades - denme de comer, donde dormir y abrigo y quédense con las esperanzas -, pocas necesidades, pero urgentes y las personas que me rodeaban tenían las mismas y apenas si una que otra más: comer, no opíparamente; vestir, no elegantemente; dormir, no lujosamente, no, de cualquier modo, pero que no tenga hambre, que no tenga frío, que la gente no me mire porque mis zapatos están rotos, mi pelo largo, mis pantalones destrozados, mi barba crecida (HL, p. 214).

Confessa, outrossim, que ignora qual seja a imagem que fazem dele seus companheiros, e não possui a percepção de um indivíduo cujas possibilidades e disposições permanecem ainda desconhecidas, dada a sua juventude. Todavia, sente que há em si mesmo "un ímpetu o una inquietud que no tenía dirección ni destino, pero que me impediría aceptar para siempre sólo lo que la casualidad quisiera darme" (HL, p. 253).

Wilma Maas, em uma leitura do crítico alemão Wilhelm Vosskamp, afirma que as correlações entre a picaresca e o Bildungsroman, explicam-se primeiramente pelo alcance de seu programa narrativo. Além disso, "ambas as formas decorrem de um momento histórico em que o arranjo econômico que tinha no feudalismo e na aristocracia latifundiária sua sustentação sofre uma descontinuidade". Porém, especificamente o Bildungsroman é o produto das concepções ético-sociais de um grupo social determinado, não se restringindo somente a um conceito literário. Os anos de aprendizado de Wilhelm Meister foi escrito em um momento em que as aspirações da classe burguesa se orientavam em direção à aquisição de cultura pessoal e do exercício da educação como forma de aperfeiçoamento. Em um momento em que o indivíduo burguês tornava manifesto seu impulso de superação da estreiteza de ideais inerentes à sua origem social em direção à possibilidade de "formação universal", e o Bildungsroman surgiu como manifestação necessária dessa busca (MAAS , 2000, pp. 51, 112-113). 
Em Wilhelm Meister a vida longe das obrigações burguesas, sem acumulação de capital, o tornou "mais alto, mais forte e mais encorpado, mais distinto em sua natureza e mais agradável em seu comportamento" (GOETHE, 2009, p. 475), ao contrário de Werner, que ao viver para acumular fortuna "parecia haver antes recuado do que avançado", muito mais magro que antes, ombros caídos e com o rosto sem cor (p. 476).

Ao contrário do que é exibido em Os anos de aprendizado, em que Meister alcança uma ótima figura com a vida de errância , em Hijo de Ladrón a vida errante tem efeito lamentável sobre a aparência, posto que mostra o estilo de vida de indivíduos excluídos do sistema de acumulação de renda, como podemos observar na descrição que o narrador faz de Cristián e o Filósofo, quando os vê pela primeira vez:

(...) una chaqueta verdosa y lustrada, con el forro, y la entretela viéndose tanto por encima como por debajo, con unos bolsillos que más eran desgarraduras y unos pantalones con flecos y agujeros por todas partes, no podían dar indicios sobre sus sistemas de ganarse la vida. De una cosa, sin embargo, se podía estar seguro: sus rentas no llegarían a incomodarlos por lo copiosas. (HL, p.195)

Bem diferente é a descrição que o narrador faz do homem rico que aparece na prisão, que além de ter a aparência que vemos a seguir, ainda ostenta um relógio de ouro dentro da cela:

Era un hombre de treinta a cuarenta años, moreno, esbelto, todo rapado, muy menudo, vestido con un traje de color azul bien tenido; llevaba cuello, corbata y chaleco y su sombrero panamá no mostraba ni una sola mancha. (HL, p.147)

Em relação ao destino das personagens, Wilma Maas, apoiada em Schiller, comenta que Goethe soubera muito bem posicioná-las em relação ao todo, e é por isso que, no fim da narrativa, aparecem em uma posição bastante coerente com a apresentada no início da trama. Exemplo disso são os personagens Werner, Mignon, o arpista, Aurelie e Mariane, que recebem um destino definido e coerente com a lógica interna da narrativa (MAAS, 2000, p. 159). Ora, com exceção da mãe de Aniceto, que morre e é enterrada pela 
família, o destino das personagens em Hijo de Ladrón é incerto. O protagonista, por suas andanças, vai cortando relações com cada um dos personagens com os quais convive, desconhecendo, deste modo, seu paradeiro.

Ao final do livro, o protagonista só mantém relações com Cristián e o Filósofo, Alfonso Echevarría, com os quais conseguiu efetivamente dar curso ao seu processo de formação. Mesmo assim, quando conta ao leitor, distanciado pelos anos, não informa o fim exato destes personagens, e por isso todo o relato se apresenta como um estar a caminho, à semelhança do que ocorre com o destino dos demais. Neste sentido, mesmo quando a trajetória de Aniceto deixa a rota individual para a coletiva, o projeto de pintar casas ao final ainda permanece como 'futuridade'. Esta mesma 'futuridade' em termos de realização ocorre com Wilhelm Meister, posto que seu desenvolvimento individual conduzido pela Sociedade da Torre conflui em um projeto de sentido coletivo, planejado para o futuro e de caráter utópico (Ibidem, p. 174).

Ou seja, o livro de Rojas não se inscreve de forma perfeita no paradigma clássico alemão, já que ao se confrontar com as definições tradicionais, mostra elementos de uma evolução do gênero em outras direções, que têm muito a ver com o contexto hispano-americano, especificamente chileno em que 0 romance se desenvolve. Nesse sentido, podemos ilustrar esse paralelo ao observarmos a trajetória de Wilhelm Meister, que de acordo com Wilma Maas, adquire um novo estímulo após o encontro com a bela nobre Natalie (Ibidem, p. 139). Como o universo de convivência de Aniceto se dá entre "rotos" (maltrapilhos), a trajetória do protagonista recebe um novo estímulo após o encontro com Cristián e o Filósofo, através da comunhão já observada, que se dá entre os três, posto que o romance foi escrito em um momento em que as aspirações da esquerda socialista se voltavam para a esperança de sucesso da empreitada da União Soviética. Ao mesmo tempo, um numeroso grupo de tendências anarquistas tomava fôlego na América Latina. Aniceto Hevia, como o Wilhelm Meister, apresenta-se como figura emblemática de toda uma classe.

No Bildungsroman Clássico, em termos de historicidade, temos uma classe média que se movimenta em direção à emancipação política através de sua busca pelo auto aperfeiçoamento e a educação universal. Em Hijo de Ladrón temos a apresentação de uma classe marginalizada, possuidora de um 
comportamento político voltado para a liberdade, representativo da quebra de um sistema que opera no binômio opressores/oprimidos. Embora esse ideal se encontre no nível da utopia, como diria Mazzari, a utopia necessita de um fundamento histórico para revelar-se (MAZZARI, 1999, p. 73). 


\section{LISTA DE ILUSTRAÇÕES}

Imagem no 1 - Colégio Cardenal Cisneros - fundado em 1898, fechou as portas em 1998.

(Aniceto afirma haver estudado nesta escola, em Buenos Aires)

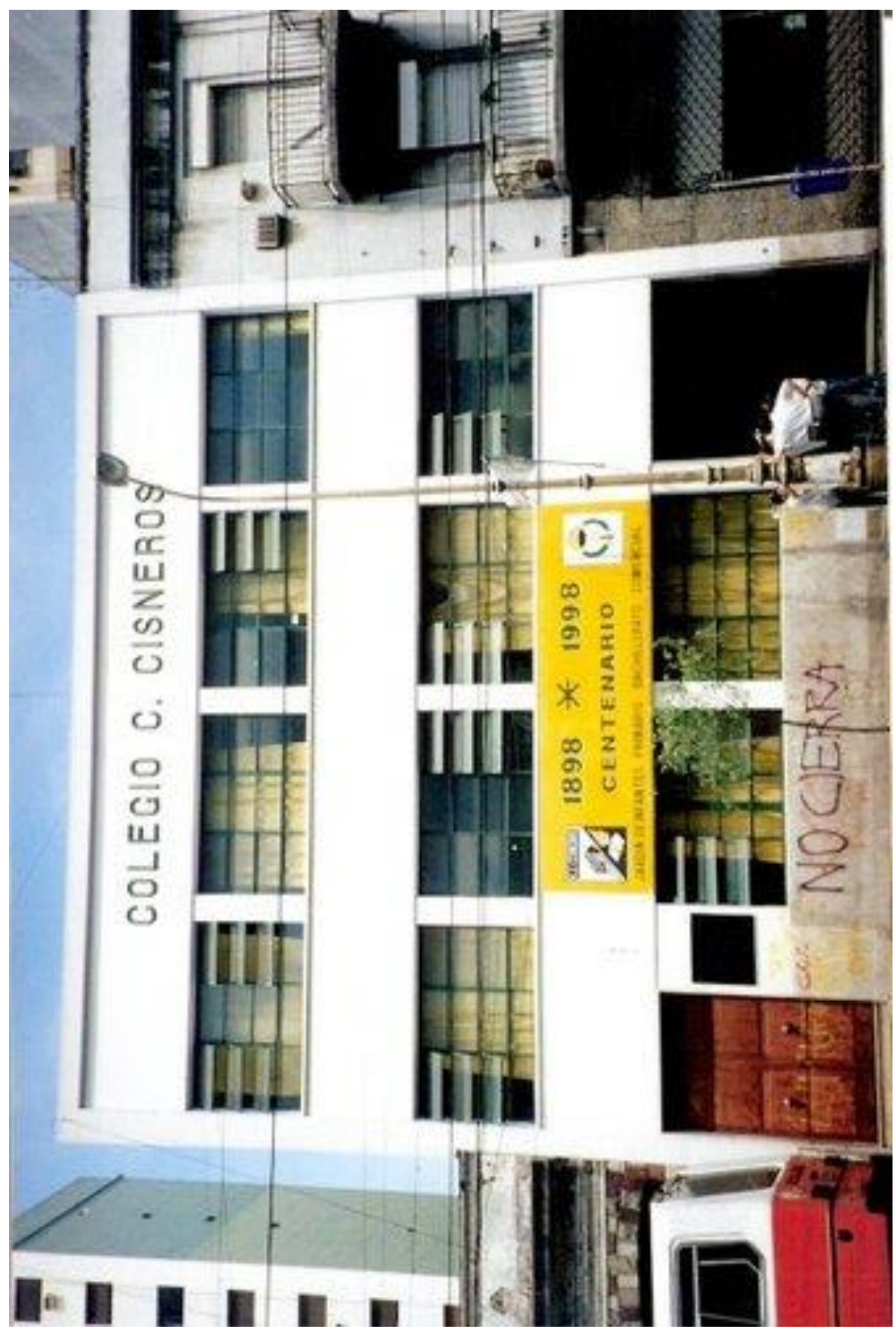




\section{Imagem nㅇ 2}

"Sierra Chica, una de las cárceles de máxima seguridad de argentina, situada a $16 \mathrm{~km}$. de la ciudad de olavarría." www.olavarria.com/.../laciudad/.../index.php

( Quando o pai de Aniceto é preso pela última vez, ele não sabe se o enviaram a esta prisão ou a Ushuaia)

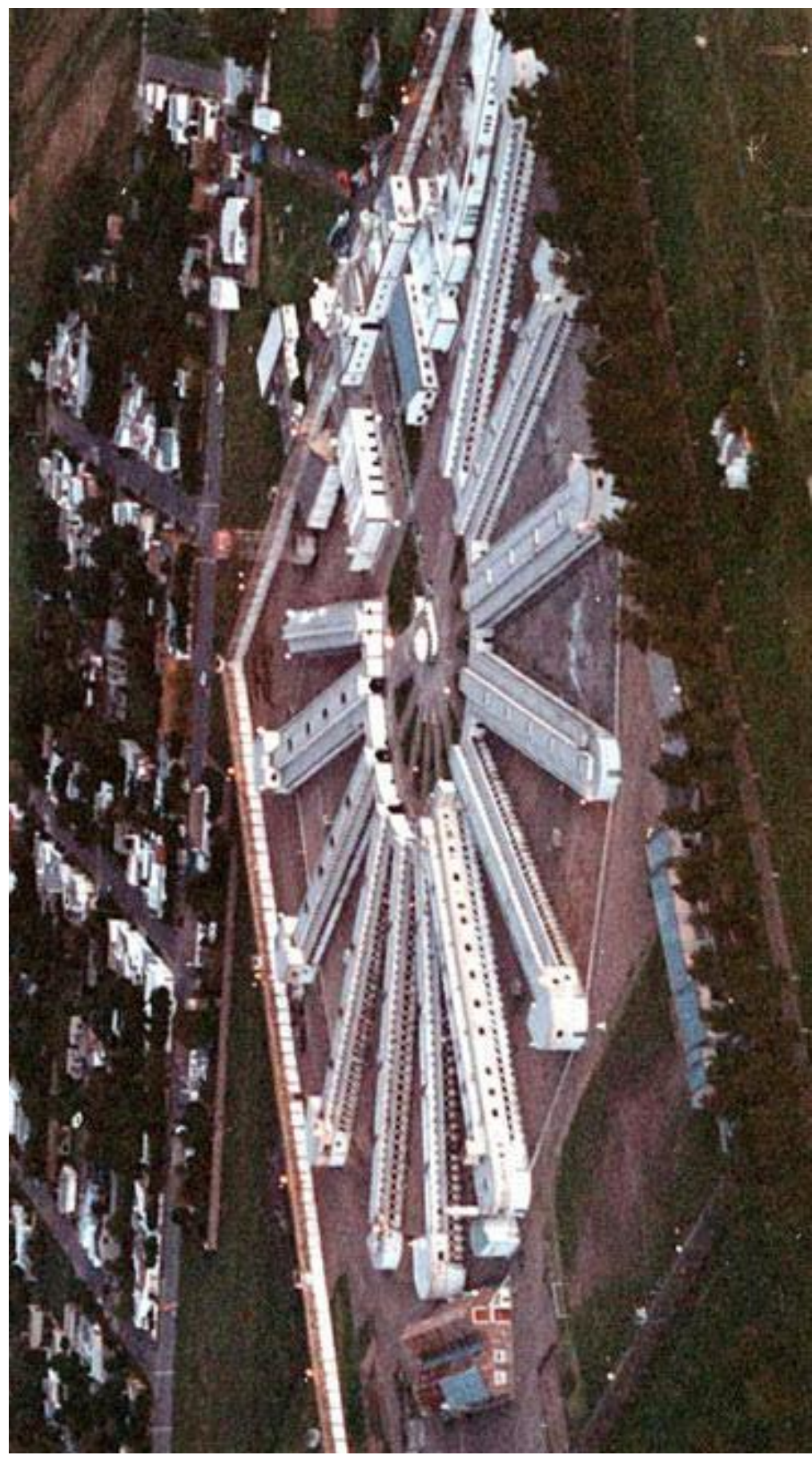




\section{Imagem no 3}

Penal de Ushuaia: "se empezó a construir en 1902 y en 1904 comenzó a recibir presos. Los presos llegaban tras un mes de viaje. Los recibían la desolación y el frío. Perón la cerró en 1947 por "razones humanitarias". http://edant.clarin.com/diario/2002/02/.../s-04615.htm

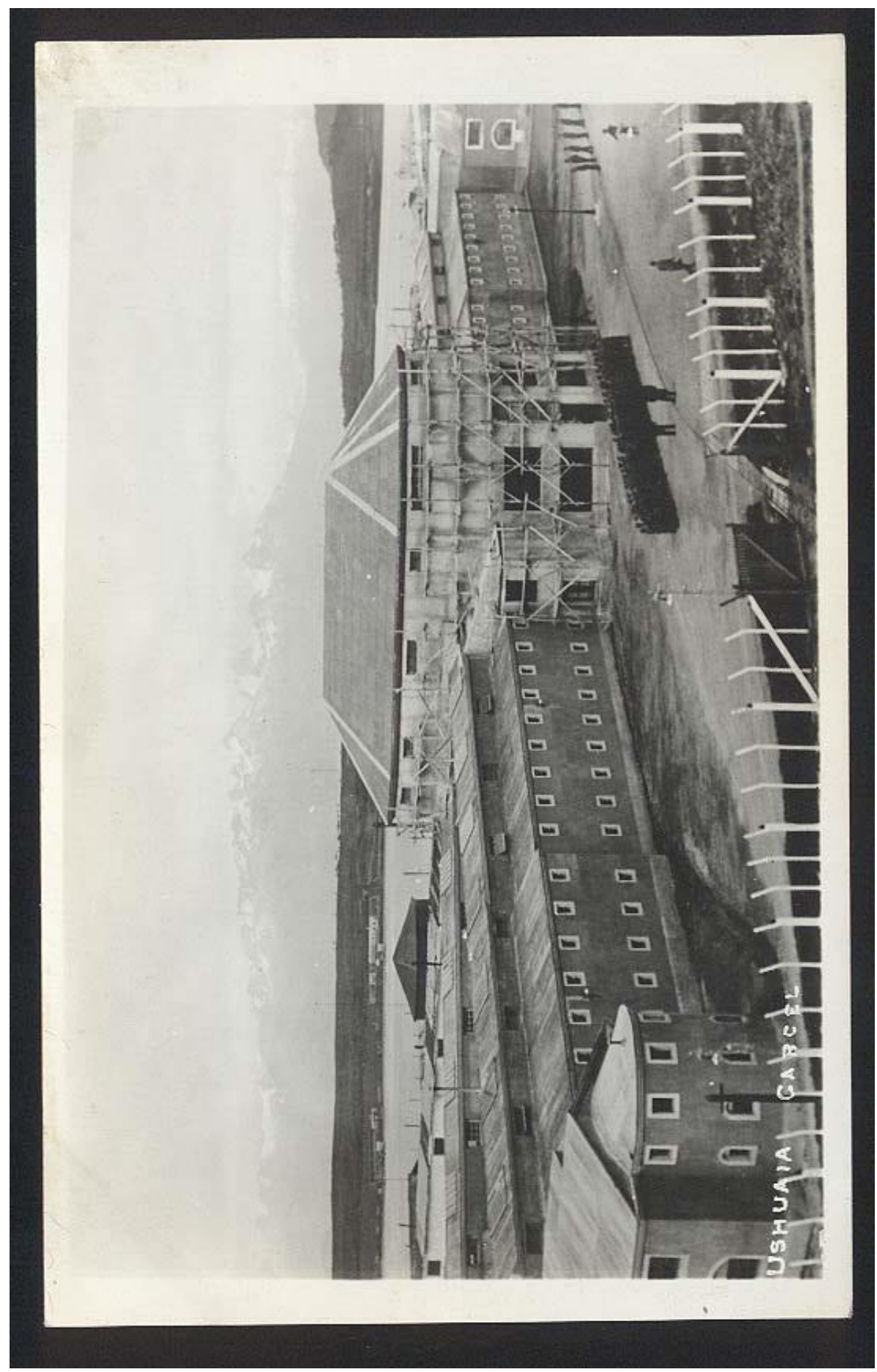




\section{Imagem no 4}

Durante la dictadura de Felix Uriburu (1930-1932), conscriptos de los regimiento 1, 2 y 3 de infantería fueron enviados a ushuaia para custodiar al grupo de presos políticos radicales. ...

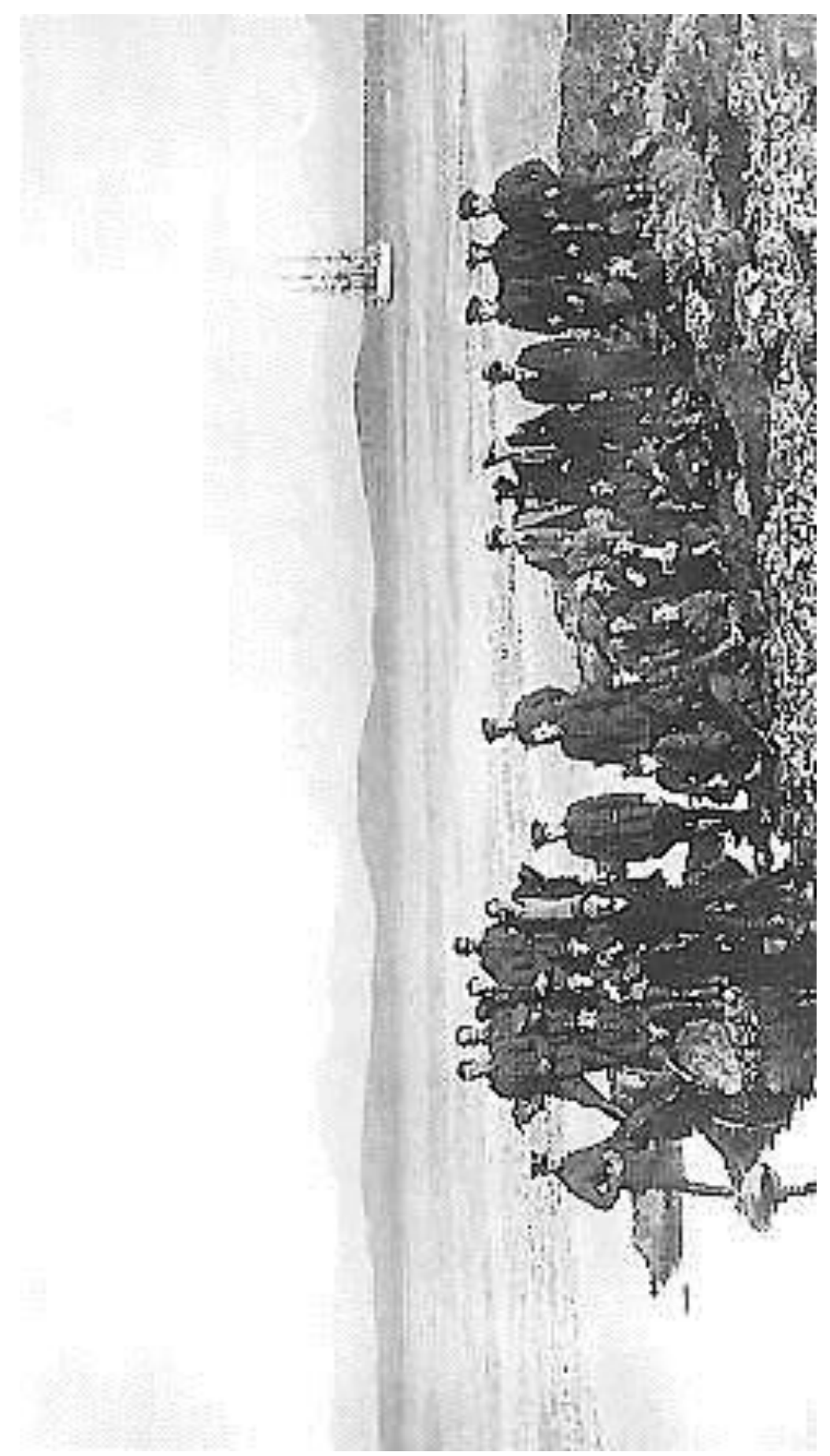




\section{Imagem no 5}

Presos con vigilancia permanente que hacía imposible la fuga. Los presos salían todos los días a trabajar, e en este caso están construyendo un puente: "pueden afirmarse que los reclusos tenían sólo tres formas de liberación de ese lugar: por cumplimiento de condena, por indulto 0 por fallecimiento." www.portalplanetasedna.com.ar/carcel ushuaia.h...

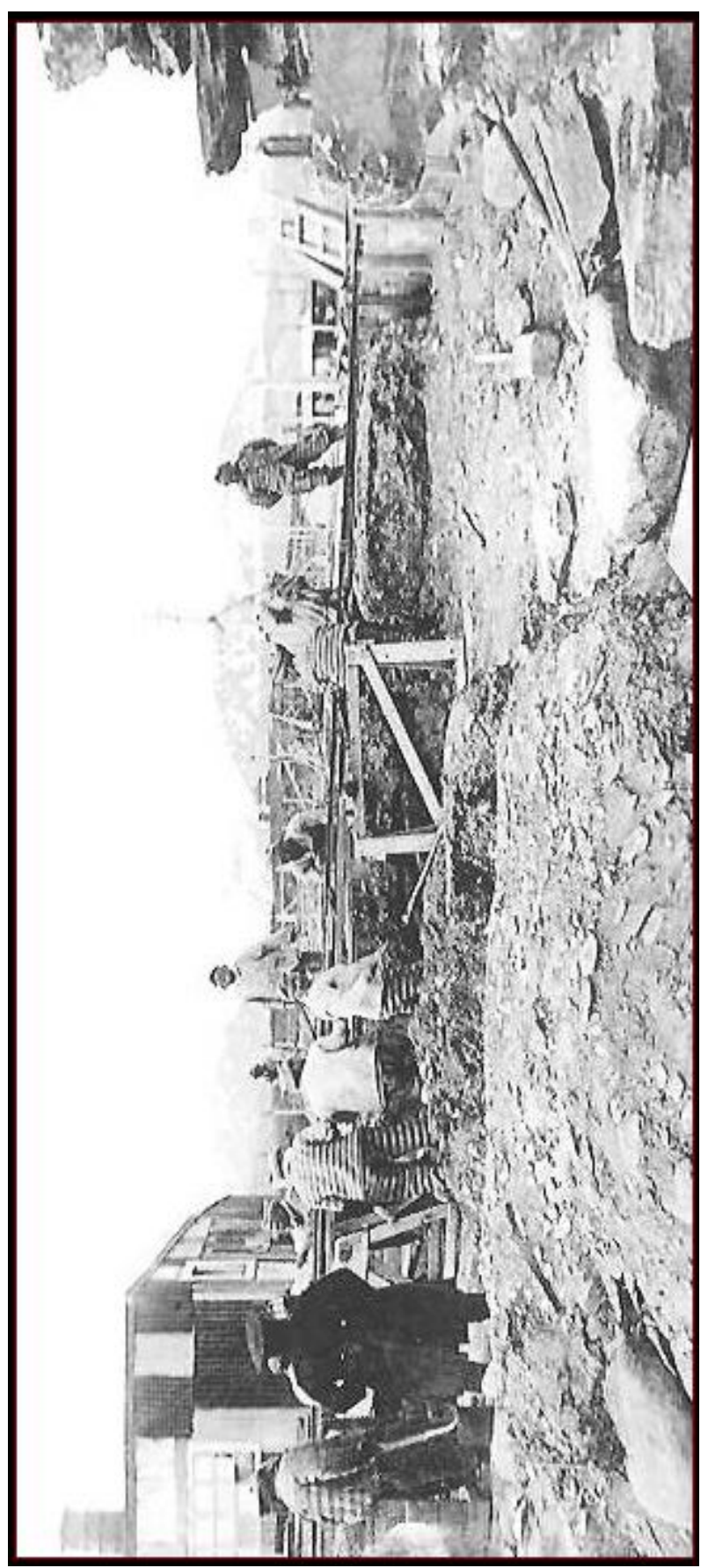




\section{Imagem no 6}

Conventillo $\mathrm{n} \cong 1$, construcción de dos pisos compuesta de cuartos redondos sin patio y con salida a la calle.

Fonte.: revista sucesos. ํ559, año XI. Valparaíso, 22 de mayo de 1913.

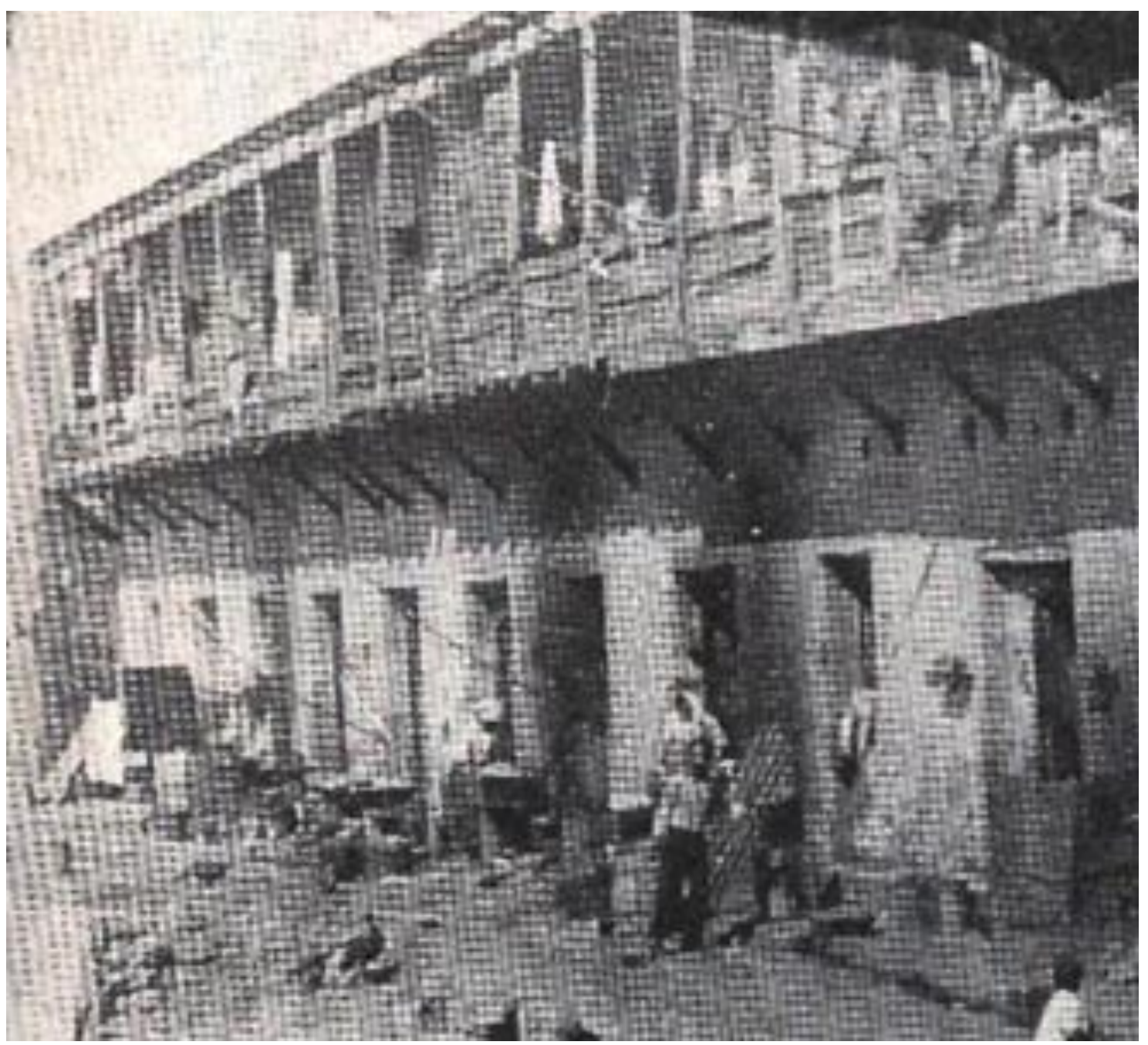




\section{Imagem $n=7$}

Conventillo $\mathrm{n}-2$, construcción de un piso con patio central. Es el conventillo "tradicional". Conventillo del tipo $\mathrm{n} \cong 1$, casa subdividida y adaptada. Fonte.: Olds Grant, Harry. Valparaíso, 1900. Fotografías. Edición de José Luis Granese Philipps. Santiago, Universidad Diego Portales, Fundación Andes, Sudamericana de Vapores, 1998. Reproducción con fines estrictamente culturales.

- El conventillo propiamente tal, es decir, el edificio de uno o dos pisos con cuartos que tenían su puerta hacia un patio común y central. Era la forma básica, pero había variaciones, o esquemas degradados como eran los materialmente más pobres (ver Fig. 3).

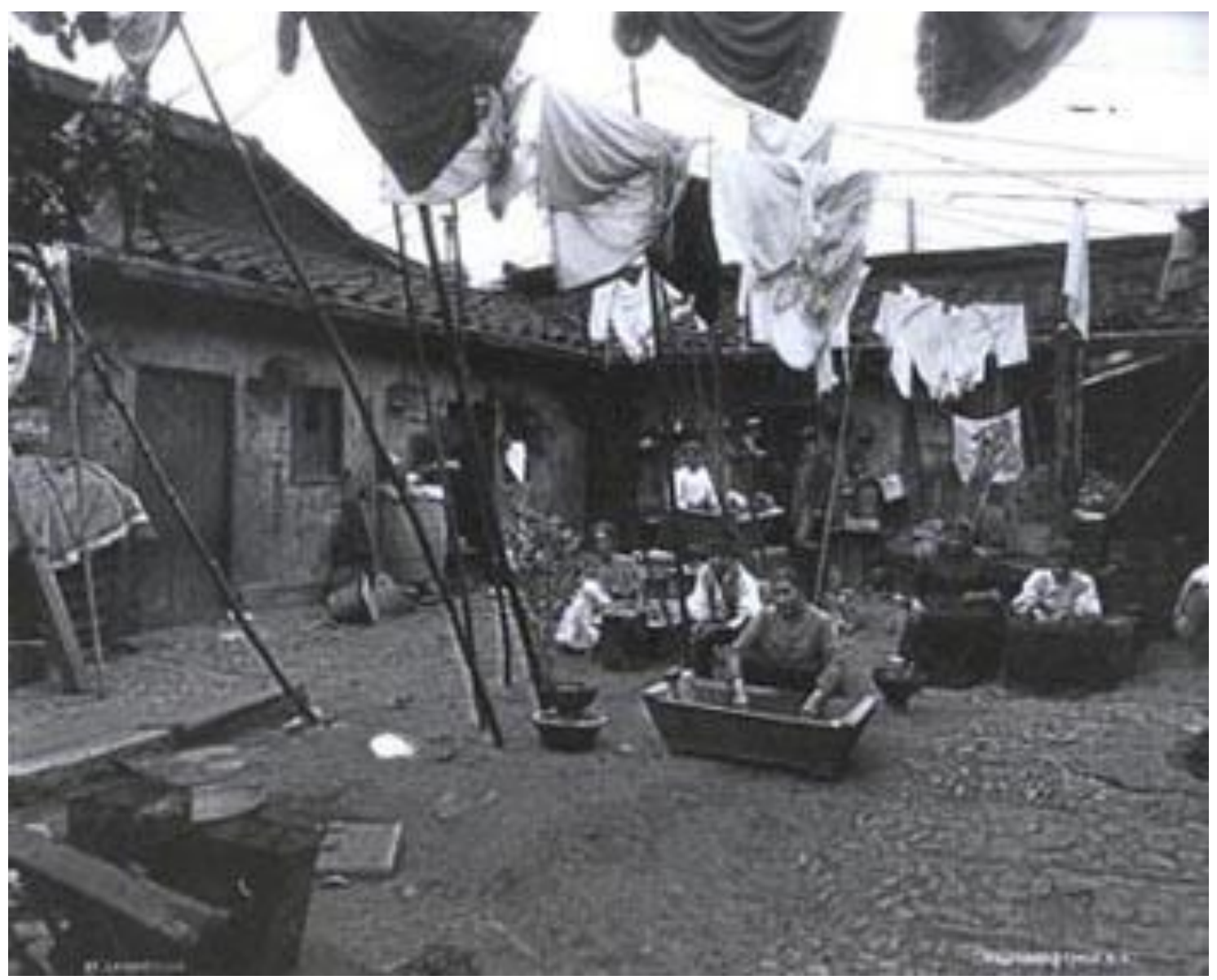


Imagem no 8

Conventillo no3. Fonte: Renzo Pecchenino Raggi (Lukas). Apuntes Porteños. Valparaíso, 1995. Reproducción con fines estrictamente culturales.

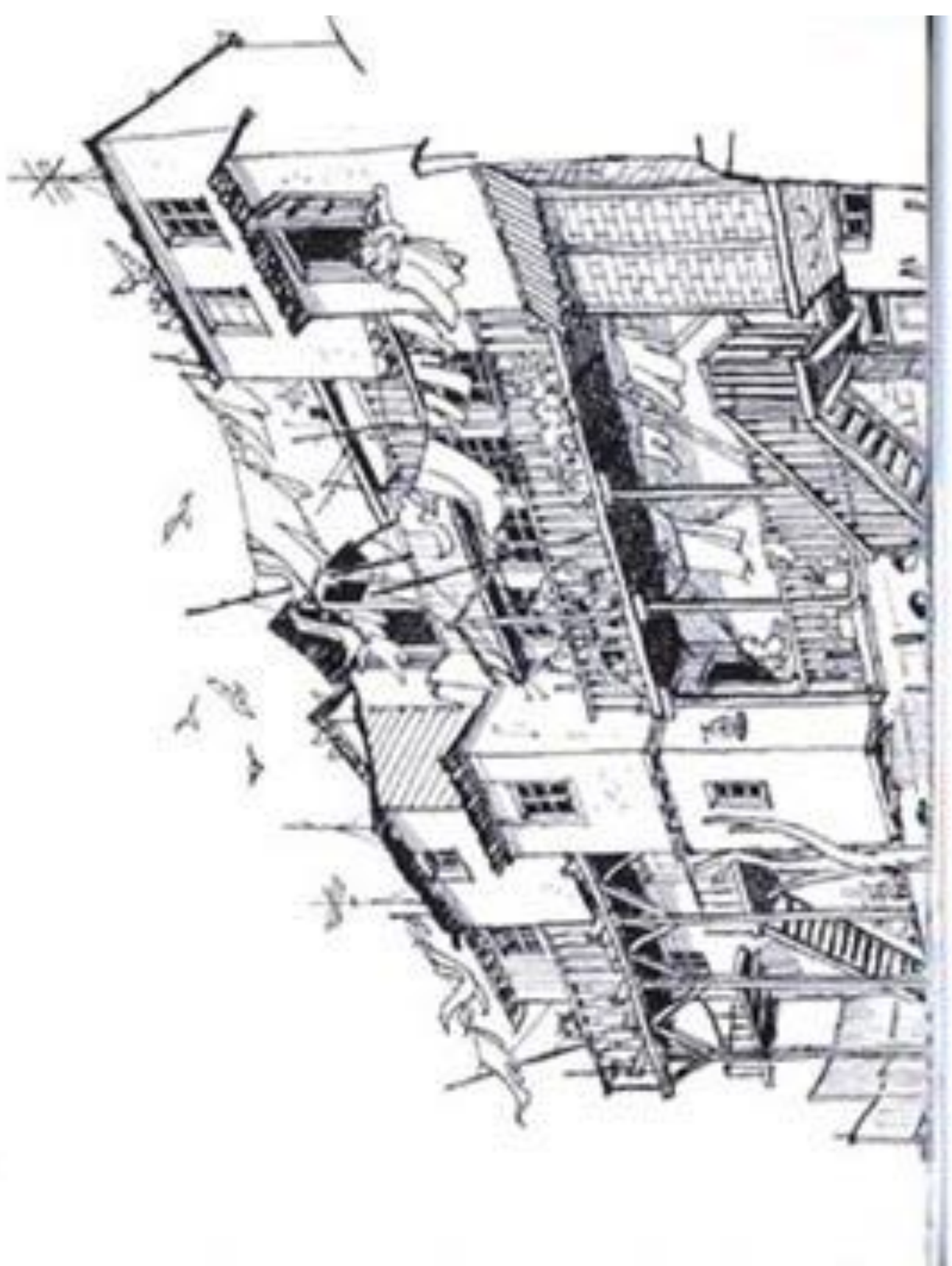




\section{Imagem $n \times 9$}

Pasaje Quillota anos 80. Foi nessa rua que Aniceto perambulou à noite, após o motim.

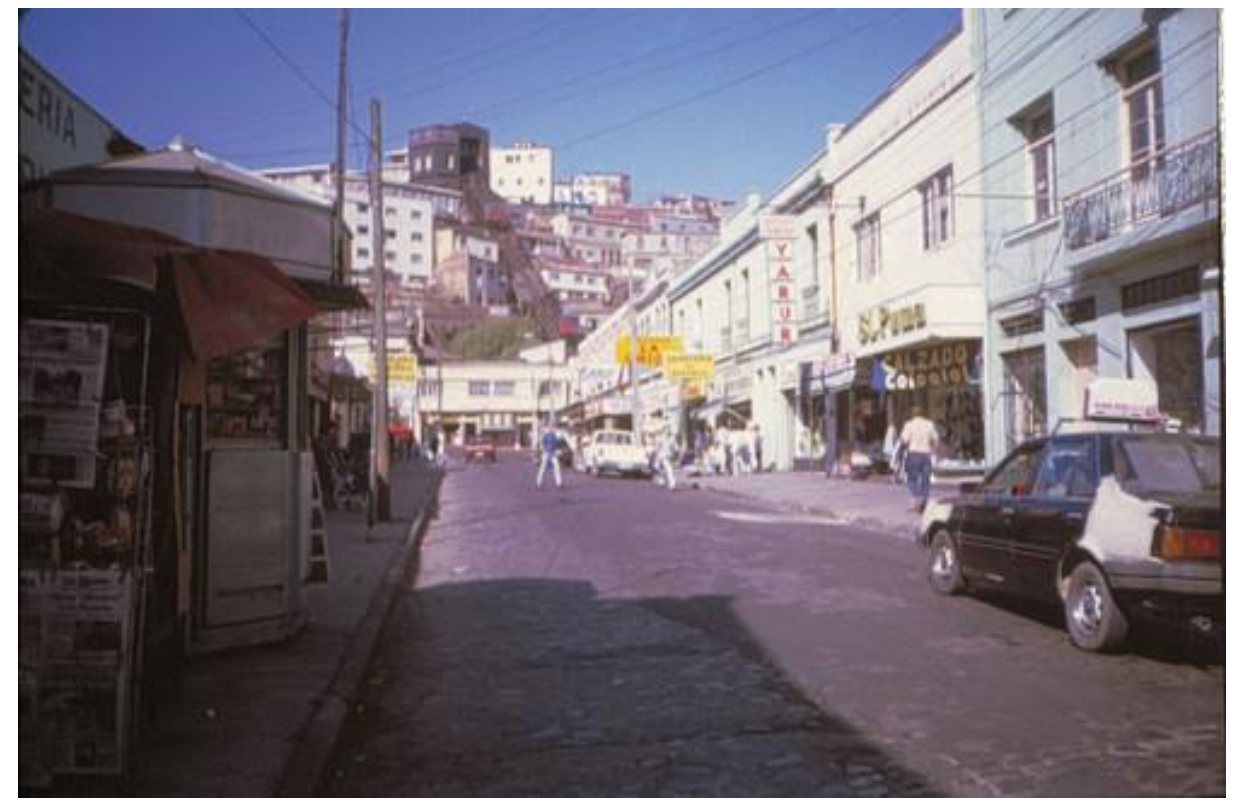

Pasaje Quillota início do século XX. Foi nessa rua que Aniceto perambulou à noite, após o motim. Lugar descrito como efervescente em bares e comércios. Os trabalhadores, ao final do dia, retornavam por aí para as suas casas, que ficavam na parte alta. Como a rua era comprida, poucos eram os que chegavam sóbrios em seus lares. Fonte: www.fotosepia.blogspot.com/

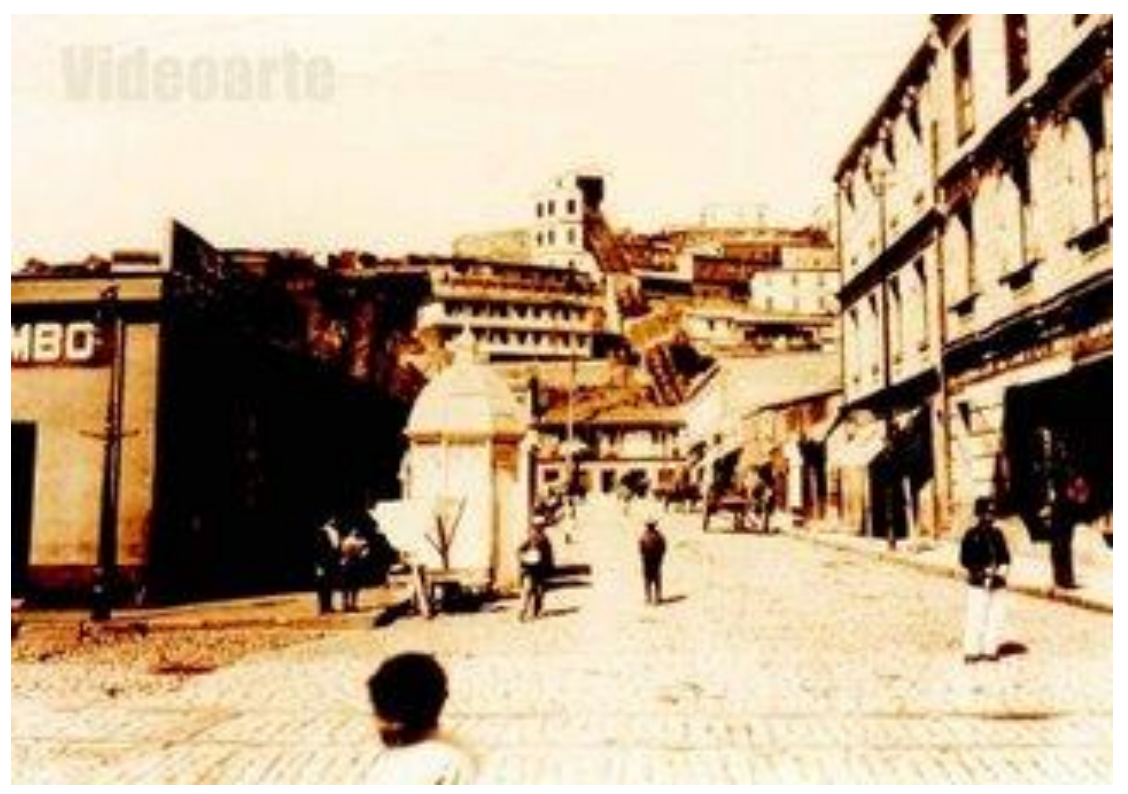


Imagem no 10

Calle Castillo 1890 - 1901

Esta es una muestra de como era calle Castillo entre los años 1890 - 1901

Seguramente el tranvía era toda una atracción. Actualmente calle tocornal Cerro

Barón. Fonte: www.fotosepia.blogspot.com/

(Aniceto faz menção a esta rua quando menciona o incidente dos ataques aos bondes)

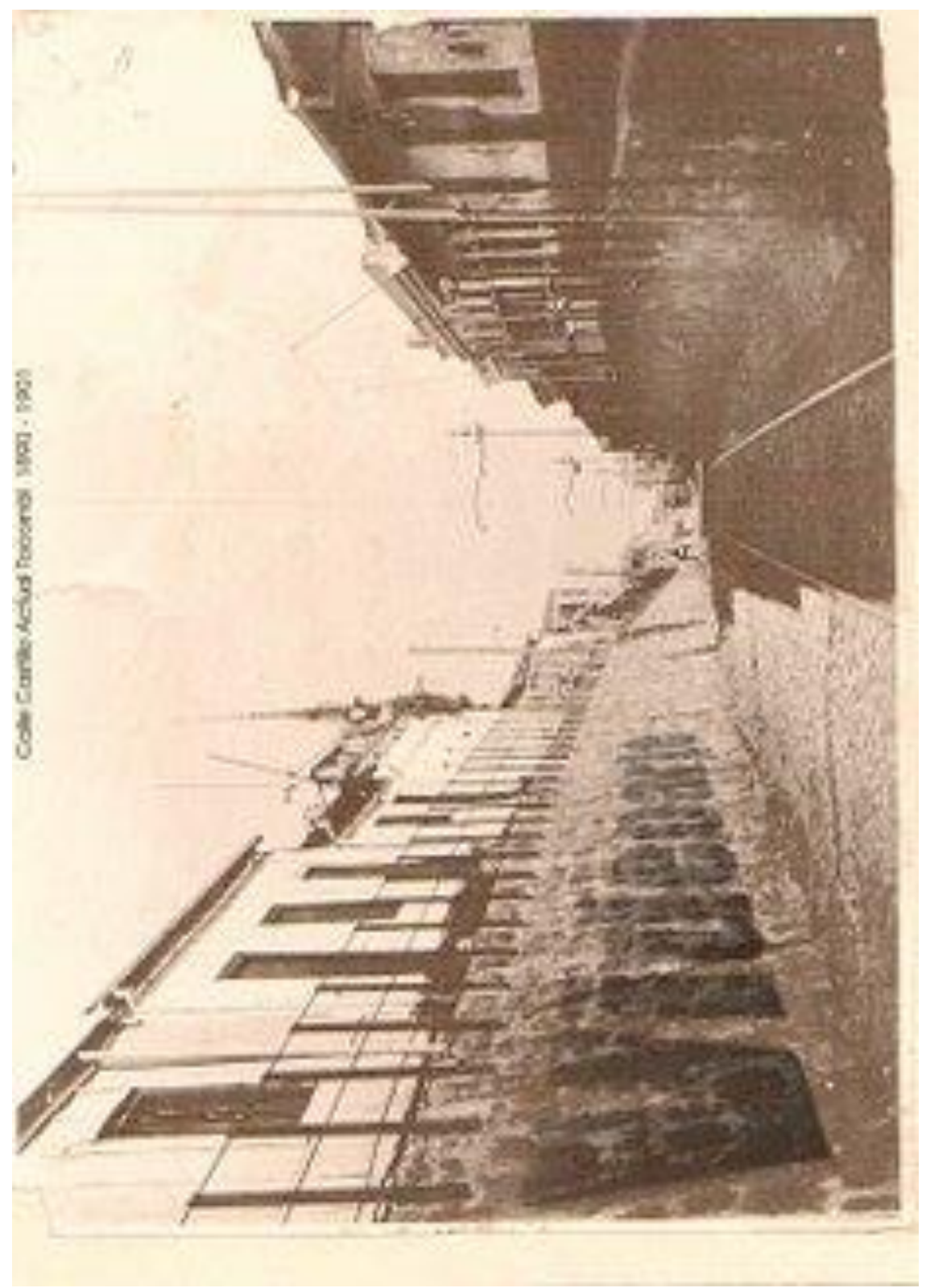




\section{Obras de Manuel Rojas}

ROJAS, Manuel. Hijo de Ladrón. Santiago de Chile: Zig-Zag, 1973.

setembro/outubro de 1940.

"Ensayo de la mañana". Revista Babel, ㄲo13, . "?Paz en Europa?". Revista Babel, №27, maio/junho de 1945. . "De que se nutre la esperanza". Revista Babel, n46, julho/agosto de 1948.

. De la poesía a la revolución. Editorial Ercilla, Santiago de Chile, 1938.

Antología Autobiográfica. Santiago de Chile: LOM Ediciones, 2008.

\section{Bibliografia sobre Manuel Rojas}

ARRIETA, Hernán Díaz. "La auténtica obra de arte se renueva desde sus entrañas", Disponível em www.memoriachilena.com.cl

AVARIA, Antonio. Entrevista con Manuel Rojas: "De Ganzúas y Ladrones", Disponível em estrellabolchevique.blogspot.com/2005_11_13_archive.html.

BAKER, Armand F., "Hacia una nueva novela: Estudio del tiempo en Hijo de ladrón, de Manuel Rojas." In: Disponível em http://www.armandfbaker.com/publications.html.

CORTÉS, Gloria Favi. "La representación memorable de la vida cotidiana en el cuento El delincuente de Manuel Rojas". Acta Literaria, ㄲ29, Universidad de Chile, 2004.

LATORRE, Luis Sánchez. "Homenajes a Manuel Rojas. (?)

LOPEZ MORALES, Berta. Hijo de Ladrón, novela de aprendizaje antiburguesa. Santiago: Editorial La Noria, 1987. 
MONTES, Hugo. "Fuerza y ternura en Manuel Rojas", em Artes y Letras de El Mercurio, domingo 3 de marzo de 1996.

NÓMEZ, Naín y Emmanuel Tornés Reyes. "Introducción" Manuel Rojas. Estudios Críticos. Santiago: Editorial Universidad de Santiago de Chile, noviembre de 2005.

PÉREZ, Florido. "Imágenes de infancia y adolescencia". Pluma y Pincel, №6, Santiago, junho de 1983. (Proyecto Patrimonio).

REYES, Emmanuel Tornés. "Prólogo" Manuel Rojas. Estudios Críticos. Universidad de Santiago de Chile, noviembre de 2005.

ROJO, Grinor. "La contraBILDUNGSROMAN de Manuel Rojas." In: Revista Chilena de Literatura - Sección Miscelánea, novembro de 2009.

SOTO,Román. "De Martín Rivas a Hijo de Ladrón: Transformación del mundo y aprendizaje subversivo", em Hispania, ISSN 0018-2133, Vol. 75, № 5,1992 , págs. 1139-1146.

TEITELBOIM, Volodia. "Manuel Rojas en la Feria del Libro de Buenos Aires 1985". Araucaria de Chile, no31 - 1985. (Proyecto Patrimonio).

VANWIEREN, Rachel. Búsqueda y mito en otra dimensión de la realidad: La Ciudad de los Césares de Manuel Rojas. Tesis para optar al grado de Magíster en Literatura Mención en Literatura Hispanoamericana y Chilena. Profesor patrocinante: Francisco Aguilera Gajardo. Santiago, Univ. de Chile 2005.

VIDAL, Virginia. “Cien años de Manuel Rojas”. Mensaje, ㄲo 34.

\section{Bibliografia crítica}

ABBAGNANO, Nicola. Introdução ao Existencialismo. São Paulo: Editora Martins Fontes, 2006.

ALEGRÍA, Fernando. "Introdución a los cuentos de Baldomero Lillo" in: Revista Iberoamericana, no 48, julho-dezembro de 1959.

AUERBACH, Erich. "A meia marrom". In Mimesis. São Paulo: Editora Perspectiva, 2009.

ARANGO L., Manuel Antonio. Origem y Evolución de la Novela Hispanoamericana. Bogotá: Tercer Mundo Editores, 1989.

BRETON, André. Nadja. São Paulo: Cosacnaify, 2007. 
"Manifesto do Surrealismo". In Manifestos do surrealismo.

Rio de Janeiro, Nau Editora, 2001.

BRAIT, Beth. "As vozes bakhtininianas e o diálogo inconcluso". In Dialogismo, Polifonia, Intertextualidade. Barros, D L P; Fiorin, J L, Orgs. São Paulo: Edusp, 2003.

BUBER, Martin. Eu e Tu. 10 ed. São Paulo: Centauro, 2006.

BENJAMIN, Walter. Ensaios Reunidos: Escritos sobre Goethe. São Paulo: Editora 34, 2009.

CALDERÓN, Demetrio Estébanez. Diccionario de términos literários. Madri: Alianza Editorial, 2006.

CANDIDO, Antonio. "Dialética da Malandragem (caracterização das Memórias de um sargento de milícias)" in: Revista do Instituto de estudos brasileiros, ㄲo 8 , São Paulo, USP, 1970, pp. 67-89.

ficção. São Paulo, Perspectiva 2011.

. "A personagem do romance". In A personagem de

CARPEAUX, Otto Maria. Introdução: "O Reino dos Karamázov", in Os irmãos Karamázov. São Paulo: Editora Ediouro, 2001.

COLOMBO, Eduardo. Anarquismo, educação social e dever de obediência. São Paulo: Editora Imaginário, 2003.

COUTINHO JORGE, Marco Antonio. Fundamentos da psicanálise de Freud a Lacan - As bases conceituais. Rio de Janeiro: Zahar, 2000.

DONOSO, Ricardo. Breve historia de Chile. Buenos Aires: Eudeba. 1963.

DUPUIS, Jules- François. Historia desenvolta do surrealismo. Lisboa: Antígona. 1979.

ESPINOZA, Vicente. Para una historia de los pobres de la ciudad. Santiago de Chile: Ediciones Sur - Colección Estudios Históricos. 1988.

GAGNEBIN, Jeanne Marie. Lembrar, escrever, esquecer. São Paulo: Editora 34, 2006

Posfácio: "Entre sonho e vigília: quem sou eu?", texto de 2004, in Em busca do tempo perdido - no caminho de swann. Editora Globo, São Paulo, 2006.

GALDAMES, Osvaldo Silva. Breve Historia Contemporánea de Chile. México: Fondo de Cultura Económica México. 1999 
GOETHE, Johann Wolfgang Von. Os anos de aprendizado de Wilhelm Meister; apresentação de Marcus Vinicius Mazzari; posfácio de Georg Lukács(1936) São Paulo: Editora 34, 2009.

GOIC, Cedomil. La novela hispanoamericana. Santiago: Ediciones Universitarias de Valparaíso, 1973, (pp. 38,39).

GONZALEZ, Mário M. A saga do anti-herói. São Paulo: Nova Alexandria, 1994. . O romance picaresco. São Paulo: Ática, 1994.

HAMBURGER, Käte. A lógica da criação literária. São Paulo: Editora Perspectiva. 1986.

HUISMAN, Denis. História do Existencialismo. Baurú: EDUSC. SP, 2001.

IMBERT, Anderson. Historia de la literatura hispanoamericana - II. México: Fondo de Cultura Econômica, 2005, (pp. 116, 117).

JACOBS, J. Krause, M. Der Deutsche Bildungsroman - Gattungs-geschichte von 18. Bis zum 18 Jahrhundert. München: C.H. Beck, 1989.

KIERKEGAARD, Søren Aabye. Diário de um sedutor ; Temor e tremor ; O desespero humano - Coleção Os Pensadores. São Paulo, Abril Cultural, 1979.

LACAN, Jacques. O Seminário, livro 2: o eu na teoria e na técnica da psicanálise. Rio de Janeiro, 3a ed. Jorge Zahar ed., 1992.

LATORRE, Mariano. Autobiografía de una vocación; Algunas preguntas que no me han hecho sobre el criollismo. Santiago: Universitaria, 1953.

LIHN, Enrique. "Prólogo da antología Diez cuentos de bandidos", Santiago: Editorial Quimantu, 1972.

LÍSIAS, Ricardo, "Um guia de Ulisses de James Joyce." In: Revista Entre Livros, no 9, São Paulo: Duetto Editorial, 2008, p. 43.

LUKÁCS, Georg. "Posfácio Os anos de aprendizado de Wilhelm Meister", texto de 1936, in Os anos de aprendizado de Wilhelm Meister. São Paulo: Editora 34, 2009.

MARTINS, Joel \& Bicudo, Maria Ap. Viggiani. Estudos sobre Existencialismo, Fenomenologia e Educação. São Paulo: Centauro, 2006, 2ªed.

MAAS, Wilma Patrícia. O cânone mínimo: o Bildungsroman na história da literatura. São Paulo: Editora UNESP, 2000.

MAZZARI, Marcus Vinicius. Romance de formação em Perspectiva Histórica. São Paulo: Ateliê Editorial, 1999. 
MORGENSTERN, K. Über das Wesen des Bildungsromans (1820). In: SELBMANN, R. (Ed.) Zur Geschichte des deutschen Bidungsromans. Darmstadt: Wiss. Buchgesellschaft, 1988, pp. 64, 66 (Wege der Forshung, 640).

OVIEDO, José Miguel, "Reflexiones sobre e criollismo y su desarrollo en Chile.” In: Anales de Literatura Hispanoamericana, no 27, 1988, pp. 25-34.

PALMA, Daniel \& Fernández, Marcos. "Del delito al encierro. Vida carcelaria em Chile en el siglo XIX". In Historia de la vida privada en Chile. Sagredo, Rafael; Gazmuri, Cristián, Orgs. Santiago: Taurus, 2005.

PINTO, C. F. O Bildungsroman feminino: quatro exemplo brasileiros. São Paulo, Perspectiva, 1990. (Série debates - crítica).

PRIETO, Víctor Escudero. Reflexiones sobre el sujeto en el primer Bildungsroman. Master 'Construcción y representación de identidades culturales'. Departamento de Filología Románica. Directora: Nora Catelli. Universidad de Barcelona, 2007/2008.

PROUST, Marcel. No Caminho de Swann - tradução Mario Quintana. São Paulo: Editora Globo. 2006.

REY HAZAS, Antonio. La novela picaresca. Madrid: Anaya,1990.

ROSENFELD, Anatol. "Literatura e personagem". In A personagem de fiç̧ão. Candido, Antonio... São Paulo, Perspectiva 2011.

ROWE, William. "El criollismo". In América Latina - Palavra, Literatura e Cultura. Pizarro, Ana, (Org.) Campinas - São Paulo: Editora Unicamp, 1994, v. 2, p.713.

SCHOPENHAUER, Arthur. Da morte. Metafísica do amor. Do sofrimento do mundo. São Paulo: Martin Claret, 2001.

STAHL, E. L. Die Entstehung des deutschen Bildungsroman im achzehnten Jahrhundert. In: SELBMANN, R. (Ed.) Zur Geschichte des deutschen Bidungsromans. Darmstadt: Wiss. Buchgesellschaft, 1988, pp. 81-123.

SUBERCASEAUX, Bernardo. Historia de las ideas y de la cultura en Chile. Santiago: Editorial Universitaria, 1997.

TASENDE, Ana María Plata. Diccionario de términos literários. Madri: EspasaCalpe, 2007. 
VOSSKAMP, W. Gattung als literarisch-soziale Institutionen (Zu Problemen sozial - und funktionsgeschichtlich orientierter Gattungstheorie und - historie). HINCK, W. (Ed.) Textsortenlehre - Gattungsgeschichte. Heidelberg: Quelle \& Meyer, 1977.

WILDE, Oscar. "The Soul of Man Under Socialism" In: The Fortnightly Review, London, 1891, p. 9

WILLEMART, Philippe. Proust, Poeta e Psicanalista. São Paulo: Ateliê Editorial, 2000. 